\title{
Changes in Composition and Porosity 0ccurring During the Thermal Degradation of Wood and Wood Components
}

Scientific Investigations Report 2004-5292 



\section{Changes in Composition and Porosity Occurring During the Thermal Degradation of Wood and Wood Components}

By David W. Rutherford, Robert L. Wershaw, and Larry G. Cox

Scientific Investigations Report 2004-5292 


\section{U.S. Department of the Interior \\ Gale A. Norton, Secretary \\ U.S. Geological Survey \\ Charles G. Groat, Director}

U.S. Geological Survey, Reston, Virginia: 2005

For sale by U.S. Geological Survey, Information Services
Box 25286, Denver Federal Center
Denver, CO 80225
For more information about the USGS and its products:
Telephone: 1-888-ASK-USGS
World Wide Web: http://www.usgs.gov/

Any use of trade, product, or firm names in this publication is for descriptive purposes only and does not imply endorsement by the U.S. Government.

Although this report is in the public domain, permission must be secured from the individual copyright owners to reproduce any copyrighted materials contained within this report. 


\section{Contents}

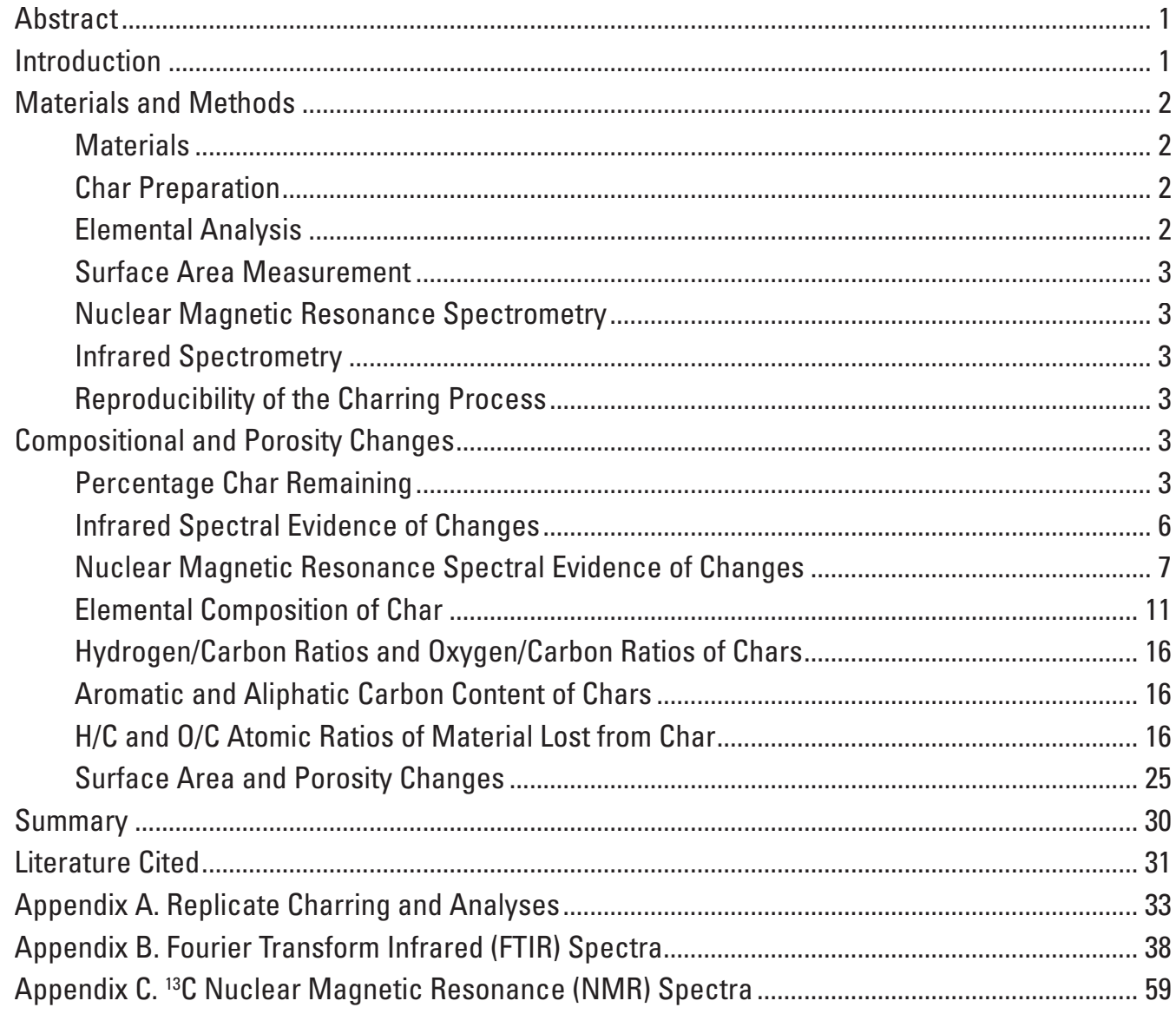

\section{Figures}

1-7. Graphs showing:

1. Percentage mass remaining (yield) for cellulose, lignin, poplar wood, pine wood, and pine bark after charring at $\boldsymbol{A}, 250^{\circ} \mathrm{C}, \boldsymbol{B}, 300^{\circ} \mathrm{C}$ and $\boldsymbol{C}, 350^{\circ} \mathrm{C}$ for various times.... 5

2. Chemical structures of cellulose and lignin monomeric units...................................... 9

3. Calculated aromatic and aliphatic carbon content (Grams Carbon/100 Grams Starting Material) in cellulose and cellulose char at various heating times and temperatures.

4. Calculated aromatic and aliphatic carbon content (Grams Carbon/100 Grams Starting Material) in lignin and lignin char at various heating times and temperatures.

5. Calculated aromatic and aliphatic carbon content (Grams Carbon/100 Grams Starting Material) in poplar wood and chars at various heating times and temperatures.

6. Calculated aromatic and aliphatic carbon content (Grams Carbon/100 Grams

Starting Material) in pine wood and chars at various heating times and temperatures. 


\section{Figures-Continued}

7. Calculated aromatic and aliphatic carbon content (Grams Carbon/100 Grams Starting Material) in pine bark and chars at various heating times and temperatures.

\section{Tables}

1. Percentage char remaining after heating.

2. ${ }^{13} \mathrm{C}$ NMR chemical shifts of cellulose and of guaiacylpropanoid and syringylpropanoid lignin units where $\mathrm{C}-4$ is linked by an ether linkage to another phenylpropanoid unit (data from Hassi and others, 1987) ............................................................ 8

3. Percentage aromatic carbon in chars after heating.................................................... 10

4. Percentage carbon remaining in char after heating, normalized to a dry and ash-free basis

5. Percentage hydrogen remaining in char after heating, normalized to a dry and ash-free basis

6. Percentage oxygen remaining in char after heating, determined by difference from ash, carbon and hydrogen content.

7. Hydrogen/carbon atomic ratios and oxygen/carbon atomic ratios of chars.

8. Grams of aromatic carbon or aliphatic carbon in char per 100 grams of starting material.

9. Hydrogen/carbon atomic ratios and oxygen/carbon atomic ratios of material lost

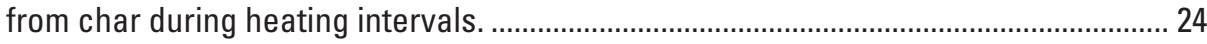

10. Micropore volume in char after heating.................................................................... 27

11. Total pore volume in char after heating.................................................................... 28

12. Surface area in char after heating.

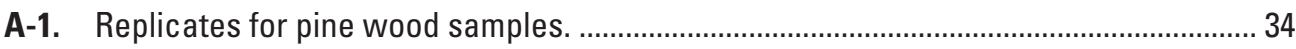

A-2. Replicates for pine bark samples. ………………..................................................... 35

A-3. Replicates for cellulose samples........................................................................... 36

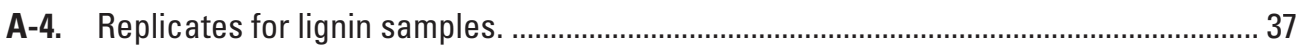

\section{Appendix figures}

B-1-C-21. Graphs showing:

B-1. Fourier Transform Infrared (FTIR) spectra of unheated cellulose, lignin, pine wood, poplar wood and pine bark.

B-2. Fourier Transform Infrared (FTIR) spectra of cellulose heated at $250^{\circ} \mathrm{C}$ for various times.

B-3. Fourier Transform Infrared (FTIR) spectra of cellulose heated at $300^{\circ} \mathrm{C}$ for various times.

B-4. Fourier Transform Infrared (FTIR) spectra of cellulose heated at $350^{\circ} \mathrm{C}$ for various times.

B-5. Fourier Transform Infrared (FTIR) spectra of cellulose heated at $400^{\circ} \mathrm{C}$ for various times.

B-6. Fourier Transform Infrared (FTIR) spectra of lignin heated at $250^{\circ} \mathrm{C}$ for various times. 


\section{Appendix figures-Continued}

B-7. Fourier Transform Infrared (FTIR) spectra of lignin heated at $300^{\circ} \mathrm{C}$ for various times.

B-8. Fourier Transform Infrared (FTIR) spectra of lignin heated at $350^{\circ} \mathrm{C}$ for various times.

B-9. Fourier Transform Infrared (FTIR) spectra of lignin heated at $400^{\circ} \mathrm{C}$ for various times.

B-10. Fourier Transform Infrared (FTIR) spectra of lignin heated at $500^{\circ} \mathrm{C}$ for various times.

B-11. Fourier Transform Infrared (FTIR) spectra of poplar wood heated at $250^{\circ} \mathrm{C}$ for various times.

B-12. Fourier Transform Infrared (FTIR) spectra of poplar wood heated at $300^{\circ} \mathrm{C}$ for various times.

B-13. Fourier Transform Infrared (FTIR) spectra of poplar wood heated at $350^{\circ} \mathrm{C}$ for various times.

B-14. Fourier Transform Infrared (FTIR) spectra of poplar wood heated at $400^{\circ} \mathrm{C}$ and $500^{\circ} \mathrm{C}$ for one hour.

B-15. Fourier Transform Infrared (FTIR) spectra of pine wood heated at $250^{\circ} \mathrm{C}$ for various times.

B-16. Fourier Transform Infrared (FTIR) spectra of pine wood heated at $300^{\circ} \mathrm{C}$ for various times.

B-17. Fourier Transform Infrared (FTIR) spectra of pine wood heated at $350^{\circ} \mathrm{C}$ for various times. 54

B-18. Fourier Transform Infrared (FTIR) spectra of pine wood heated at $400^{\circ} \mathrm{C}$, $500^{\circ} \mathrm{C}$, and $600^{\circ} \mathrm{C}$ for one hour. 55

B-19. Fourier Transform Infrared (FTIR) spectra of pine bark heated at $250^{\circ} \mathrm{C}$ for various times.

B-20. Fourier Transform Infrared (FTIR) spectra of pine bark heated at $300^{\circ} \mathrm{C}$ for various times.

B-21. Fourier Transform Infrared (FTIR) spectra of pine bark heated at $350^{\circ} \mathrm{C}$ for various times.

C-1. ${ }^{13} \mathrm{C}$ Nuclear Magnetic Resonance (NMR) spectra of unheated cellulose, lignin, pine wood, poplar wood and pine bark.

C-2. ${ }^{13} \mathrm{C}$ Nuclear Magnetic Resonance (NMR) spectra of cellulose heated at $250^{\circ} \mathrm{C}$ for various times

C-3. ${ }^{13} \mathrm{C}$ Nuclear Magnetic Resonance (NMR) spectra of cellulose heated at $300^{\circ} \mathrm{C}$ for various times

C-4. ${ }^{13} \mathrm{C}$ Nuclear Magnetic Resonance (NMR) spectra of cellulose heated at $350^{\circ} \mathrm{C}$ for various times.

C-5. ${ }^{13} \mathrm{C}$ Nuclear Magnetic Resonance (NMR) spectra of cellulose heated at $400^{\circ} \mathrm{C}$ for various times

C-6. ${ }^{13} \mathrm{C}$ Nuclear Magnetic Resonance (NMR) spectra of lignin heated at $250^{\circ} \mathrm{C}$ for various times.

C-7. ${ }^{13} \mathrm{C}$ Nuclear Magnetic Resonance (NMR) spectra of lignin heated at $300^{\circ} \mathrm{C}$ for various times.

C-8. ${ }^{13} \mathrm{C}$ Nuclear Magnetic Resonance (NMR) spectra of lignin heated at $350^{\circ} \mathrm{C}$ for various times. 


\section{Appendix figures-Continued}

C-9. ${ }^{13} \mathrm{C}$ Nuclear Magnetic Resonance (NMR) spectra of lignin heated at $400^{\circ} \mathrm{C}$ for various times.

C-10. ${ }^{13} \mathrm{C}$ Nuclear Magnetic Resonance (NMR) spectra of lignin heated at $500^{\circ} \mathrm{C}$ for various times.

C-11. ${ }^{13} \mathrm{C}$ Nuclear Magnetic Resonance (NMR) spectra of poplar wood heated at $250^{\circ} \mathrm{C}$ for various times.

C-12. ${ }^{13} \mathrm{C}$ Nuclear Magnetic Resonance (NMR)spectra of poplar wood heated at $300^{\circ} \mathrm{C}$ for various times.

C-13. ${ }^{13} \mathrm{C}$ Nuclear Magnetic Resonance (NMR) spectra of poplar wood heated at $350^{\circ} \mathrm{C}$ for various times.

C-14. ${ }^{13} \mathrm{C}$ Nuclear Magnetic Resonance (NMR) spectra of poplar wood heated at $400^{\circ} \mathrm{C}$ and $500^{\circ} \mathrm{C}$ for one hour.

C-15. ${ }^{13} \mathrm{C}$ Nuclear Magnetic Resonance (NMR) spectra of pine wood heated at $250^{\circ} \mathrm{C}$ for various times.

C-16. ${ }^{13} \mathrm{C}$ Nuclear Magnetic Resonance (NMR) spectra of pine wood heated at $300^{\circ} \mathrm{C}$ for various times.

C-17. ${ }^{13} \mathrm{C}$ Nuclear Magnetic Resonance (NMR) spectra of pine wood heated at $350^{\circ} \mathrm{C}$ for various times.

C-18. ${ }^{13} \mathrm{C}$ Nuclear Magnetic Resonance (NMR) spectra of pine wood heated at $400^{\circ} \mathrm{C}$, and $500^{\circ} \mathrm{C}$ for one hour.

C-19. ${ }^{13} \mathrm{C}$ Nuclear Magnetic Resonance (NMR) spectra of pine bark heated at $250^{\circ} \mathrm{C}$ for various times.

C-20. ${ }^{13} \mathrm{C}$ Nuclear Magnetic Resonance (NMR) spectra of pine bark heated at $300^{\circ} \mathrm{C}$ for various times.

C-21. ${ }^{13} \mathrm{C}$ Nuclear Magnetic Resonance (NMR) spectra of pine bark heated at $350^{\circ} \mathrm{C}$ for various times. 


\title{
Changes in Composition and Porosity Occurring During the Thermal Degradation of Wood and Wood Components
}

\author{
By David W. Rutherford, Robert L. Wershaw, and Larry G. Cox
}

\section{Abstract}

Samples of pine and poplar wood, pine bark, and purified cellulose and lignin were charred at temperatures ranging from $250^{\circ} \mathrm{C}$ to $500^{\circ} \mathrm{C}$ for times ranging from 1 hour to 168 hours. Changes in composition were examined by Fourier Transform Infrared (FTIR) and ${ }^{13} \mathrm{C}$ Nuclear Magnetic Resonance (NMR) spectrometry, mass loss, and elemental composition (carbon, hydrogen, and oxygen) of the char. Structural changes were examined by changes in porosity as measured by nitrogen gas adsorption. ${ }^{13} \mathrm{C}$ NMR spectrometry, mass loss, and elemental composition were combined to estimate the mass of aromatic and aliphatic carbon remaining in the char. Mass loss and elemental composition were combined to estimate the chemical composition of material lost for various time intervals of heating. These analyses showed that aliphatic components in the test materials were either lost or converted to aromatic carbon early in the charring process. Nitrogen adsorption showed that no porosity develops for any of the test materials with heating at $250^{\circ} \mathrm{C}$, even though substantial loss of material and changes in composition occurred. Porosity development coincided with the loss of aromatic carbon, indicating that micropores were developing within a fused-ring matrix.

\section{Introduction}

Pyrolytic carbon (the so-called black carbon fraction) is the least studied component of soil organic carbon (SOC). Black Carbon (BC) has been detected in many soils and sediments (Cambardella and Elliot, 1992; Karapanagiotti and others, 2000; Schmidt and others, 1999; Skjemstad and others, 1996; Skjemstad and others, 2002) and is probably present in most soils. Some workers have estimated that BC constitutes as much as 55 percent of SOC; however, it now appears that many of the estimates of the amount of BC in soils are too high (see Gelinas and others, 2001; Simpson and Hatcher, 2004b). Simpson and Hatcher (2004a,b), using a method that is much improved over previous methods, found that BC constituted 22.3 percent of the total organic carbon in a Canadian chernozem; they measured much lower values in other soils. Gelinas and others (2001) divided BC into two components: char/charcoal BC (CBC) and soot/graphitic BC (GBC).
The $\mathrm{CBC}$ fraction is formed by charring biomass of mainly plant origin, whereas the GBC fraction is formed by vaporphase reactions. Gelinas and others (2001) pointed out that GBC particles are much smaller than CBC particles, and that they are "**** rapidly dispersed through aerosol formation and atmospheric transport and deposition." The CBC particles, on the other hand, generally will remain in the soil near where they are produced. In this report we shall be concerned only with the $\mathrm{CBC}$ fraction.

$\mathrm{BC}$ can markedly alter the physical chemical properties of soils. For example, Glaser and others (2001) demonstrated that $\mathrm{BC}$ is crucial in maintaining fertility of the so-called "terra preta" black soils of the Amazon Basin of Brazil. These soils occur in relatively small, isolated sites averaging about 20 hectares (ha) in area. The sites generally are surrounded by highly leached oxisols of low fertility. The presence of charcoal $(\mathrm{CBC})$ in the terra preta soils differentiates them from the surrounding oxisols. This charcoal possibly was formed by campfires and incorporated into the terra preta soils by native Indian farmers prior to the arrival of Europeans in the New World and has persisted until the present. The presence of the CBC greatly increases the capacity of these soils to bind nutrients such as nitrogen, phosphorus, calcium, and potassium; $\mathrm{pH}$ values and water-holding capacities also are enhanced. In addition to the binding of inorganic constituents, BC strongly binds hydrophobic organic compounds. $\mathrm{BC}$ has a much higher sorption capacity for hydrophobic organics than other SOC components (Karapanagiotti and others, 2000).

The physical chemical properties of activated carbons have been extensively studied; however, it is likely that the properties of soil $\mathrm{CBC}$ will be substantially different from those of activated carbon. Activated carbons are generally prepared at high temperatures in the presence of activating agents such as steam (Patrick, 1995). Soil CBC, on the other hand, is generally produced at much lower temperatures by forest or grass fires or, in the case of the terra preta soils, by campfires. No comprehensive studies have been conducted on the properties of charcoals produced at low temperatures from biomass.

The compositional changes occurring during the charring of cellulose, lignin, and wood have been studied previously (Shafizadeh, 1982; Pastorova and others, 1994; Amen-Chen and others, 2001; González-Vila and others; 2001). Williams and Besler (1996) found that under slow pyrolysis, hemicellulose and cellulose begin decomposition at $250^{\circ}$ Celsius (C) 
with the majority of weight loss by $400^{\circ} \mathrm{C}$. Lignin showed more gradual weight loss from $200^{\circ} \mathrm{C}$ to $720^{\circ} \mathrm{C}$. Baldock and Smernik (2002) used solid-state ${ }^{13} \mathrm{C}$ nuclear magnetic resonance (NMR), diffuse-reflectance infrared (IR), and elemental analysis to study the composition changes brought about by the charring of red pine wood at different temperatures. In all of their experiments, the wood was heated at a given temperature for 24 to 72 hours until a constant mass of residual char was obtained. No short-term heating experiments were conducted, and they did not measure the surface areas of the chars.

Surface area is a particularly important parameter to measure because the sorption and ion exchange properties of charcoals are directly related to surface area. Surface areas of charcoal can vary from 1 square meter $\left(\mathrm{m}^{2}\right) / \mathrm{gram}(\mathrm{g})$ to $500 \mathrm{~m}^{2} / \mathrm{g}$. The creation of high surface area, as measured by the nitrogen-sorption Brunauer, Emmett, and Teller (BET) method (see Brunauer and others, 1938), is related to the creation of micropores; that is, pores with diameters less than 2 nanometers $(\mathrm{nm})$. Porous carbons have been modeled as being composed of aggregates of fused-ring carbon structures that form small lamellar crystallites. The structure of the crystallites is similar to that of graphite; however, ordering is of much shorter range than in graphite (Byrne and Marsh, 1995; Jorge and others, 2002). The creation of pores in charcoal is not well understood, but it has been related to heating temperature and duration of heating. Improved understanding of composition and porosity of charcoal has application to studies of the environmental effects of black carbon in soils, either from natural causes such as forest fires or from the use of charcoal as a soil amendment for agricultural purposes.

This report provides the results of changes in composition (measured by char yield, elemental composition, NMR, and IR) and changes in structure (measured by porosity) made on chars produced in the laboratory from cellulose, lignin, pine and popular wood, and pine bark under controlled conditions of temperature and heating duration. Chars were prepared under nitrogen to eliminate combustion so that temperature could be controlled and a reproducible char produced. Thus, comparisons of the physical and chemical changes brought about in different materials due to variations in heating temperature and duration can be made.

\section{Materials and Methods}

\section{Materials}

Cellulose was obtained commercially as a microcrystalline powder (approximately 20 micrometer $(\mu \mathrm{m})$ particle size) and had been purified from wood pulp. The Organosolv lignin was obtained commercially as a powder that had been extracted from mixed hardwoods by the Organosolv process (Allan, 1971, p. 540-541).
The pine samples were obtained from a cross-section of ponderosa pine log (Pinus ponderosa). Pine bark material was collected and treated separately. The wood was shredded with a hand-held electric plane. The shavings were 1 millimeter $(\mathrm{mm})$ or less in thickness, 2 to $4 \mathrm{~mm}$ in width, and 1 centimeter $(\mathrm{cm})$ or less in length. Wood samples were air-dried prior to use. The bark was air-dried and ground using a hand mill.

The poplar samples were obtained from a hardwood board procured at a local lumberyard (exact species unknown). The material was shredded on a lathe. The shavings were $1 \mathrm{~mm}$ or less in thickness, 2 to $5 \mathrm{~mm}$ in width, and 2 to $5 \mathrm{~mm}$ in length. Samples were air-dried prior to use.

\section{Char Preparation}

Char was prepared by weighing the shredded or powdered sample into 250 milliliter $(\mathrm{mL})$ porcelain crucibles. The crucibles were heated without tops with between 10 and 20 grams (g) of material per crucible. The crucibles were placed in a preheated muffle furnace with nitrogen flow sufficient to produce three air changes per minute within the furnace. The nitrogen used was ultra high purity (UHP) grade with less than 1 parts per million (ppm) oxygen. After heating, crucibles were placed in a nitrogen-filled desiccator to cool to room temperature. The percentage yield was determined by weighing samples before and after heating. The char was then pulverized with a mortar and pestle.

\section{Elemental Analysis}

Carbon and hydrogen were determined by combustion in oxygen at $1000^{\circ} \mathrm{C}$; the combustion products were passed through catalysts to ensure complete oxidation. Water was trapped, and carbon dioxide $\left(\mathrm{CO}_{2}\right)$ was measured with a $\mathrm{CO}_{2}$ coulometer. Water was then released from its trap and quantitatively converted to $\mathrm{CO}_{2}$ and measured by a second coulometer. Moisture was determined by loss on drying at $105^{\circ} \mathrm{C}$ overnight. Ash content was determined by combustion in air at $750^{\circ} \mathrm{C}$. Carbon, hydrogen, and ash were converted to a dry-weight basis. Oxygen was determined by difference. All results reported for carbon, hydrogen, and ash have been normalized to an ash-free basis. Where ash was not determined directly (21 samples out of 81 samples), an estimate was made on the basis of the percentage mass remaining by using a power function numerical fit in the form:

$$
\text { percentage ash }=\mathrm{A}(\text { percentage mass remaining })^{\mathrm{B}} .
$$


The following results from the numerical fit were obtained:

\begin{tabular}{lccc}
\hline & A & B & $\begin{array}{c}\text { Correlation } \\
\text { coefficient }\left(\mathbf{R}^{2}\right)\end{array}$ \\
\hline Pine wood & 24.5 & -0.905 & 0.88 \\
Poplar wood & 23.2 & -0.887 & 0.98 \\
Pine bark & 235 & -0.956 & 0.98 \\
\hline
\end{tabular}

\section{Surface Area Measurement}

The surface area was determined by adsorption of nitrogen $\left(\mathrm{N}_{2}\right)$ at liquid nitrogen temperature by using an automated surface area analyzer. The samples were out-gassed by heating at $110^{\circ} \mathrm{C}$ under a flow of ultrahigh purity helium at 10 cubic centimeters $\left(\mathrm{cm}^{3}\right) /$ minute (min) for 16 to 24 hours (hr) prior to analysis. Isotherm data were recorded at partial pressures of nitrogen between 0.05 and 0.95 atmospheres. The apparent surface areas of samples were obtained from the statistical monolayer capacities of $\mathrm{N}_{2}$ from the BET plots (Brunauer and others, 1938). The micropore volumes were determined by the $t$-method of de Boer and others (1966).

\section{Nuclear Magnetic Resonance Spectrometry}

Solid-state ${ }^{13} \mathrm{C}$ NMR spectra of the charcoals were measured on a Chemagnetics CMX 200-megahertz (MHz) proton frequency spectrometer (Wershaw and others, 1998) equipped with a $7.5-\mathrm{mm}$ Chemagnetics ceramic probe. The samples were packed in zirconia rotors and spun at 5,000 hertz $(\mathrm{Hz})$. The acquisition parameters were contact time of 1 millisecond (ms) or $5 \mathrm{~ms}$, pulse delay of 1 second (s), and 4.5 microsecond $(\mu \mathrm{s}) 90^{\circ}$ pulse.

\section{Infrared Spectrometry}

Infrared spectra were collected by using 2 to 5 milligrams $(\mathrm{mg})$ of sample in a potassium bromide $(\mathrm{KBr})$ pellet. The Perkin Elmer System 2000 Fourier Transform Infrared (FTIR) used an infrared source with a pulsed laser carrier and a deuterated triglycine sulfate detector. The instrument was scanned from 4,000 to 400 reciprocal centimeters $\left(\mathrm{cm}^{-1}\right)$, averaging 10 scans at $1.0 \mathrm{~cm}^{-1}$ intervals with a resolution of $4.0 \mathrm{~cm}^{-1}$. All spectra were normalized after acquisition to a maximum absorbance of 1.0 for comparison purposes.

\section{Reproducibility of the Charring Process}

Selected raw materials were charred four or five times at the same temperature and time to evaluate the reproducibility of the charring process. For each replicate at a given time and temperature, the percentage char remaining, surface area, and total pore volume were measured. These data are presented in appendix A.
The char composition, based on percentage char remaining, was very reproducible. The percentage char remaining ranged from 60.2 to 13.9 percent with standard deviations ranging from 4.26 to 0.56 percent. The median yield was 32.9 percent with a median standard deviation of 1.90 percent.

The reproducibility of char structure, based on total pore volume, was more variable than compositional changes. The total pore volume ranged from 0.240 to $0.001 \mathrm{~cm}^{3}$ with standard deviations ranging from 0.039 to $0.0002 \mathrm{~cm}^{3}$. The median total pore volume was $0.034 \mathrm{~cm}^{3}$ with a median standard deviation of $0.0048 \mathrm{~cm}^{3}$. The data show that there are three populations of pore volumes. The population with little or no pore volumes was near the detection level, and standard deviations ranged from 10 to 100 percent of the average. When pore volumes began to increase, standard deviations ranged from 30 to 70 percent of the average. At higher temperatures and longer charring times, which resulted in higher pore volumes, standard deviations ranged from 10 to 30 percent of the average.

\section{Compositional and Porosity Changes}

\section{Percentage Char Remaining}

The percentage char remaining from cellulose, lignin, poplar and pine wood, and pine bark for various heating times and temperatures are listed in table 1 . The yield of char is a useful measurement of the total decomposition and volatilization of material from a sample.

When heated to $250^{\circ} \mathrm{C}$ for 1 hour, cellulose showed little weight loss ( 6.4 percent), but lost about 60 percent of its weight when heated for 8 hours. Weight loss continued with time, though more gradually, with 68.6 percent lost after 72 hours heating (fig. 1a). When heated at $300^{\circ} \mathrm{C}$, cellulose lost 66.7 percent of its weight after 1 hour, 69.1 percent after 8 hours, and 72.8 percent after 24 hours (fig. 1b). Increased temperature caused increased weight loss with most of the weight loss occurring in the first hour of heating (fig. 1c).

With heating at $250^{\circ} \mathrm{C}$, lignin lost 15.3 percent of its weight after 24 hours and 20 percent after 144 hours. When heated at $300^{\circ} \mathrm{C}$ for 24,48 and 72 hours, the weight losses were 32.4 percent, 36.3 percent, and 40.7 percent, respectively. Higher temperatures increased the rate of weight loss with 80 to 85 percent loss after 24 hours at $400^{\circ} \mathrm{C}$ and 8 hours at $500^{\circ} \mathrm{C}$. For comparable temperatures and times, lignin weight loss was consistently less than half that of cellulose.

At $250^{\circ} \mathrm{C}$ and $300^{\circ} \mathrm{C}$, both pine and poplar wood showed weight losses nearly identical to cellulose. At $350^{\circ} \mathrm{C}$, the weight loss from both species of wood exceeded that of cellulose for heating times greater than 8 hours. Pine and poplar wood were reduced to ash after 48 hours. For all heating conditions, the yield of char for both woods was less than what would have been expected on the basis of estimates of the char remaining from cellulose and lignin components of 
wood. This could be the result of reaction between degradation products in the mixture or could result from a catalytic effect of the ash components, which became more concentrated in the wood char as weight loss progressed. The inert gas used in the oven was nitrogen produced from the boil off of liquid nitrogen, with an oxygen content of less than $1 \mathrm{ppm}$. The small amount of oxygen in the nitrogen gas could account for some of the continued loss of weight observed for long heating times.

Pine bark exhibited a similar exponential decrease in mass with heating time as the wood samples but had 5 to 10 percent higher char yield at all times and temperatures, except for heating for one hour at $250^{\circ} \mathrm{C}$; the char yield for bark was slightly lower than for wood.

Table 1. Percentage char remaining after heating.

$\left[{ }^{\circ} \mathrm{C}\right.$, degrees Celsius; --, no data]

\begin{tabular}{|c|c|c|c|c|c|}
\hline \multirow[b]{2}{*}{ Time (hours) } & \multicolumn{5}{|c|}{ Preparation temperatures } \\
\hline & $250^{\circ} \mathrm{C}$ & $300^{\circ} \mathrm{C}$ & $350^{\circ} \mathrm{C}$ & $400^{\circ} \mathrm{C}$ & $500^{\circ} \mathrm{C}$ \\
\hline \multicolumn{6}{|c|}{ Cellulose } \\
\hline 1 & 93.6 & 33.3 & 27.8 & 22.3 & -- \\
\hline 8 & 44.1 & 30.7 & 23.5 & -- & -- \\
\hline 24 & 35.5 & 27.2 & 18.9 & 7.8 & -- \\
\hline 48 & 34.7 & 23.9 & 12.8 & -- & -- \\
\hline 72 & 31.4 & 22.2 & 9.02 & -- & -- \\
\hline \multicolumn{6}{|c|}{ Lignin } \\
\hline 1 & -- & 76.8 & 64.3 & 51.8 & 38.9 \\
\hline 8 & -- & 70.0 & 55.3 & 38.2 & 19.1 \\
\hline 24 & 84.7 & 67.8 & 41.2 & 15.6 & -- \\
\hline 48 & -- & 63.7 & 32.8 & -- & -- \\
\hline 72 & 80.6 & 59.3 & 23.9 & -- & -- \\
\hline 144 & 80.0 & -- & -- & -- & -- \\
\hline \multicolumn{6}{|c|}{ Poplar wood } \\
\hline 1 & 75.9 & 41.6 & 27.1 & 22.9 & 16 \\
\hline 8 & 42.5 & 27.8 & 20.4 & -- & -- \\
\hline 24 & 38.3 & 21.8 & 11.3 & -- & -- \\
\hline 48 & -- & 18.5 & 3.1 & -- & -- \\
\hline 72 & 33.0 & 15.7 & 0.65 & -- & -- \\
\hline 144 & 29.7 & -- & -- & -- & -- \\
\hline \multicolumn{6}{|c|}{ Pine wood } \\
\hline 1 & 79.2 & 42.4 & 26.8 & 22.5 & 11.2 \\
\hline 8 & 55.8 & 32.9 & 21.1 & -- & -- \\
\hline 24 & 43.3 & 25.1 & 5.1 & -- & -- \\
\hline 48 & 36.2 & 19.9 & 0.65 & -- & -- \\
\hline 72 & -- & 17.2 & 0.34 & -- & -- \\
\hline 168 & 30.2 & -- & -- & -- & -- \\
\hline \multicolumn{6}{|c|}{ Pine bark } \\
\hline 1 & 73.3 & 53.7 & 44.5 & -- & -- \\
\hline 8 & 60.2 & 47.5 & 33.3 & -- & -- \\
\hline 24 & 51.9 & 35.5 & 19.5 & -- & -- \\
\hline 48 & -- & 24.3 & 9.1 & -- & -- \\
\hline 72 & 42.7 & 18.1 & -- & -- & -- \\
\hline 168 & 34.3 & -- & -- & -- & -- \\
\hline
\end{tabular}



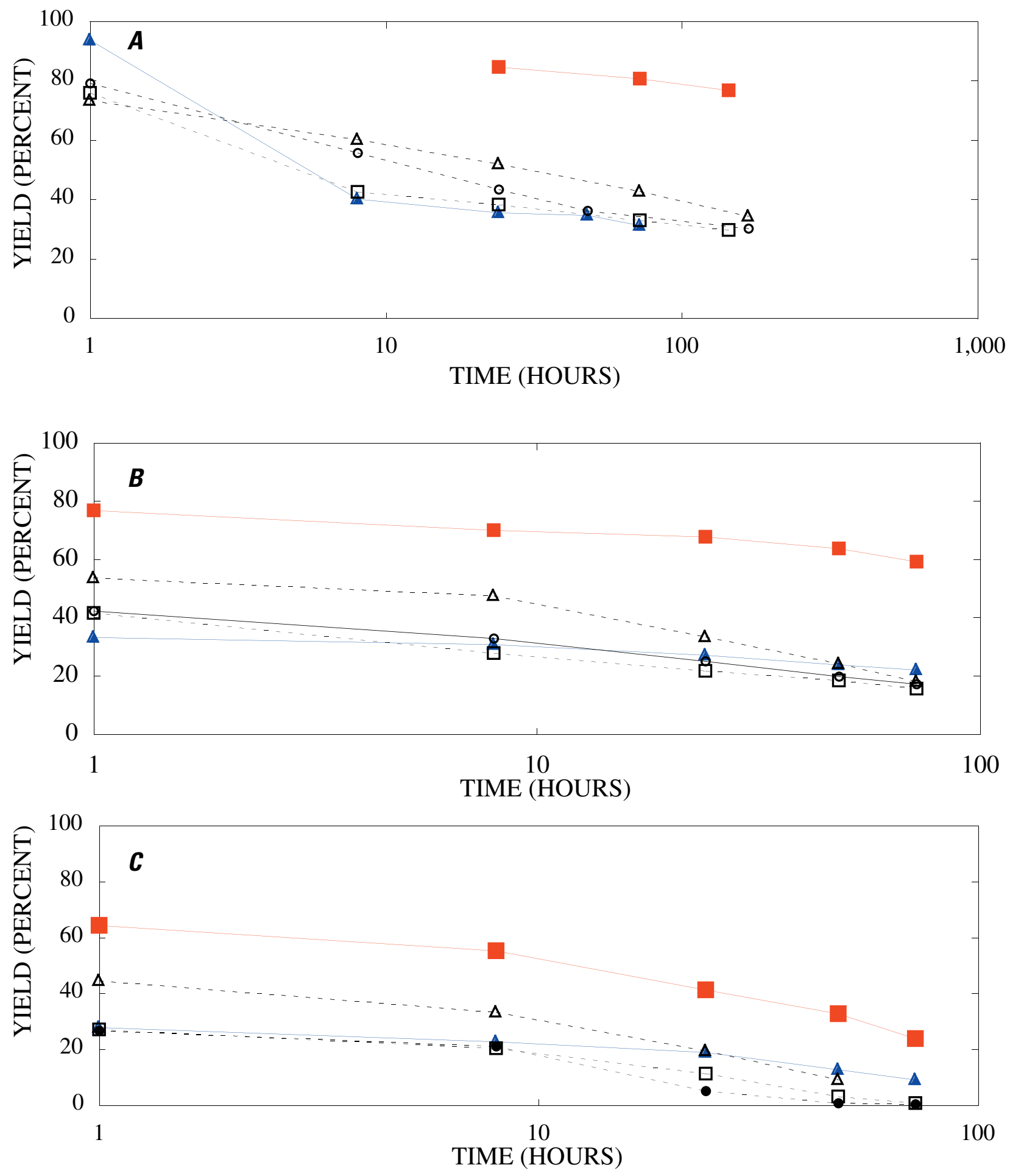

\section{EXPLANATION}

$\triangle$ Cellulose —— Lignin - - $\square$ - - Poplar Wood - . - - Pine Wood - . - - - Pine Bark

Figure 1 [a-c]. Percentage mass remaining (yield) for cellulose, lignin, poplar wood, pine wood, and pine bark after charring at $A, 250^{\circ} \mathrm{C}, \boldsymbol{B}, 300^{\circ} \mathrm{C}$ and $\boldsymbol{C}, 350^{\circ} \mathrm{C}$ for various times. 


\section{Infrared Spectral Evidence of Changes}

The FTIR spectra of the unheated wood samples consist mainly of bands that may be attributed to carbohydrates (cellulose and hemicellulose) and lignin. To follow more easily the chemical changes that take place during the pyrolysis of wood, the changes that occur when pure cellulose and lignin are pyrolyzed will be examined first. The most prominent carbohydrate bands in the unheated cellulose were between 1,000 and $1,200 \mathrm{~cm}^{-1}$ (figure B-1, appendix B). These bands at $1,035,1,060,1,110$, and $1,159 \mathrm{~cm}^{-1}$ are essentially in the same positions as those observed by Chen and Jakes (2002) in the IR spectra of single cotton fibers. The major lignin bands are shown in figure B-1, appendix B. Faix (1991) has identified diagnostic lignin bands at approximately 1,221, 1,269, 1,326, $1,367,1,423,1,464,1,510$, and $1,596 \mathrm{~cm}^{-1}$. In addition, there are lignin bands at 1,035, 1,086, 1,140, and $1,166 \mathrm{~cm}^{-1}$ (Faix, 1991); however, these bands are obscured in wood by the much stronger carbohydrate bands.

The FTIR spectra of cellulose heated to $250^{\circ} \mathrm{C}$ for different time intervals are given in appendix B, figure B-2. Heating to $250^{\circ} \mathrm{C}$ for 1 hour caused no discernable alteration of the cellulose spectrum. However, heating for 8 hours caused all of the characteristic cellulose bands to disappear. They have been replaced by broad bands centered at about 1,240, 1,435, 1,610, and $1,720 \mathrm{~cm}^{-1}$. At higher temperatures, these same bands were observed after shorter heating times (see figures B-3 to B-5 in Appendix B). In contrast, heating of lignin for different time intervals at $250^{\circ} \mathrm{C}$ only causes some broadening of the IR bands and a concomitant loss of resolution (appendix B, figure B-6). At higher temperatures the lignin bands coalesce into broad bands that were at similar positions to those observed in the 8 -hour $250^{\circ} \mathrm{C}$ cellulose spectrum (see figures B-7 to B-10 in appendix B).

Four bands at very similar positions to the four major bands in the spectrum of cellulose were present in the pine and poplar wood spectra. Heating the wood to $250^{\circ} \mathrm{C}$ for 1 hour increases the resolution of these bands (appendix B, figures B-11 and B-15). This increased resolution was not observed when pure cellulose was heated (appendix B, figure B-2), and therefore, it is probably due to drying and partial decomposition of the hemicelluloses that would be expected to have bands in slightly different positions than crystalline cellulose. Further heating of the wood at $250^{\circ} \mathrm{C}$ (from 8 to 168 hours) causes a continuous reduction in the relative intensities of the cellulose bands as the carbohydrate material decomposes.

The diagnostic lignin bands in the region between 1,200 and $1,600 \mathrm{~cm}^{-1}$ are present in the FTIR spectra of the unheated wood and 1 -hour $250^{\circ} \mathrm{C}$ samples. Further heating at $250^{\circ} \mathrm{C}$ causes a slight broadening of the bands. At higher temperatures, much more broadening of the bands is observed, and many of the bands coalesce. A prominent band at about $1,600 \mathrm{~cm}^{-1}$ develops at the higher temperatures. This band probably represents skeletal vibrations of fused-ring aromatic structures (see discussion of NMR data in the next section). In as much as the longer heating intervals at $250^{\circ} \mathrm{C}$ only slightly altered the FTIR spectra of the pure lignin, it is likely that the broadening observed in the wood spectra at $250^{\circ} \mathrm{C}$ is due to overlap of charred cellulose bands.

The bands in the FTIR spectrum of unheated pine bark (appendix B, figure B-1) are in the same positions as those of the unheated pine wood; however, the relative intensities of the bands are different. The ratio of the intensities of the lignin bands to the intensities of carbohydrate bands is larger in the bark than in the wood, indicating that the concentration of lignin is higher in the bark than in the wood. Heating of the bark brought about changes similar to those observed in the wood samples.

The heating experiments for different lengths of time at $250^{\circ} \mathrm{C}$ show the sequence of decomposition of the carbohydrate and lignin components in wood and bark. The 1-hour heating at $250^{\circ} \mathrm{C}$ has caused a substantial diminution of the cellulose bands in the FTIR spectra relative to the lignin bands; however, the carbohydrate spectral bands are better resolved. These results most likely indicate decomposition of the hemicellulose in the wood and bark. Heating at $250^{\circ} \mathrm{C}$ for 8 hours caused further diminution of the FTIR carbohydrate bands of the wood and bark samples and broadening of the bands. The heating for eight hours apparently caused decomposition of cellulose in addition to hemicellulose. Further heating of the wood and bark samples caused the aromatic band to grow at the expense of the other bands, and indicates an increase in fused-ring aromatic structures. Recognizable lignin and cellulose bands were still present in the 8-hour FTIR spectra; however, upon further heating FTIR bands coalesce into broad peaks. The broad bands centered near $1,600 \mathrm{~cm}^{-1}$, $1,430 \mathrm{~cm}^{-1}$, and in the region between 1,200 and $1,260 \mathrm{~cm}^{-1}$, probably arise from different types of aromatic structures. Quinones and quinone methide have strong bands in the 1,600 $\mathrm{cm}^{-1}$ region, and phenols absorb in the region between 1,200 and $1,260 \mathrm{~cm}^{-1}$ (Colthup and others, 1990).

Bands between 1,700 and $1,850 \mathrm{~cm}^{-1}$ in the IR spectra of the charred cellulose, lignin, wood, and bark probably represent different types of carbonyl carbons. The charred cellulose has bands at about 1,750,1,772, and $1,840 \mathrm{~cm}^{-1}$, whereas the charred lignin only has a band at about $1,717 \mathrm{~cm}^{-1}$ (appendix A, figure A-6). The strong band at $1,772 \mathrm{~cm}^{-1}$ and the weaker band at $1,840 \mathrm{~cm}^{-1}$ in the cellulose spectrum fit the pattern observed in five-membered ring cyclic anhydrides (Colthup and others, 1990). The band at $1,750 \mathrm{~cm}^{-1}$ probably represents five- or six-membered ring lactones. The band at $1,717 \mathrm{~cm}^{-1}$ in the charred lignin spectrum probably represents carboxylic acid groups. Pradhan and Sandle (1999) have shown that charcoal oxidized with nitric acid has a IR band at $1,719 \mathrm{~cm}^{-1}$; a careful examination of the IR spectra of their samples before and after oxidation led them to conclude that this band represents carboxylic acid groups attached to graphitic carbon atoms.

Spectra for charring at higher temperatures are available in appendix B (figs. B-12 to B-21). Except for lignin, which does not appear to fully decompose at $250^{\circ} \mathrm{C}$, increasing the charring temperature above $250^{\circ} \mathrm{C}$ for the other components 
only shortened the time required to produce a spectrum of completely charred material.

\section{Nuclear Magnetic Resonance Spectral Evidence of Changes}

The NMR spectra of unheated cellulose and cellulose heated to $250^{\circ} \mathrm{C}$ for different time intervals are shown in appendix $\mathrm{C}$, figure $\mathrm{C}-2$. All of the major cellulose bands with the exception of the anomeric carbon band $(\mathrm{C}-1)$ are well separated from the major lignin bands (table 2). The C-4 carbon for cellulose (fig. 2) is actually represented by two bands in our spectra, one at about $84 \mathrm{ppm}$ and one at about $88 \mathrm{ppm}$. Larsson and others (1999) have shown that the 88 ppm band represents crystalline or paracrystalline cellulose, and the 84 ppm band, less well-ordered cellulose. The spectrum of cellulose heated for 1 hour at $250^{\circ} \mathrm{C}$ is essentially the same as that of the unheated cellulose (appendix C, fig. C-2). After 8 hours of heating, the major cellulose bands have been replaced by a series of broad bands centered at about 25 , 70,127 , and $210 \mathrm{ppm}$. A shoulder at about $150 \mathrm{ppm}$ also is present. The most probable assignments for these bands are: 25 ppm, aliphatic hydrocarbon groups; 70 ppm, aliphatic alcohols; 127 ppm, fused-ring aromatic structures; and 210 ppm, ketones or aldehydes. Pastorova and others (1994) found that heating of cellulose to $250^{\circ} \mathrm{C}$ for 2.5 hours in a stream of nitrogen produced a new polymer that consisted of "*** furanoid skeletons, hydroxyaromatic skeletons, unsaturated hydrocarbon chains, and a high number of carboxyl and carbonyl carbons." When they heated the cellulose to $310^{\circ} \mathrm{C}$ for 2.5 hours condensed aromatic polymers formed. They also detected aliphatic structures and residual carbohydrate polymers.

Heating of cellulose at temperatures higher than $250^{\circ} \mathrm{C}$ caused a very rapid loss of the characteristic cellulose bands and the appearance of a broad band at about $127 \mathrm{ppm}$, representing fused-ring aromatic structures (figs. C-3 to C-5 in appendix C). A shoulder at about $152 \mathrm{ppm}$ in the 1-hour and 8 -hour $300^{\circ} \mathrm{C}$ spectra may represent phenolic structures. The band at about 158 ppm first seen in the 24 -hour $300^{\circ} \mathrm{C}$ spectrum probably represents benzofuranyl structures (see Pastorova and others, 1994, for possible examples). This band also is observed in the 8 -hour and 24 -hour $350^{\circ} \mathrm{C}$ spectra and in both the $400^{\circ} \mathrm{C}$ spectra.

The spectrum of unheated lignin is shown in appendix $\mathrm{C}$, figure C-1. A generalized lignin structural diagram is shown in figure 2, and the chemical shifts of the different carbon atoms in lignin polymers are given in table 2 . The spectrum of this organosolve lignin has a sharp band at about $148 \mathrm{ppm}$ and a much weaker band between 150 and 151 ppm. The constituent units of this lignin, therefore, are mainly guaiacylpropanoid units. Heating of the lignin at $250^{\circ} \mathrm{C}$ for up to 72 hours only causes a broadening of the spectral bands (appendix $\mathrm{C}$, figure C-6). Much more alteration of the lignin structure is apparent on heating to $300^{\circ} \mathrm{C}$ for 24 hours. The bands between 100 and 140 ppm have coalesced into a single band at about
127 ppm that probably represents fused-ring aromatic structures. The shift of the $148 \mathrm{ppm}$ band to about $145 \mathrm{ppm}$ is indicative of cleavage of the B-O-4 ether linkages. The band at about $55 \mathrm{ppm}$ in the spectrum of the heated lignin indicates that the methyl-ether linkages have largely survived the heating to $300^{\circ} \mathrm{C}$ for 24 hours. In addition, there is a very broad band centered at about $30 \mathrm{ppm}$ in the heated lignin spectrum; this band probably represents a variety of aliphatic structures.

Similar conclusions can be drawn from the changes observed in the carbohydrate and lignin bands of the heated wood NMR spectra (appendix C, figures C-11 to C-18). The positions of the bands observed in the carbohydrate regions of the ground woods and the woods heated for 1 hour at $250^{\circ} \mathrm{C}$ match those of cellulose. Lignin is represented by well-defined bands at 56, 134, and $148 \mathrm{ppm}$ in the unheated pine spectrum and at 56, 137, and $154 \mathrm{ppm}$ in the unheated poplar spectrum. The 148 ppm band in the pine spectrum has a shoulder at about $154 \mathrm{ppm}$, and the $154 \mathrm{ppm}$ band in the popular spectrum has a shoulder at about $148 \mathrm{ppm}$. In addition, there is a broad band between 110 and $125 \mathrm{ppm}$ in the pine spectrum that is probably due to lignin. Assignments for guaiacylpropanoid and syringylpropanoid bands are given in table 2. As indicated in the table, the 148 ppm band most likely represents guaiacylpropanoid units, and the 154 ppm band, syringylpropanoid units.

The bands between 50 and 180 ppm in the NMR spectrum of the unheated pine bark have similar chemical shifts to those in the unheated pine wood; however, the lignin bands are more intense in the bark than in the wood. The higher concentration of lignin in the bark than in the wood evidenced by the FTIR and NMR is probably indicative of cell-wall thickening in the bark. This secondary cell-wall thickening is probably similar to that which takes place in the compression wood of conifers (Croteau and others, 2000). When the wood is subjected to unusual compressional stress, the cell walls are thickened by addition of lignin, which provides additional compressional strength. In the case of the bark, the cell-wall thickening is necessary to reduce water loss from the vascular organs (xylem and phloem) of the living tissue of the tree that is located behind the outer bark.

In addition to the lignin and carbohydrates bands, two relatively weak bands at about 20 and $30 \mathrm{ppm}$ are present in the bark spectrum. The band at $30 \mathrm{ppm}$ is most likely due to suberin (Gil and others, 1997). Suberin is a polyester material that is found in the bark and underground parts of higher plants. Suberin also is secreted by plants to cover wounds. The band at about $20 \mathrm{ppm}$ is mostly due to terminal methyl groups.

As in the case of the carbohydrate bands in the FTIR spectra, heating of the wood and bark samples to $250^{\circ} \mathrm{C}$ causes an increase in resolution of the carbohydrate bands in the NMR spectra. A major change is observed in the lignin portion of the spectra with the disappearance of the $154 \mathrm{ppm}$ band and a concomitant increase in intensity of the $148 \mathrm{ppm}$ band. Haw and Schultz (1985) observed a similar behavior when they heated lignin to $250^{\circ} \mathrm{C}$. They attributed the changes to cleavage of $\mathrm{B}-\mathrm{O}-4$ ether linkages of syringylpropanoid units. 
The chemical shifts of the C-3 and C-5 carbon atoms change from about $154 \mathrm{ppm}$ to $148 \mathrm{ppm}$ when the ether linkage is replaced by an $\mathrm{OH}$ group. The corresponding shift for the C-3 and C-4 carbons of guaiacylpropanoid units is only about 2 ppm from about $148 \mathrm{ppm}$ to about $146 \mathrm{ppm}$. The resolution of the spectra in this region is not sufficient to see this shift. It is likely that the broad band observed at about $148 \mathrm{ppm}$ in the woods heated to $250^{\circ} \mathrm{C}$ represents both guaiacylpropanoid and syringylpropanoid units in which the $\mathrm{B}-\mathrm{O}-4$ ether linkages have been cleaved. The B-O-4 ether bonds account for at least 50 percent of the polymer linkages in most lignins (ten Have and Teunissen, 2001); and therefore, cleavage of these bonds results in substantial depolymerization of lignin.

The first step in the formation of the graphite-like crystallites is the development of fused-ring aromatic structures in the char. A useful index of the concentration of fused-ring aromatic carbon may be obtained by integration of the spectral regions of the NMR spectra. The regions integrated were chemical shifts from 0 to $110 \mathrm{ppm}, 110$ to $180 \mathrm{ppm}$, and 220 to $260 \mathrm{ppm}$. The spinning side bands of the aromatic bands appear in the region of chemical shifts from 0 to $40 \mathrm{ppm}$ and 220 to $260 \mathrm{ppm}$. The spinning side band in the region from 0 to 40 ppm cannot be distinguished from aliphatic bands in the same region. The area indicative of aliphatic components has been calculated by subtracting the area of the integration for 220 to $260 \mathrm{ppm}$ from the area of the integration for 0 to $110 \mathrm{ppm}$. This assumes that the spinning side bands are symmetrical and that the region of chemical shifts from 220 to $260 \mathrm{ppm}$ is due solely to spinning side band. The area indicative of aromatic components is corrected by adding twice the area of the integration for 220 to $260 \mathrm{ppm}$ to the area of the integration for 110 to $180 \mathrm{ppm}$. The percentage aromatic carbon shown in table 3 was computed by dividing the aromatic area by the sum of the aliphatic and aromatic area.

Table 2. ${ }^{13} \mathrm{C}$ NMR chemical shifts of cellulose and of guaiacylpropanoid and syringylpropanoid lignin units where C-4 is linked by an ether linkage to another phenylpropanoid unit (data from Hassi and others, 1987).

[ppm, parts per million]

\begin{tabular}{|c|c|c|c|c|c|}
\hline \multicolumn{2}{|c|}{$\begin{array}{c}\text { Lignin } \\
\text { Guaiacylpropanoid }\end{array}$} & \multicolumn{2}{|c|}{$\begin{array}{c}\text { Lignin } \\
\text { Syringylpropanoid }\end{array}$} & \multicolumn{2}{|c|}{ Cellulose } \\
\hline $\begin{array}{l}\text { Chemical shift } \\
\text { (ppm) }\end{array}$ & Carbon atom & $\begin{array}{l}\text { Chemical shift } \\
\text { (ppm) }\end{array}$ & Carbon atom & $\begin{array}{l}\text { Chemical shift } \\
\text { (ppm) }\end{array}$ & Carbon atom \\
\hline 111 & $\mathrm{C}-2$ & 104 & C-2, C-6 & 65 & C-6 \\
\hline 113 & C-5 & 136 & C-4 & $72-74$ & C-2,C-3,C-5 \\
\hline 121 & C-6 & 138 & C-1 & $83-89$ & $\mathrm{C}-4$ \\
\hline 135 & C-1 & 153 & C-3, C-5 & 105 & $\mathrm{C}-1$ \\
\hline 148 & C-4 & & & & \\
\hline 149 & C-3 & & & & \\
\hline
\end{tabular}




\section{Cellulose}

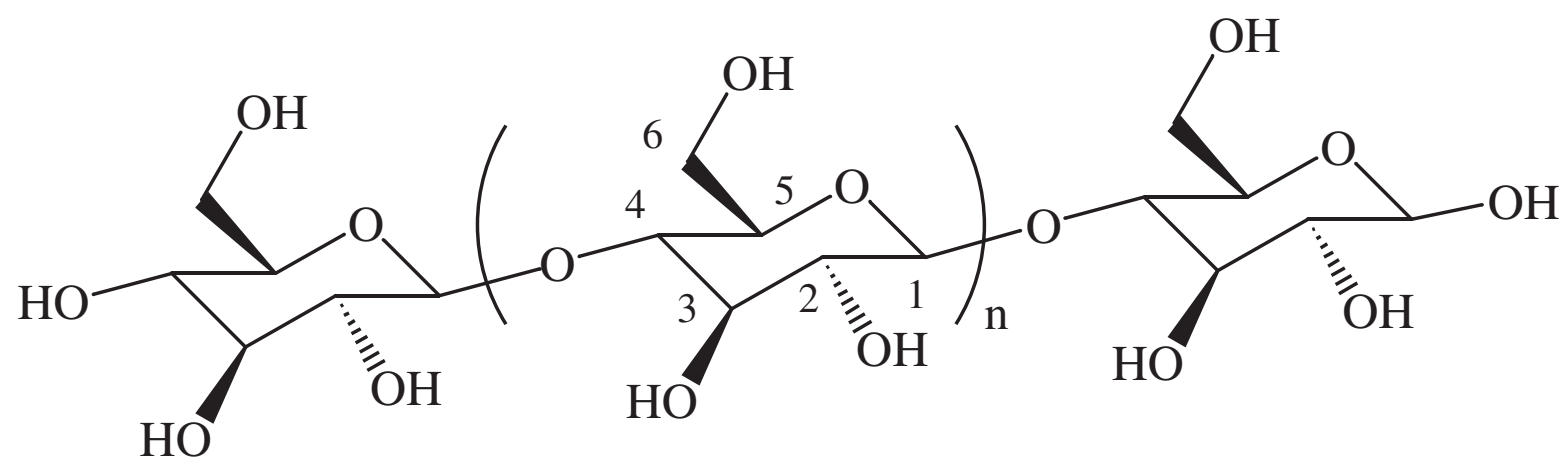

Lignin
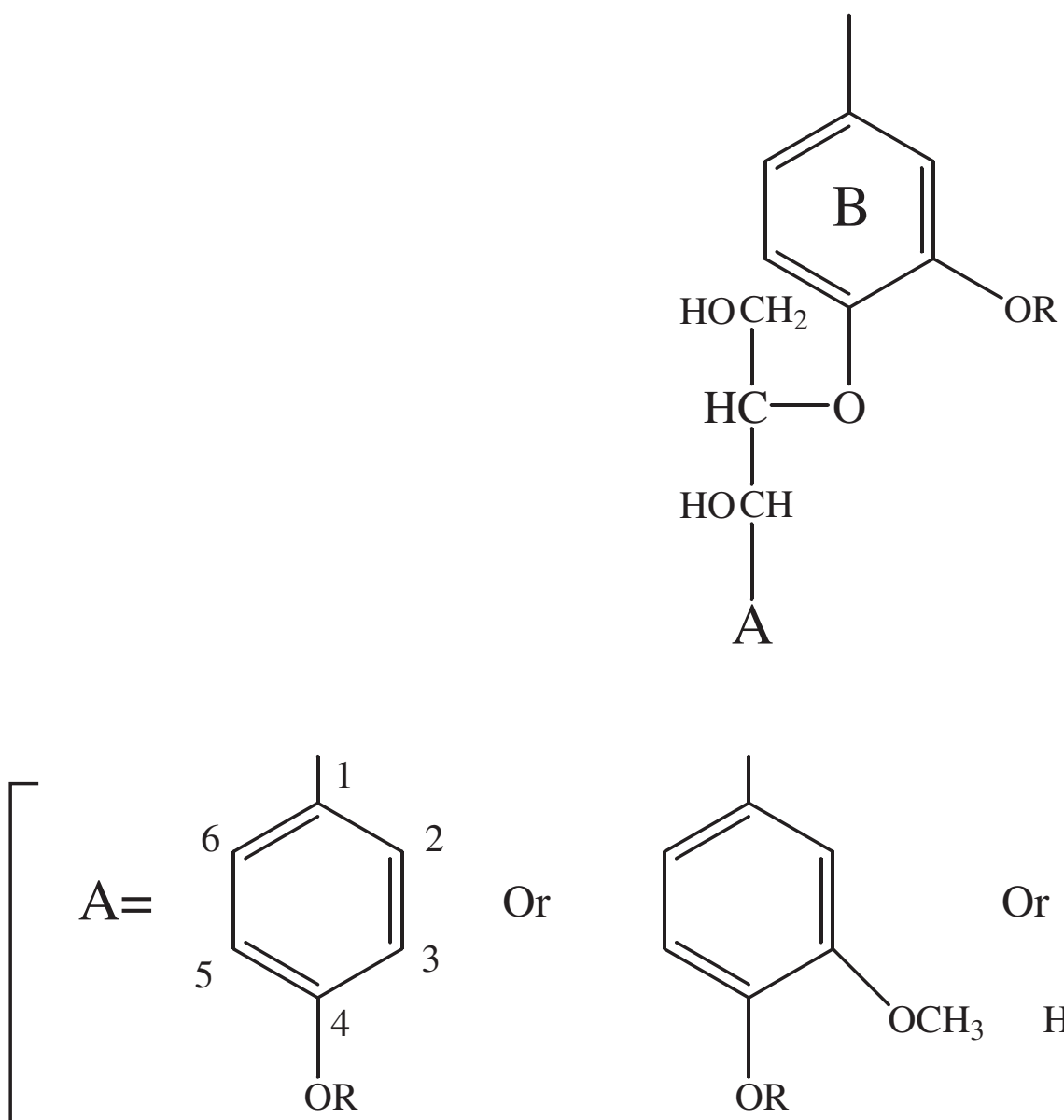<smiles>[R]Oc1ccc(C)cc1OC</smiles>

Guaiacyl<smiles>[R]Oc1c([O])cc(C)cc1OC</smiles>

Syringl

Figure 2. Chemical structures of cellulose and lignin monomeric units. 
Table 3. Percentage aromatic carbon in chars after heating.

$\left[{ }^{\circ} \mathrm{C}\right.$, degrees Celsius; --, no data]

\begin{tabular}{|c|c|c|c|c|c|}
\hline \multirow[b]{2}{*}{ Time (hours) } & \multicolumn{5}{|c|}{ Preparation temperatures } \\
\hline & $250^{\circ} \mathrm{C}$ & $300^{\circ} \mathrm{C}$ & $350^{\circ} \mathrm{C}$ & $400^{\circ} \mathrm{C}$ & $500^{\circ} \mathrm{C}$ \\
\hline \multicolumn{6}{|c|}{ Cellulose (unheated 5.3 percent) } \\
\hline 1 & 1.1 & 71.3 & 78.7 & 81.7 & -- \\
\hline 8 & 61.8 & 83.3 & 88.7 & -- & -- \\
\hline 24 & 77.8 & 90.1 & 85.8 & 87.1 & -- \\
\hline 48 & 80.7 & 92.8 & 80.4 & -- & -- \\
\hline 72 & 83.1 & 82.1 & 81.2 & -- & -- \\
\hline \multicolumn{6}{|c|}{ Lignin (unheated 49.2 percent) } \\
\hline 1 & -- & 61.7 & 71.9 & 80.7 & 88.4 \\
\hline 8 & -- & 66.4 & 85.1 & 91.3 & 91.6 \\
\hline 24 & 57.3 & 77.5 & 87.1 & 87.2 & -- \\
\hline 48 & -- & 81.0 & -- & -- & -- \\
\hline 72 & 63.2 & 79.8 & -- & -- & -- \\
\hline 144 & 65.8 & -- & -- & -- & -- \\
\hline \multicolumn{6}{|c|}{ Poplar wood (unheated 16.8 percent) } \\
\hline 1 & 22.1 & 48.8 & 80.3 & 83.6 & 95.3 \\
\hline 8 & 54.4 & 80.9 & 86.4 & -- & -- \\
\hline 24 & 78.9 & 86.4 & 84.5 & -- & -- \\
\hline 48 & 84.0 & 88.6 & -- & -- & -- \\
\hline 72 & -- & 84.1 & -- & -- & -- \\
\hline 144 & 86.9 & -- & -- & -- & -- \\
\hline \multicolumn{6}{|c|}{ Pine wood (unheated 20.6 percent) } \\
\hline 1 & 25.7 & 56.5 & 85.2 & 91.7 & 100 \\
\hline 8 & 60.1 & 81.7 & 91.3 & -- & -- \\
\hline 24 & 72.0 & 82.7 & 76.7 & -- & -- \\
\hline 48 & 82.3 & 89.6 & -- & -- & -- \\
\hline 72 & -- & 84.6 & -- & -- & -- \\
\hline 168 & 85.1 & -- & -- & -- & -- \\
\hline \multicolumn{6}{|c|}{ Pine bark (unheated 35.1 percent) } \\
\hline 1 & 39.8 & 62.0 & 79.1 & -- & -- \\
\hline 8 & 62.0 & 72.2 & 85.8 & -- & -- \\
\hline 24 & 66.8 & 72.7 & 80.4 & -- & -- \\
\hline 48 & -- & 75.6 & 90.2 & -- & -- \\
\hline 72 & 81.7 & 80.9 & -- & -- & -- \\
\hline 168 & 87.4 & -- & -- & -- & -- \\
\hline
\end{tabular}


The data in table 3 show that the percentage of aromatic carbon increases for all samples with increasing heating temperature at any fixed heating time. Cellulose, pine and poplar woods, and pine bark all show a rapid increase in percentage of aromatic carbon in the first 8 hours of heating at $250^{\circ} \mathrm{C}$ and within the first hour of heating at $300^{\circ} \mathrm{C}$. Lignin starts at a much higher aromatic carbon content in the unaltered state and shows more gradual increases with charring at $250^{\circ} \mathrm{C}$ and $300^{\circ} \mathrm{C}$. Cellulose and both pine and poplar wood reach greater than 80 percent aromatic carbon at $250^{\circ} \mathrm{C}$ between 24 and 48 hours. Pine bark reaches 80 percent aromatic carbon at $250^{\circ} \mathrm{C}$ between 24 and 72 hours. Lignin does not reach 80 percent aromatic carbon at $250^{\circ} \mathrm{C}$ at any heating time up to 144 hours. At $300^{\circ} \mathrm{C}$, cellulose and pine and poplar woods reach 80 percent aromatic carbon between 1 and 8 hours, and lignin reaches 80 percent aromatic carbon between 24 and 48 hours heating. At $350^{\circ} \mathrm{C}$, all samples have reached greater than 80 percent aromatic carbon by 8 hours. At temperatures above $400^{\circ} \mathrm{C}$, all samples tested reached greater than 80 percent aromatic carbon by 1 hour.

\section{Elemental Composition of Char}

Cellulose and lignin samples did not contain substantial ash at any heating time or temperature. Unheated pine and poplar wood contained 0.54 and 0.53 percent ash respectively, with the highest ash content of char reaching approximately 10 percent after heating pine wood for 24 hours at $350^{\circ} \mathrm{C}$ and poplar wood for 48 hours at the same temperature. Unheated pine bark contains 3.23 percent ash, which makes up 32 percent of the char when heated at $350^{\circ} \mathrm{C}$ for 48 hours.

The carbon contents of lignin, cellulose, pine wood, poplar wood, and pine bark and the chars produced from them, are shown in table 4 . The data in table 4 have been normalized to a dry weight and ash-free basis. The percentage carbon in unheated cellulose is calculated to be 44.4 percent. With heating for 1 hour at $250^{\circ} \mathrm{C}$ the percentage carbon did not change. With heating for 1 hour at $300^{\circ} \mathrm{C}, 350^{\circ} \mathrm{C}$, and $400^{\circ} \mathrm{C}$, the percentage carbon in the char increased to about 73,75 , and 79 percent, respectively. With heating at $250^{\circ} \mathrm{C}$ for times greater than 1 hour, the percentage carbon increased to about 65 percent. Longer heating at $300^{\circ} \mathrm{C}, 350^{\circ} \mathrm{C}$, and $400^{\circ} \mathrm{C}$ did not cause any substantial change in percentage carbon.

The percentage carbon in unheated lignin is about 68 percent. With heating for 24 hours at $250^{\circ} \mathrm{C}$ and 1 hour at $300^{\circ} \mathrm{C}$, $350^{\circ} \mathrm{C}, 400^{\circ} \mathrm{C}$, and $500^{\circ} \mathrm{C}$, the percentage carbon in the char increased to about 72, 71, 74, 77, and 85 percent, respectively. Longer heating time did not cause any substantial change in percentage carbon in the char at any temperature.

The percentage carbon in unheated pine and poplar wood is about 51 and 50 percent, respectively. When pine wood is heated for 1 hour at $250^{\circ} \mathrm{C}, 300^{\circ} \mathrm{C}, 350^{\circ} \mathrm{C}, 400^{\circ} \mathrm{C}$, and $500^{\circ} \mathrm{C}$, the percentage carbon in the char increased to about 54,69 , 76,77 , and 84 percent, respectively. With heating at $250^{\circ} \mathrm{C}$ for times greater than 1 hour, the percentage carbon increased to approximately 65 percent. Longer heating at $300^{\circ} \mathrm{C}$ and $350^{\circ} \mathrm{C}$ did not cause any substantial change in percentage carbon. Poplar wood behaves in a similar fashion.

The percentage carbon in unheated pine bark is about 51 percent. With heating for 1 hour at $250^{\circ} \mathrm{C}, 300^{\circ} \mathrm{C}$, and $350^{\circ} \mathrm{C}$, the percentage carbon in the char increased to about 57,66 , and 68 percent, respectively. Longer heating at $250^{\circ} \mathrm{C}$, $300^{\circ} \mathrm{C}$, and $350^{\circ} \mathrm{C}$ did not cause any substantial change in percentage carbon.

Normalized hydrogen percentages for starting materials and their chars are given in table 5 . The percentage hydrogen in unheated cellulose is calculated to be about 6.2 percent. With heating for 1 hour at $250^{\circ} \mathrm{C}$ the percentage hydrogen did not change substantially. With heating for 1 hour at $300^{\circ} \mathrm{C}, 350^{\circ} \mathrm{C}$, and $400^{\circ} \mathrm{C}$, the percentage hydrogen in the char decreased to about 4.0, 3.8, and 3.4 percent, respectively. Heating for times greater than 1 hour caused the percentage hydrogen to decrease for all temperatures.

The percentage hydrogen in unheated lignin is about 5.8 percent. With heating for 24 hours at $250^{\circ} \mathrm{C}$, and 1 hour at $300^{\circ} \mathrm{C}, 350^{\circ} \mathrm{C}, 400^{\circ} \mathrm{C}$, and $500^{\circ} \mathrm{C}$, the percentage hydrogen in the char decreased to about 5.2, 5.2, 4.1, 3.5, and 2.9 percent, respectively. Longer heating caused further decrease in percentage hydrogen in the char for the temperatures studied.

The percentage hydrogen in unheated pine and poplar wood is about 6.3 percent and 6.1 percent, respectively. When pine wood is heated for 1 hour at $250^{\circ} \mathrm{C}, 300^{\circ} \mathrm{C}, 350^{\circ} \mathrm{C}, 400^{\circ} \mathrm{C}$, and $500^{\circ} \mathrm{C}$, the percentage hydrogen in the char decreased to about 5.9, 4.2, 3.2, 2.6, and 2.7 percent, respectively. With heating at $250^{\circ} \mathrm{C}, 300^{\circ} \mathrm{C}$, and $350^{\circ} \mathrm{C}$ for times greater than 24 hours, the percentage hydrogen decreased to between 1.8 and 2.5 percent. Poplar wood behaved in a similar fashion.

The percentage hydrogen in unheated pine bark is about 6.0 percent. With heating for 1 hour at $250^{\circ} \mathrm{C}, 300^{\circ} \mathrm{C}$, and $350^{\circ} \mathrm{C}$, the percentage hydrogen in the char decreased to about 5.3, 4.3, and 3.7 percent, respectively. Longer heating at $250^{\circ} \mathrm{C}, 300^{\circ} \mathrm{C}$, and $350^{\circ} \mathrm{C}$ caused further decrease in percentage hydrogen to between 1.9 to 2.5 percent.

The percentage oxygen shown in table 6 has been estimated by difference, assuming that carbon, hydrogen, oxygen, and ash make up approximately 100 percent of the dry material. The percentage oxygen in unheated cellulose was calculated to be 49.4 percent. With heating for 1 hour at $250^{\circ} \mathrm{C}$ the percentage oxygen did not change substantially. With heating for 1 hour at $300^{\circ} \mathrm{C}, 350^{\circ} \mathrm{C}$, and $400^{\circ} \mathrm{C}$ the percentage oxygen in the char decreased to 23.0, 20.9, and 18.1 percent, respectively. Heating for times greater than 1 hour at $250^{\circ} \mathrm{C}$ did not change the percentage oxygen substantially. Heating for longer than 1 hour at $300^{\circ} \mathrm{C}, 350^{\circ} \mathrm{C}$, and $400^{\circ} \mathrm{C}$ caused the percentage oxygen to increase.

The percentage oxygen in unheated lignin is 26.7 percent. With heating for 24 hours at $250^{\circ} \mathrm{C}$ and 1 hour at $300^{\circ} \mathrm{C}$, $350^{\circ} \mathrm{C}, 400^{\circ} \mathrm{C}$ and $500^{\circ} \mathrm{C}$, the percentage oxygen in the char decreased to 23.2, 23.6, 21.6, 19.8 and 12.6 percent, respectively. Longer heating causes a slight increase in percentage oxygen in the char for the temperatures studied. 
The percentage oxygen in unheated pine and poplar wood is 42.5 percent and 44.0 percent, respectively. When pine wood is heated for 1 hour at $250^{\circ} \mathrm{C}, 300^{\circ} \mathrm{C}, 350^{\circ} \mathrm{C}, 400^{\circ} \mathrm{C}$ and $500^{\circ} \mathrm{C}$, the percentage oxygen in the char decreased to $40.4,26.6,20.5,20.0$, and 13.3 percentage respectively. With heating at $250^{\circ} \mathrm{C}$ for times greater than 1 hour, the percentage oxygen decreased slightly. With heating at $300^{\circ} \mathrm{C}$ and $350^{\circ} \mathrm{C}$

for times greater than 1 hour, the percentage oxygen increased slightly. Poplar wood behaves in a similar fashion.

The percentage oxygen in unheated pine bark is 42.7 percent. With heating for 1 hour at $250^{\circ} \mathrm{C}, 300^{\circ} \mathrm{C}$, and $350^{\circ} \mathrm{C}$, the percentage oxygen in the char decreased to $37.3,30.1$, and 28.0 percent, respectively. Longer heating at $300^{\circ} \mathrm{C}$, and $350^{\circ} \mathrm{C}$ caused an increase in percentage oxygen. 
Table 4. Percentage carbon remaining in char after heating, normalized to a dry and ash-free basis.

$\left[{ }^{\circ} \mathrm{C}\right.$, degrees Celsius; --, no data]

\begin{tabular}{|c|c|c|c|c|c|}
\hline \multirow[b]{2}{*}{ Time (hours) } & \multicolumn{5}{|c|}{ Preparation Temperature } \\
\hline & $250^{\circ} \mathrm{C}$ & $300^{\circ} \mathrm{C}$ & $350^{\circ} \mathrm{C}$ & $400^{\circ} \mathrm{C}$ & $500^{\circ} \mathrm{C}$ \\
\hline \multicolumn{6}{|c|}{ Cellulose (unheated 44.4 percent) } \\
\hline 1 & 44.1 & 73.0 & 75.4 & 78.5 & -- \\
\hline 8 & 65.1 & 71.0 & 74.3 & -- & -- \\
\hline 24 & 63.7 & 69.3 & 69.2 & 72.0 & -- \\
\hline 48 & 64.5 & 65.4 & 66.2 & -- & -- \\
\hline 72 & 63.3 & 64.4 & 65.3 & -- & -- \\
\hline \multicolumn{6}{|c|}{ Lignin (unheated 67.6 percent) } \\
\hline 1 & -- & 71.2 & 74.3 & 76.7 & 84.6 \\
\hline 8 & -- & 72.2 & 73.5 & 73.9 & 82.2 \\
\hline 24 & 71.6 & 73.8 & 69.3 & 73.2 & -- \\
\hline 48 & -- & 71.2 & 67.6 & -- & -- \\
\hline 72 & 70.3 & 69.9 & 66.3 & -- & -- \\
\hline 144 & 70.0 & -- & -- & -- & -- \\
\hline \multicolumn{6}{|c|}{ Poplar wood (unheated 49.9 percent) } \\
\hline 1 & 53.4 & 67.6 & 76.2 & 79.1 & 86.6 \\
\hline 8 & 61.4 & 72.7 & 75.6 & -- & -- \\
\hline 24 & 65.4 & 67.1 & 68.7 & -- & -- \\
\hline 48 & -- & 65.4 & 65.3 & -- & -- \\
\hline 72 & 65.5 & 66.0 & -- & -- & -- \\
\hline 144 & 64.2 & -- & -- & -- & -- \\
\hline \multicolumn{6}{|c|}{ Pine wood (unheated 51.2 percent) } \\
\hline 1 & 53.7 & 69.1 & 76.2 & 77.4 & 84.0 \\
\hline 8 & 63.0 & 71.2 & 69.8 & -- & -- \\
\hline 24 & 65.4 & 67.1 & 68.9 & -- & -- \\
\hline 48 & 65.5 & 67.3 & -- & -- & -- \\
\hline 72 & -- & 65.9 & -- & -- & -- \\
\hline 168 & 62.8 & -- & -- & -- & -- \\
\hline \multicolumn{6}{|c|}{ Pine bark (unheated 51.3 percent) } \\
\hline 1 & 57.4 & 65.6 & 68.3 & -- & -- \\
\hline 8 & 62.4 & 64.6 & 68.5 & -- & -- \\
\hline 24 & 62.6 & 63.0 & 65.0 & -- & -- \\
\hline 48 & -- & 60.2 & 52.0 & -- & -- \\
\hline 72 & 60.1 & 57.2 & -- & -- & -- \\
\hline 168 & 59.2 & -- & -- & -- & -- \\
\hline
\end{tabular}


Table 5. Percentage hydrogen remaining in char after heating, normalized to a dry and ash-free basis.

$\left[{ }^{\circ} \mathrm{C}\right.$, degrees Celsius; --, no data]

\begin{tabular}{|c|c|c|c|c|c|}
\hline \multirow[b]{2}{*}{ Time (hours) } & \multicolumn{5}{|c|}{ Preparation temperature } \\
\hline & $250^{\circ} \mathrm{C}$ & $300^{\circ} \mathrm{C}$ & $350^{\circ} \mathrm{C}$ & $400^{\circ} \mathrm{C}$ & $500^{\circ} \mathrm{C}$ \\
\hline \multicolumn{6}{|c|}{ Cellulose (unheated 6.17 percent) } \\
\hline 1 & 6.30 & 3.97 & 3.75 & 3.39 & -- \\
\hline 8 & 3.66 & 3.02 & 2.54 & -- & -- \\
\hline 24 & 2.39 & 1.44 & 1.93 & 1.58 & -- \\
\hline 48 & 2.45 & 1.87 & 1.77 & -- & -- \\
\hline 72 & 2.19 & 1.90 & 1.78 & -- & -- \\
\hline \multicolumn{6}{|c|}{ Lignin (unheated 5.78 percent) } \\
\hline 1 & -- & 5.24 & 4.09 & 3.46 & 2.94 \\
\hline 8 & -- & 4.68 & 2.99 & 2.32 & 2.25 \\
\hline 24 & 5.23 & 3.97 & 1.77 & 1.02 & -- \\
\hline 48 & -- & 3.67 & 1.65 & -- & -- \\
\hline 72 & 4.95 & 2.68 & 1.60 & -- & -- \\
\hline 144 & 4.88 & -- & -- & -- & -- \\
\hline \multicolumn{6}{|c|}{ Poplar wood (unheated 6.06 percent) } \\
\hline 1 & 5.66 & 4.65 & 3.30 & 2.82 & 2.62 \\
\hline 8 & 4.11 & 2.98 & 2.66 & -- & -- \\
\hline 24 & 2.60 & 1.94 & 2.13 & -- & -- \\
\hline 48 & -- & 2.15 & 2.01 & -- & -- \\
\hline 72 & 1.86 & 1.79 & -- & -- & -- \\
\hline 144 & 1.81 & -- & -- & -- & -- \\
\hline \multicolumn{6}{|c|}{ Pine wood (unheated 6.31 percent) } \\
\hline 1 & 5.88 & 4.25 & 3.23 & 2.58 & 2.72 \\
\hline 8 & 4.49 & 3.03 & 2.17 & -- & -- \\
\hline 24 & 2.92 & 2.30 & 2.51 & -- & -- \\
\hline 48 & 2.43 & 1.80 & -- & -- & -- \\
\hline 72 & -- & 2.10 & -- & -- & -- \\
\hline 168 & 2.15 & -- & -- & -- & -- \\
\hline \multicolumn{6}{|c|}{ Pine bark (unheated 5.97 percent) } \\
\hline 1 & 5.28 & 4.32 & 3.74 & -- & -- \\
\hline 8 & 3.92 & 3.29 & 3.27 & -- & -- \\
\hline 24 & 3.18 & 2.85 & 2.86 & -- & -- \\
\hline 48 & -- & 2.38 & 1.94 & -- & -- \\
\hline 72 & 2.43 & 2.51 & & -- & -- \\
\hline 168 & 2.34 & -- & -- & -- & -- \\
\hline
\end{tabular}


Table 6. Percentage oxygen remaining in char after heating, determined by difference from ash, carbon and hydrogen content.

$\left[{ }^{\circ} \mathrm{C}\right.$, degrees Celsius; --, no data]

\begin{tabular}{|c|c|c|c|c|c|}
\hline \multirow[b]{2}{*}{ Time (hours) } & \multicolumn{5}{|c|}{ Preparation temperature } \\
\hline & $250^{\circ} \mathrm{C}$ & $300^{\circ} \mathrm{C}$ & $350^{\circ} \mathrm{C}$ & $400^{\circ} \mathrm{C}$ & $500^{\circ} \mathrm{C}$ \\
\hline \multicolumn{6}{|c|}{ Cellulose (unheated 49.4 percent) } \\
\hline 1 & 49.6 & 23.0 & 20.9 & 18.1 & -- \\
\hline 8 & 31.2 & 26.0 & 23.1 & -- & -- \\
\hline 24 & 33.9 & 29.3 & 28.9 & 26.4 & -- \\
\hline 48 & 33.0 & 32.8 & 32.0 & -- & -- \\
\hline 72 & 34.5 & 33.7 & 32.9 & -- & -- \\
\hline \multicolumn{6}{|c|}{ Lignin (unheated 26.7 percent) } \\
\hline 1 & -- & 23.6 & 21.6 & 19.8 & 12.5 \\
\hline 8 & -- & 23.1 & 23.5 & 23.8 & 15.6 \\
\hline 24 & 23.2 & 22.2 & 28.9 & 25.8 & -- \\
\hline 48 & -- & 25.1 & 30.8 & -- & -- \\
\hline 72 & 24.7 & 27.5 & 32.1 & -- & -- \\
\hline 144 & 25.2 & -- & -- & -- & -- \\
\hline \multicolumn{6}{|c|}{ Poplar wood (unheated 44.0 percent) } \\
\hline 1 & 40.9 & 27.8 & 20.5 & 18.0 & 10.8 \\
\hline 8 & 34.5 & 24.3 & 21.7 & -- & -- \\
\hline 24 & 32.0 & 30.9 & 29.2 & -- & -- \\
\hline 48 & -- & 32.5 & 32.6 & -- & -- \\
\hline 72 & 32.7 & 32.3 & -- & -- & -- \\
\hline 144 & 34.0 & -- & -- & -- & -- \\
\hline \multicolumn{6}{|c|}{ Pine wood (unheated 42.5 percent) } \\
\hline 1 & 40.4 & 26.6 & 20.5 & 20.0 & 13.3 \\
\hline 8 & 32.5 & 25.7 & 28.0 & -- & -- \\
\hline 24 & 31.7 & 30.6 & 28.5 & -- & -- \\
\hline 48 & 32.0 & 30.9 & -- & -- & -- \\
\hline 72 & -- & 32.0 & -- & -- & -- \\
\hline 168 & 35.0 & -- & -- & -- & -- \\
\hline \multicolumn{6}{|c|}{ Pine bark (unheated 42.7 percent) } \\
\hline 1 & 37.3 & 30.1 & 28.0 & -- & -- \\
\hline 8 & 33.7 & 32.1 & 28.2 & -- & -- \\
\hline 24 & 34.2 & 34.1 & 32.1 & -- & -- \\
\hline 48 & -- & 37.4 & 46.0 & -- & -- \\
\hline 72 & 37.5 & 40.3 & -- & -- & -- \\
\hline 168 & 38.5 & -- & -- & -- & -- \\
\hline
\end{tabular}




\section{Hydrogen/Carbon Ratios and Oxygen/Carbon Ratios of Chars}

The hydrogen/carbon $(\mathrm{H} / \mathrm{C})$ atomic ratios and oxygen/ carbon $(\mathrm{O} / \mathrm{C})$ atomic ratios of the chars, listed in table 7 , show the evolution of the char with time and temperature treatments on a molar basis. The increase in concentration of fused-ring aromatic structures with heating time and temperature for the charcoal samples from cellulose, lignin, and the charred wood and bark samples that was demonstrated by the NMR analyses also was supported by the elemental composition data. The $\mathrm{H} / \mathrm{C}$ atomic ratios decrease with duration of heating and heating temperature (table 7). Ratios less than one are indicative of fused-ring aromatic structures in which only the peripheral carbon atoms are protonated (Yang and others, 2002). Song and others (2002) isolated BC from soils and sediments from suburban Guangzhou City, China, by using a wet chemical oxidation procedure. The $\mathrm{H} / \mathrm{C}$ ratios of their $\mathrm{BC}$ samples from soils and sediments varied from 0.5 to 0.71 . In addition, they measured a $\mathrm{H} / \mathrm{C}$ ratio of 0.37 for char they produced by heating "arbor wood" in a kiln.

The chars produced in this study, regardless of starting material, evolved with time into a fairly uniform elemental composition. Cellulose and both pine and poplar woods developed $\mathrm{H} / \mathrm{C}$ ratios of 0.3 to 0.4 and $\mathrm{O} / \mathrm{C}$ ratios of 0.1 to 0.4 for temperatures from $250^{\circ} \mathrm{C}$ to $500^{\circ} \mathrm{C}$. Lignin did not substantially alter at $250^{\circ} \mathrm{C}$. For temperatures from $300^{\circ} \mathrm{C}$ to $500^{\circ} \mathrm{C}$, lignin developed $\mathrm{H} / \mathrm{C}$ ratios of 0.3 to 0.5 and $\mathrm{O} / \mathrm{C}$ ratios of 0.1 to 0.4 . For temperatures from $300^{\circ} \mathrm{C}$ to $350^{\circ} \mathrm{C}$, pine bark developed a $\mathrm{H} / \mathrm{C}$ ratio of 0.5 , and $\mathrm{O} / \mathrm{C}$ ratios of 0.5 to 0.7 .

\section{Aromatic and Aliphatic Carbon Content of Chars}

The NMR spectra showed an increase in percentage aromatic carbon that can be caused either by the formation of aromatic carbon in the charring process or by the preferential removal of aliphatic components during the charring process. Further insight into this process can be gained by transforming the percentage carbon data into grams of aromatic carbon or aliphatic carbon per 100 grams of starting material. This was done by multiplying the percentage carbon from table 4 by the fraction of aromatic carbon or aliphatic carbon in the char (from table 3 ) and by the fraction of char remaining (from table 1). These data are presented in table 8 and in figures 3-7.

At $250^{\circ} \mathrm{C}$, the total mass of aromatic carbon in cellulose and both wood samples and the pine bark increased during the first 8 to 24 hours of heating and decreased only slightly with longer heating durations. Lignin showed a slight increase in aromatic carbon throughout the heating periods studied. This shows that at this temperature there is formation of aromatic carbon from aliphatic carbon and little or no decomposition of the aromatic components. At $300^{\circ} \mathrm{C}$, the total mass of aromatic carbon in cellulose and both wood samples increased with heating for 8 hours and then decreased more rapidly with further heating than observed at $250^{\circ} \mathrm{C}$. Pine bark increased in aromatic carbon only for the first hour and then decreased. Aromatic carbon in lignin continued to increase for 24 hours and then decreased. At $350^{\circ} \mathrm{C}$ and above, all samples showed a more rapid decrease in aromatic carbon after the first hour of heating.

Aliphatic carbon content decreased with increased heating temperature with the rate of loss increasing with increasing heating temperature.

\section{$\mathrm{H} / \mathrm{C}$ and $\mathrm{O} / \mathrm{C}$ Atomic Ratios of Material Lost from Char}

The change in the percentage of carbon, hydrogen, and oxygen in the char indicated that these elements were leaving the char at different rates. When the elemental composition in tables 4-6 are multiplied by the fraction of char remaining (table 1), an estimate is made of the elemental composition normalized to $100 \mathrm{~g}$ of starting material. From this, an estimate of elemental loss can be made for each time interval of heating. Table 9 shows the $\mathrm{H} / \mathrm{C}$ and $\mathrm{O} / \mathrm{C}$ atomic ratios of material lost during heating. Ratios greater than 1 show when hydrogen and oxygen are being lost at a greater rate than carbon.

For heating of cellulose, wood, and bark at $250^{\circ} \mathrm{C}$, the loss of hydrogen exceeds carbon loss for the first 24 hours by as much as 8 to 1 . After 24 hours, the loss of hydrogen equals or is less than the loss of carbon. For lignin the loss of hydrogen exceeds the loss of carbon for all intervals of heating at $250^{\circ} \mathrm{C}$. The duration during which hydrogen loss exceeds carbon loss becomes shorter at higher temperatures. With increased heating time, at any temperature the ratio decreases and more closely equals that of the char material.

Oxygen loss for all materials and temperatures, except for lignin at $250^{\circ} \mathrm{C}$, is at a maximum within the first 8 hours and then decreases to a ratio that resembles the ratio in the char.

The $\mathrm{H} / \mathrm{C}$ and $\mathrm{O} / \mathrm{C}$ ratios of material lost are consistent with the data presented on the composition of the char, which indicate that aliphatic matter is lost early in the charring process and at increasing rates with increasing temperature, and that the aliphatic components are lost before the aromatic components start to degrade. 
Table 7. Hydrogen/carbon atomic ratios and oxygen/carbon atomic ratios of chars.

$\left[{ }^{\circ} \mathrm{C}\right.$, degrees Celsius; --, no data. The oxygen/carbon ratios are in brackets.]

\begin{tabular}{|c|c|c|c|c|c|}
\hline \multirow[b]{2}{*}{ Time (hours) } & \multicolumn{5}{|c|}{ Preparation temperature } \\
\hline & $250^{\circ} \mathrm{C}$ & $300^{\circ} \mathrm{C}$ & $350^{\circ} \mathrm{C}$ & $400^{\circ} \mathrm{C}$ & $500^{\circ} \mathrm{C}$ \\
\hline \multicolumn{6}{|c|}{ Cellulose (unheated $1.7[0.8]$ ) } \\
\hline 1 & $1.7[0.8]$ & $0.7[0.2]$ & $0.6[0.2]$ & $0.5[0.2]$ & -- \\
\hline 8 & $0.7[0.4]$ & $0.5[0.3]$ & $0.4[0.2]$ & -- & -- \\
\hline 24 & $0.5[0.4]$ & $0.3[0.3]$ & $0.3[0.3]$ & $0.3[0.3]$ & -- \\
\hline 48 & $0.7[0.4]$ & $0.3[0.4]$ & $0.3[0.4]$ & -- & -- \\
\hline 72 & $0.4[0.4]$ & $0.4[0.4]$ & $0.3[0.4]$ & -- & -- \\
\hline \multicolumn{6}{|c|}{ Lignin (unheated $1.0[0.3]$ ) } \\
\hline 1 & -- & $0.9[0.3]$ & $0.7[0.2]$ & $0.5[0.2]$ & $0.4[0.1]$ \\
\hline 8 & -- & $0.8[0.2]$ & $0.5[0.2]$ & $0.4[0.2]$ & $0.3[0.1]$ \\
\hline 24 & $0.9[0.2]$ & $0.6[0.2]$ & $0.3[0.3]$ & $0.2[0.3]$ & -- \\
\hline 48 & -- & $0.6[0.3]$ & $0.3[0.3]$ & -- & -- \\
\hline 72 & $0.9[0.3]$ & $0.5[0.3]$ & $0.3[0.4]$ & -- & -- \\
\hline 144 & $0.9[0.3]$ & -- & -- & -- & -- \\
\hline \multicolumn{6}{|c|}{ Poplar wood (unheated $1.5[0.7])$} \\
\hline 1 & $1.2[0.6]$ & $0.8[0.3]$ & $0.5[0.2]$ & $0.4[0.2]$ & $0.4[0.1]$ \\
\hline 8 & $0.8[0.4]$ & $0.5[0.3]$ & $0.4[0.2]$ & -- & -- \\
\hline 24 & $0.5[0.4]$ & $0.4[0.4]$ & $0.4[0.3]$ & -- & -- \\
\hline 48 & -- & $0.4[0.4]$ & $0.4[0.4]$ & -- & -- \\
\hline 72 & $0.3[0.4]$ & $0.3[0.7]$ & -- & -- & -- \\
\hline 144 & $0.3[0.4]$ & -- & -- & -- & -- \\
\hline \multicolumn{6}{|c|}{ Pine wood (unheated $1.5[0.6]$ ) } \\
\hline 1 & $1.3[0.6]$ & $0.7[0.3]$ & $0.5[0.2]$ & $0.4[0.2]$ & $0.4[0.1]$ \\
\hline 8 & $0.9[0.4]$ & $0.5[0.3]$ & $0.4[0.3]$ & -- & -- \\
\hline 24 & $0.5[0.4]$ & $0.4[0.3]$ & $0.4[0.3]$ & -- & -- \\
\hline 48 & $0.4[0.4]$ & $0.3[0.3]$ & -- & -- & -- \\
\hline 72 & -- & $0.4[0.4]$ & -- & -- & -- \\
\hline 168 & $0.4[0.4]$ & -- & -- & -- & -- \\
\hline \multicolumn{6}{|c|}{ Pine bark (unheated 1.4 [0.6]) } \\
\hline 1 & $1.1[0.5]$ & $0.8[0.3]$ & $0.7[0.3]$ & -- & -- \\
\hline 8 & $0.8[0.4]$ & $0.6[0.4]$ & $0.6[0.3]$ & -- & -- \\
\hline 24 & $0.6[0.4]$ & $0.5[0.4]$ & $0.5[0.4]$ & -- & -- \\
\hline 48 & -- & $0.5[0.5]$ & $0.5[0.7]$ & -- & -- \\
\hline 72 & $0.5[0.5]$ & $0.5[0.5]$ & -- & -- & -- \\
\hline 168 & $0.5[0.5]$ & -- & -- & -- & -- \\
\hline
\end{tabular}


Table 8. Grams of aromatic carbon or aliphatic carbon in char per 100 grams of starting material.

$\left[{ }^{\circ} \mathrm{C}\right.$, degrees Celsius; --, no data. The grams of aliphatic carbon are in brackets.]

\begin{tabular}{|c|c|c|c|c|c|}
\hline \multirow[b]{2}{*}{ Time (hours) } & \multicolumn{5}{|c|}{ Preparation temperature } \\
\hline & $250^{\circ} \mathrm{C}$ & $300^{\circ} \mathrm{C}$ & $350^{\circ} \mathrm{C}$ & $400^{\circ} \mathrm{C}$ & $500^{\circ} \mathrm{C}$ \\
\hline \multicolumn{6}{|c|}{ Cellulose (unheated 0.0 [44.4]) } \\
\hline 1 & $0.45[40.8]$ & $17.3[6.98]$ & $16.5[4.46]$ & $14.3[3.20]$ & -- \\
\hline 8 & $17.8[11.0]$ & $18.2[3.63]$ & 15.5 [1.98] & -- & -- \\
\hline 24 & $17.5[5.00]$ & $17.0[1.86]$ & $11.2[1.86]$ & $4.89[1.73]$ & -- \\
\hline 48 & 18.1 [4.33] & $14.5[1.12]$ & $6.82[1.66]$ & -- & -- \\
\hline 72 & $16.5[3.37]$ & $11.7[2.56]$ & $4.78[1.11]$ & -- & -- \\
\hline \multicolumn{6}{|c|}{ Lignin (unheated 33.3 [34.3]) } \\
\hline 1 & -- & 33.7 [20.9] & 34.4 [13.4] & 32.1 [7.67] & $29.1[3.81]$ \\
\hline 8 & -- & $33.6[17.0]$ & $34.6[6.06]$ & $25.8[2.46]$ & $14.4[1.32]$ \\
\hline 24 & $34.7[25.9]$ & $38.8[11.2]$ & $24.9[3.67]$ & $9.95[1.46]$ & -- \\
\hline 48 & -- & $36.7[8.61]$ & $18.4[3.81]$ & -- & -- \\
\hline 72 & $35.8[20.9]$ & $33.0[8.38]$ & $13.7[2.12]$ & -- & -- \\
\hline 144 & $36.8[19.2]$ & -- & -- & -- & -- \\
\hline \multicolumn{6}{|c|}{ Poplar wood (unheated 8.35 [41.3]) } \\
\hline 1 & $8.92[31.4]$ & $13.6[14.3]$ & $16.4[4.02]$ & $14.9[2.93]$ & $13.0[0.64]$ \\
\hline 8 & $14.1[11.8]$ & $16.2[3.81]$ & $13.1[2.06]$ & -- & -- \\
\hline 24 & $19.6[5.22]$ & $12.5[1.95]$ & $6.39[1.17]$ & -- & -- \\
\hline 48 & -- & $10.5[1.35]$ & -- & -- & -- \\
\hline 72 & $18.0[3.43]$ & $8.54[1.61]$ & -- & -- & -- \\
\hline 144 & $16.4[2.47]$ & -- & -- & -- & -- \\
\hline \multicolumn{6}{|c|}{ Pine wood (unheated 10.5 [40.4]) } \\
\hline 1 & $10.9[31.5]$ & $16.4[12.7]$ & $17.2[2.99]$ & $15.8[1.43]$ & $11.5[0.0]$ \\
\hline 8 & $21.0[13.9]$ & $19.0[4.25]$ & $13.2[1.26]$ & -- & -- \\
\hline 24 & $20.2[7.88]$ & $13.7[2.88]$ & $2.43[0.74]$ & -- & -- \\
\hline 48 & $19.3[4.17]$ & $11.8[1.37]$ & -- & -- & -- \\
\hline 72 & -- & $9.41[1.71]$ & -- & -- & -- \\
\hline 168 & $16.0[2.8]$ & -- & -- & -- & -- \\
\hline \multicolumn{6}{|c|}{ Pine bark (unheated 17.5 [32.2]) } \\
\hline 1 & $16.1[24.3]$ & $20.7[12.7]$ & $22.5[5.93]$ & -- & -- \\
\hline 8 & $22.1[13.6]$ & $20.8[8.01]$ & $17.8[2.93]$ & -- & -- \\
\hline 24 & $20.5[10.2]$ & $14.2[5.34]$ & $8.71[2.13]$ & -- & -- \\
\hline 48 & -- & 9.97 [3.23] & $2.90[0.32]$ & -- & -- \\
\hline 72 & 19.4 [4.35] & $7.05[1.67]$ & -- & -- & -- \\
\hline 168 & $16.2[2.35]$ & -- & -- & -- & -- \\
\hline
\end{tabular}




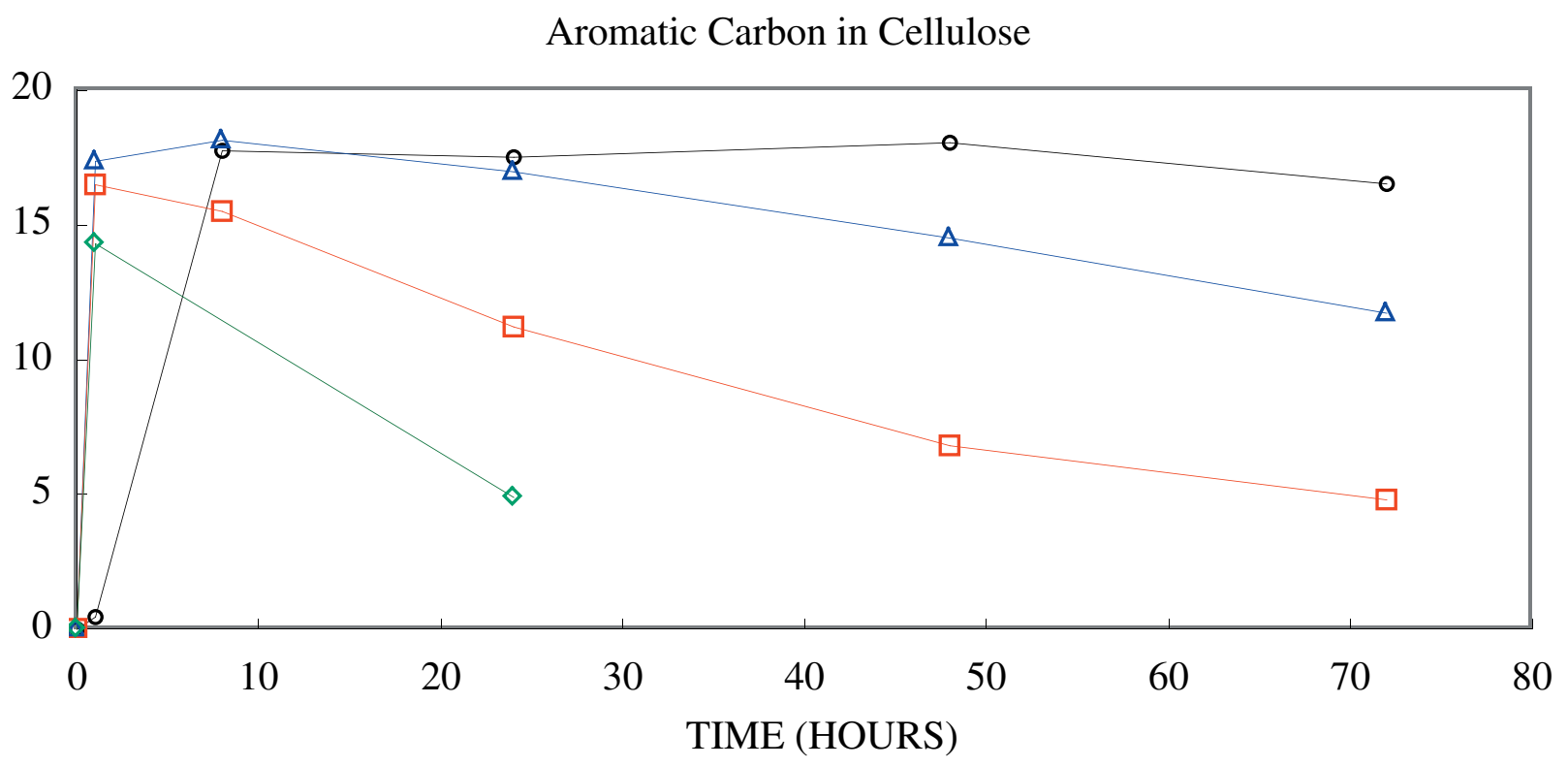

Aliphatic Carbon in Cellulose

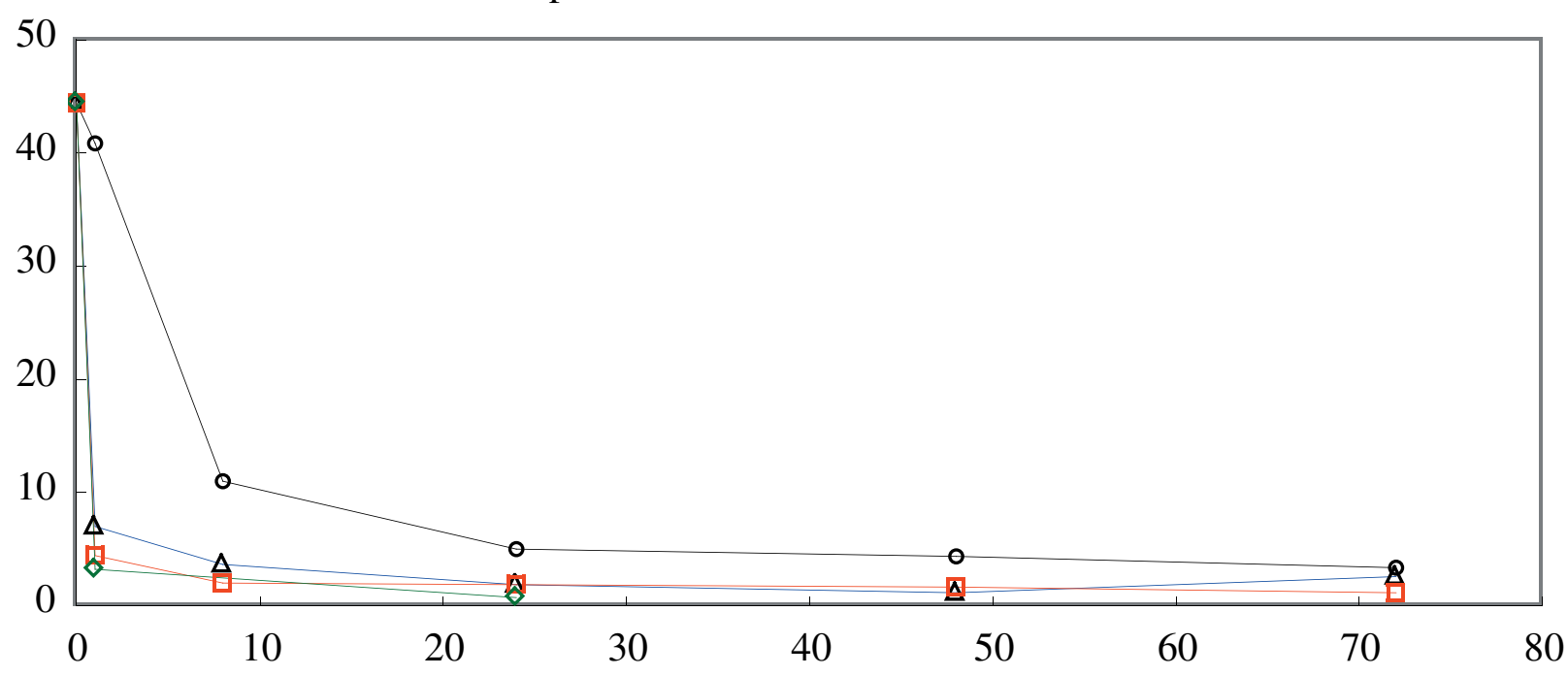

TIME (HOURS)

\section{EXPLANATION}

$\begin{array}{ll}\rightarrow 250 \text { Degrees Celsius } & \Delta 300 \text { Degrees Celsius } \\ \square-350 \text { Degrees Celsius } & \diamond-400 \text { Degrees Celsius }\end{array}$

Figure 3. Calculated aromatic and aliphatic carbon content (grams carbon/100 grams starting material) in cellulose and cellulose char at various heating times and temperatures. 

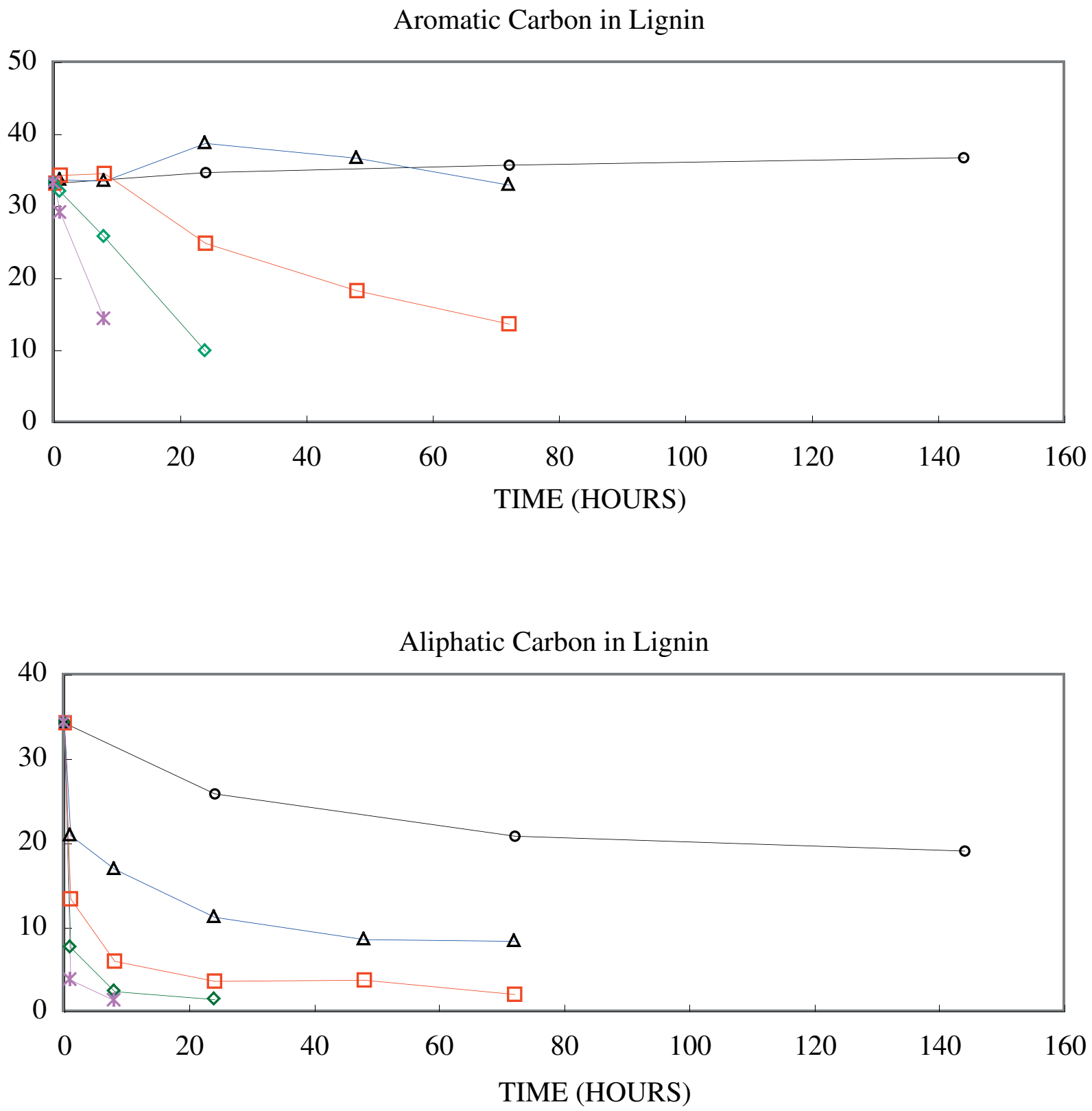

EXPLANATION

$\triangle 250$ Degrees Celsius $\triangle-300$ Degrees Celsius $\square-350$ Degrees Celsius

$\diamond 400$ Degrees Celsius $* 500$ Degrees Celsius

Figure 4. Calculated aromatic and aliphatic carbon content (grams carbon/100 grams starting material) in lignin and lignin char at various heating times and temperatures. 
Aromatic Carbon in Poplar Wood
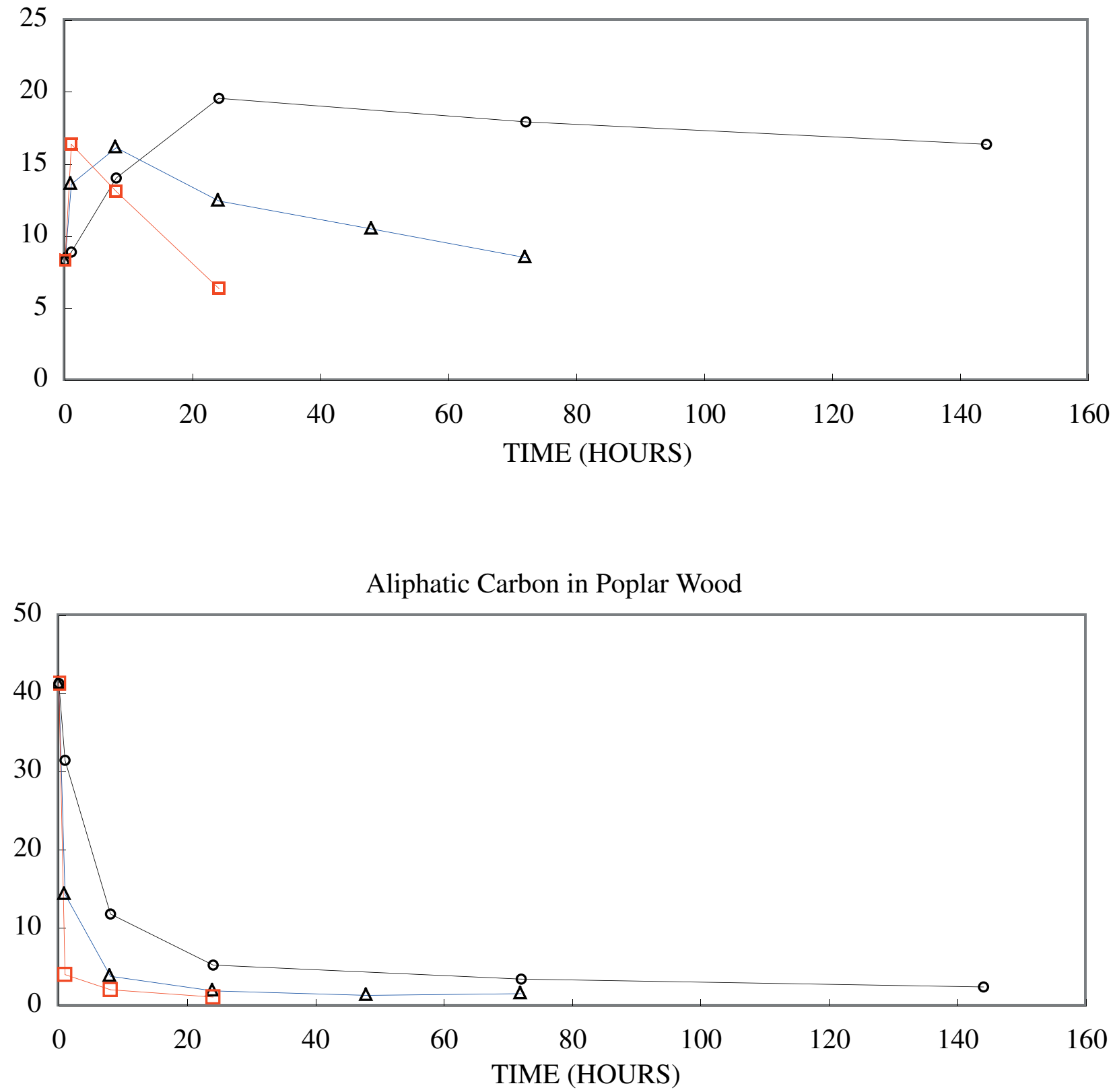

\section{EXPLANATION}

$\rightarrow 250$ Degrees Celsius $\quad \Delta-300$ Degrees Celsius $\quad \square-350$ Degrees Celsius

Figure 5. Calculated aromatic and aliphatic carbon content (grams carbon/100 grams starting material) in poplar wood and chars at various heating times and temperatures. 
Aromatic Carbon in Pine Wood
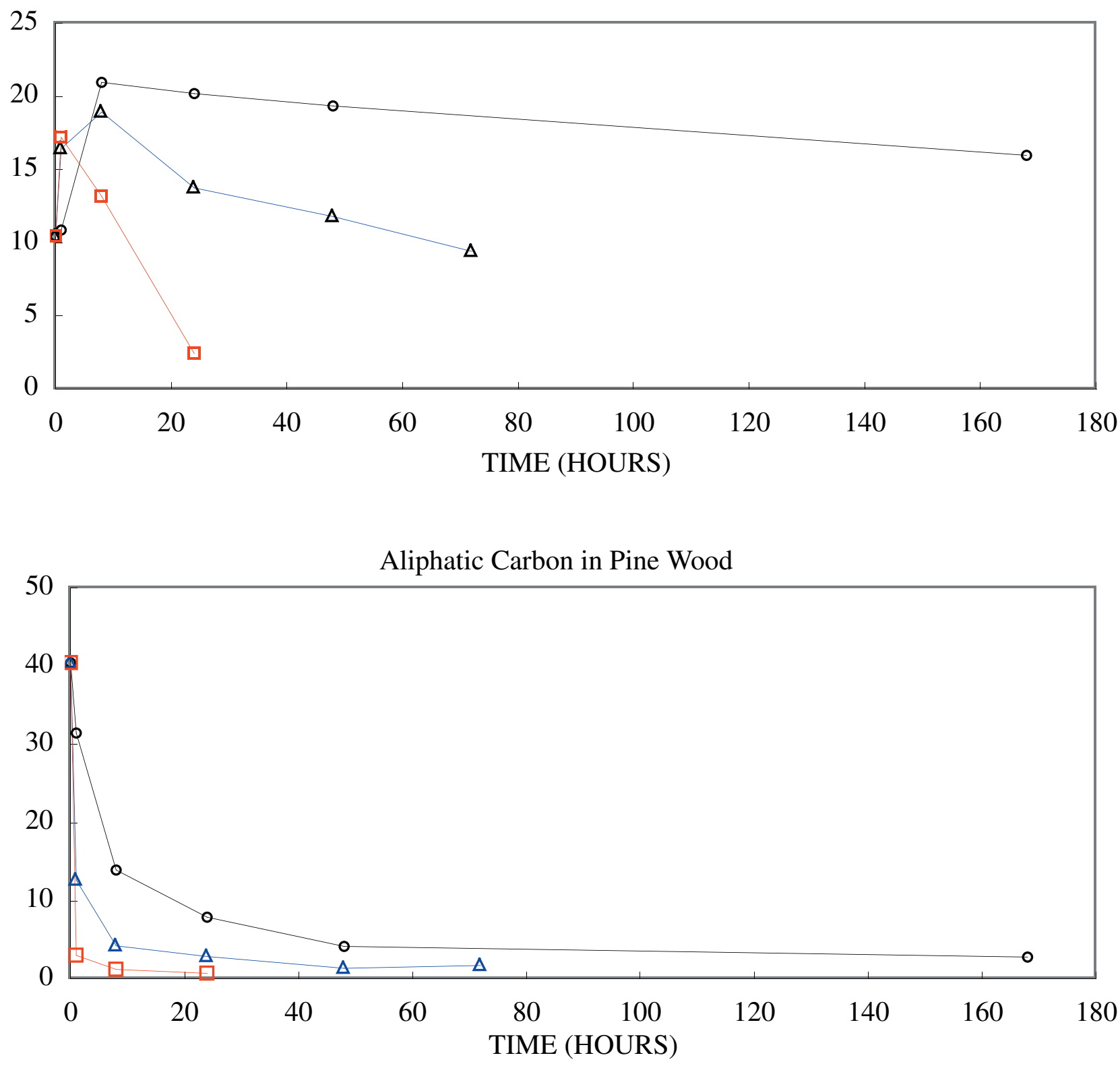

\section{EXPLANATION $\because 250$ Degrees Celsius $\quad \triangle 300$ Degrees Celsius $\quad \square-350$ Degrees Celsius}

Figure 6. Calculated aromatic and aliphatic carbon content (grams carbon/100 grams starting material) in pine wood and chars at various heating times and temperatures. 
Aromatic Carbon in Pine Bark

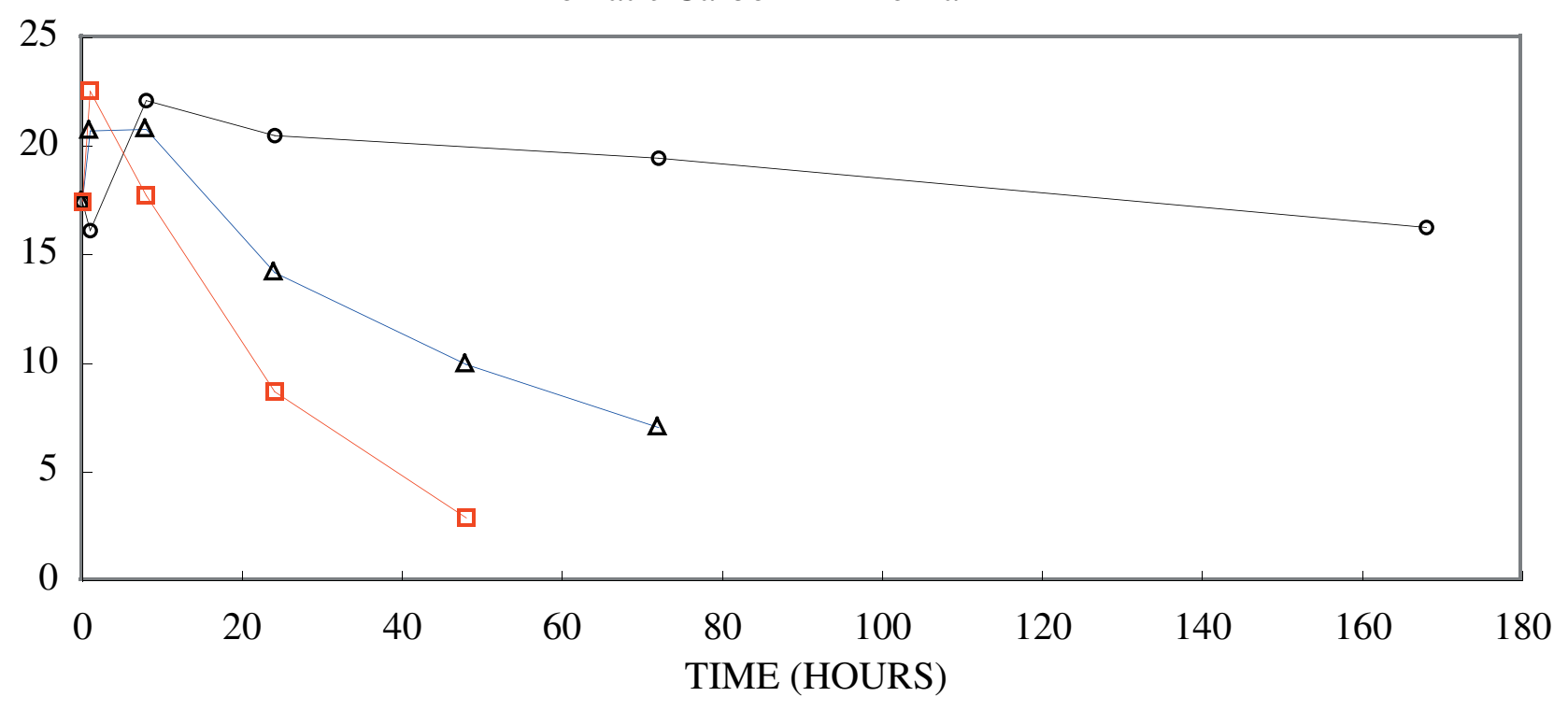

Aliphatic Carbon in Pine Bark

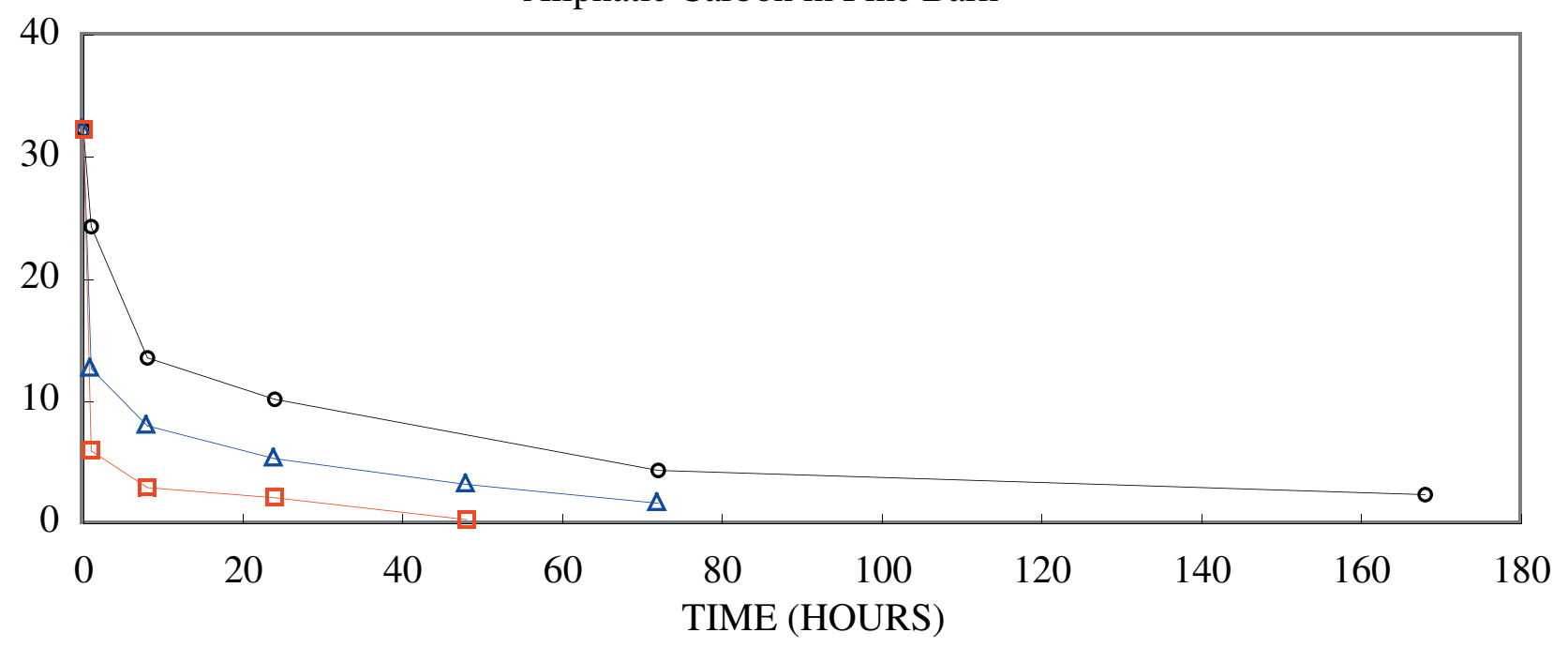

EXPLANATION

$\multimap 250$ Degrees Celsius $\quad \triangle 300$ Degrees Celsius $\square-\square 50$ Degrees Celsius

Figure 7. Calculated aromatic and aliphatic carbon content (grams carbon/100 grams starting material) in pine bark and chars at various heating times and temperatures. 
Table 9. Hydrogen/carbon atomic ratios and oxygen/carbon atomic ratios of material lost from char during heating intervals. $\left[{ }^{\circ} \mathrm{C}\right.$, degrees Celsius; --, no data. The oxygen/carbon ratios are in brackets.]

\begin{tabular}{|c|c|c|c|c|c|}
\hline \multirow[b]{2}{*}{$\begin{array}{l}\text { Time interval } \\
\text { (hours) }\end{array}$} & \multicolumn{5}{|c|}{ Preparation temperature } \\
\hline & $250^{\circ} \mathrm{C}$ & $300^{\circ} \mathrm{C}$ & $350^{\circ} \mathrm{C}$ & $400^{\circ} \mathrm{C}$ & $500^{\circ} \mathrm{C}$ \\
\hline \multicolumn{6}{|c|}{ Cellulose } \\
\hline $0-1$ & $1.0[0.7]$ & $2.9[1.6]$ & $2.6[1.4]$ & $2.4[1.27]$ & -- \\
\hline $1-8$ & $3.5[1.7]$ & $2.0[0.0]$ & $1.4[0.1]$ & -- & -- \\
\hline $8-24$ & $1.7[0.2]$ & $1.4[0.1]$ & $0.7[0.0]$ & $0.6[0.1]$ & -- \\
\hline $24-48$ & $0.6[0.1]$ & $0.0[0.0]$ & $0.4[0.2]$ & -- & -- \\
\hline $48-72$ & $0.8[0.2]$ & $0.3[0.2]$ & $0.3[0.3]$ & -- & -- \\
\hline \multicolumn{6}{|c|}{ Lignin } \\
\hline $0-1$ & -- & $1.6[0.5]$ & $1.9[0.5]$ & $1.7[0.4]$ & $1.6[0.5]$ \\
\hline $1-8$ & -- & $2.2[0.4]$ & $1.6[0.1]$ & $0.9[0.1]$ & $0.5[0.1]$ \\
\hline $8-24$ & $2.3[0.8]$ & {$[1.5]$} & $0.9[0.1]$ & $0.5[0.2]$ & -- \\
\hline $48-72$ & -- & $0.8[0.0]$ & $0.3[0.2]$ & -- & -- \\
\hline $0-1$ & $1.3[0.0]$ & $2.1[0.0]$ & $0.3[0.3]$ & -- & -- \\
\hline $72-144$ & $1.4[0.0]$ & -- & -- & -- & -- \\
\hline \multicolumn{6}{|c|}{ Poplar wood } \\
\hline $0-1$ & $2.3[1.0]$ & $2.3[1.1]$ & $2.1[1.0]$ & $2.0[0.9]$ & $1.9[0.9]$ \\
\hline $1-8$ & $2.1[0.8]$ & $1.7[0.5]$ & $0.8[0.2]$ & -- & -- \\
\hline $8-24$ & $8.4[1.7]$ & $0.9[0.0]$ & $0.5[0.1]$ & -- & -- \\
\hline $24-48$ & -- & $0.1[0.2]$ & $0.4[0.3]$ & -- & -- \\
\hline $48-72$ & $1.3[0.3]$ & $0.8[0.4]$ & -- & -- & -- \\
\hline $72-144$ & $0.4[0.2]$ & -- & -- & -- & -- \\
\hline \multicolumn{6}{|c|}{ Pine wood } \\
\hline $0-1$ & $2.3[0.9]$ & $2.7[1.1]$ & $2.1[0.9]$ & $2.0[0.8]$ & $1.8[0.7]$ \\
\hline $1-8$ & $3.5[1.4]$ & $1.6[0.4]$ & $0.8[0.0]$ & -- & -- \\
\hline $8-24$ & $2.2[0.5]$ & $0.8[0.1]$ & $0.4[0.3]$ & -- & -- \\
\hline $24-48$ & $1.0[0.4]$ & $0.8[0.3]$ & -- & -- & -- \\
\hline $48-72$ & -- & $0.0[0.2]$ & -- & -- & -- \\
\hline $72-168$ & 0.6 [1.6] & -- & -- & -- & -- \\
\hline \multicolumn{6}{|c|}{ Pine bark } \\
\hline $0-1$ & $2.7[1.2]$ & $2.5[1.2]$ & $2.4[1.1]$ & -- & -- \\
\hline $1-8$ & 3.1 [1.0] & $1.3[0.3]$ & $0.8[0.3]$ & -- & -- \\
\hline $8-24$ & $1.8[0.4]$ & $0.8[0.3]$ & $0.6[0.3]$ & -- & -- \\
\hline $24-48$ & -- & $0.7[0.2]$ & $0.6[0.3]$ & -- & -- \\
\hline $48-72$ & $0.9[0.3]$ & $0.4[0.4]$ & -- & -- & -- \\
\hline $72-168$ & $0.6[0.4]$ & -- & -- & -- & -- \\
\hline
\end{tabular}




\section{Surface Area and Porosity Changes}

The porosity and surface areas measurements for the chars examined in this study are given in tables 10-12. The surface areas are determined by the $\mathrm{N}_{2}$ BET method, which uses the nitrogen uptake in the partial pressure range of 0.05 to 0.3 in its calculation. If micropores (pores with a diameter less than $2 \mathrm{~nm}$ ) are present, they will fill in this partial pressure range, which will add to the nitrogen uptake on surfaces and confound the surface area calculation. Therefore, if microporosity is determined to be present by using the $t$-method, it is more accurate to examine the porosity directly than to rely on the apparent surface area calculated by the BET method. There is a 0.99 correlation between the micropore volume and the apparent BET surface area showing that the development of micropores is primarily responsible for the dramatic differences in apparent surface areas for these chars. The development of porosity can be used as a gage for structural changes occurring during the charring process; however, to be measured by nitrogen uptake, the pores must be accessible to nitrogen.

The cellulose used in this study had a micropore volume of less than the detection limit of $0.001 \mathrm{~cm}^{3} / \mathrm{g}$. At $250^{\circ} \mathrm{C}$, the micropore volume remained low, at or near the detection level for times up to 144 hours. At $300^{\circ} \mathrm{C}$, the micropore volume was below the detection level for 1 hour of heating but rose to $0.069 \mathrm{~cm}^{3} / \mathrm{g}$ when heated for 8 hours and to $0.080 \mathrm{~cm}^{3} / \mathrm{g}$ with heating for 24 hours. At $350^{\circ} \mathrm{C}$, the micropore volumes were $0.026,0.169$, and $0.235 \mathrm{~cm}^{3} / \mathrm{g}$ when heated for 1,8 , and 24 hours, respectively. At $400^{\circ} \mathrm{C}$, the micropore volumes were 0.070 and $0.308 \mathrm{~cm}^{3} / \mathrm{g}$ after heating for 1 , and 24 hours, respectively.

The lignin used in this study had a micropore volume of less than the detection limit. At $250^{\circ} \mathrm{C}$ for heating times up to 144 hours, and at $300^{\circ} \mathrm{C}$ for heating times up to 24 hours, the micropore volume remained below the detection level. At $300^{\circ} \mathrm{C}$ for heating times of 48 and 72 hours, the micropore volumes were 0.043 and $0.072 \mathrm{~cm}^{3} / \mathrm{g}$, respectively. At $350^{\circ} \mathrm{C}$, the micropore volumes were $<0.001,0.070$, and $0.222 \mathrm{~cm}^{3} / \mathrm{g}$ when heated for 1,8 , and 24 hours, respectively. At $400^{\circ} \mathrm{C}$, the micropore volumes were $<0.001,0.201$, and $0.306 \mathrm{~cm}^{3} / \mathrm{g}$ when heated for 1,8 , and 24 hours, respectively. At $500^{\circ} \mathrm{C}$, the micropore volumes were 0.079 , and $0.209 \mathrm{~cm}^{3} / \mathrm{g}$ when heated for 1 , and 8 hours, respectively.

Both cellulose and lignin show similar trends of increasing micropore volume with increasing heating time at a fixed temperature or increasing temperature at a fixed heating time, once the micropores start to develop. The point at which the microporosity develops is delayed for lignin compared to cellulose, which is consistent with the observation that cellulose decomposes at a lower temperature than lignin. The micropore volume for cellulose and lignin converge with time and are similar after 24 hours heating $\left(0.235\right.$ and $0.222 \mathrm{~cm}^{3} / \mathrm{g}$, respectively at $350^{\circ} \mathrm{C}$, and 0.308 and $0.306 \mathrm{~cm}^{3} / \mathrm{g}$, respectively at $400^{\circ} \mathrm{C}$ ), indicating that both are developing the same structure with charring.
Both charred pine and poplar wood behaved in a similar manner to charred cellulose as to the development of microporosity with time and temperature of charring. Both species had micropore volumes below or near the detection limit for times up to 144 hours at $250^{\circ} \mathrm{C}$, and for one hour heating at $300^{\circ} \mathrm{C}$. Both species showed rapid increase in microporosity between 1 and 8 hours heating at $300^{\circ} \mathrm{C}$. Both pine and poplar initially developed greater microporosity than cellulose, but both woods decreased in microporosity with prolonged heating (after 24 hours for pine, and 48 hours for poplar). After 24 hours heating at $350^{\circ} \mathrm{C}$, both pine and poplar had micropore volumes similar to cellulose and lignin $(0.244,0.257,0.235$, and $0.222 \mathrm{~cm}^{3} / \mathrm{g}$, respectively).

Pine bark showed similar trends as pine wood, but in all cases once microporosity was detected, charred pine bark had substantially less porosity than charred pine wood.

Porous carbons have been divided into two different categories: graphitizable carbon and nongraphitizable carbon (Byrne and Marsh, 1995). In both categories the carbon atoms are arranged in fused hexagonal rings similar to those in graphite. In graphite, the fused rings are arranged in continuous sheets that are stacked one on top of another to form a three-dimensional crystalline structure. In nongraphitizable carbon; however, the fused-ring sheets are stacked in small crystallites that are randomly oriented. Graphitizable porous carbons, in contrast to nongraphitizable porous carbon, will form a graphite-like material when heated to high temperatures. At elevated temperatures, the crystallites in graphitizable carbon reorient themselves such that the sheets in all of the crystallites are parallel one to another, thereby forming continuous sheets as in graphite. This reorientation destroys the porosity of the carbon. In nongraphitizable carbon this reorientation does not take place and porosity is preserved. The chars produced from wood and bark are nongraphitizable.

Franklin (1951) has shown that the reorientation of the crystallites in nongraphitizable carbons is impeded by "strong cross-linking between neighboring crystallites and by their random orientation." Franklin (1951) observed that nongraphitizable carbons form from materials that are high in oxygen. She postulated that as the graphite-like crystallites form in these high-oxygen materials, strong cross-links develop between the crystallites that maintain their random orientation. The random orientation of the crystallites leaves voids between the crystallites that constitute the porosity of the char.

Char from wood is considered to be nongraphitizing carbon. The wood or wood components do not contain measurable porosity but develop this porosity during charring. These materials do not develop porosity with charring at $250^{\circ} \mathrm{C}$ and for times less than 1 hour at $300^{\circ} \mathrm{C}$. The NMR and the FTIR spectra and the yield and elemental data show substantial change in the composition of the char occurring at $250^{\circ} \mathrm{C}$. These results show the formation of aromatic carbon from aliphatic carbon and the loss of mass. This lost mass has a higher hydrogen and oxygen content than the char. This is consistent with the loss of aliphatic components. It is possible that structural changes may be taking place that produce micropores, 
but these micropores may be filled with condensable degradation products or enclosed by impermeable material, which prevents nitrogen from entering the pore. If this is occurring, long charring times do not remove this material. The appearance of porosity does coincide with the loss of aromatic carbon, which indicates that porosity does not develop until after the conversion of aliphatic to aromatic carbon has ceased and aromatic carbon is being removed. This is consistent with the fused-ring aromatic carbon providing the rigid structure within which the micropores can develop. 
Table 10. Micropore volume in char after heating.

[Volume units: cubic centimeter per gram $\left(\mathrm{cm}^{3} / \mathrm{g}\right) ;{ }^{\circ} \mathrm{C}$, degrees Celsius; $<$, less than; --, no data]

\begin{tabular}{|c|c|c|c|c|c|}
\hline \multirow[b]{2}{*}{ Time (hours) } & \multicolumn{5}{|c|}{ Preparation temperature } \\
\hline & $250^{\circ} \mathrm{C}$ & $300^{\circ} \mathrm{C}$ & $350^{\circ} \mathrm{C}$ & $400^{\circ} \mathrm{C}$ & $500^{\circ} \mathrm{C}$ \\
\hline \multicolumn{6}{|c|}{ Cellulose (unheated <0.001) } \\
\hline 1 & $<0.001$ & 0.001 & 0.026 & 0.070 & -- \\
\hline 8 & $<0.001$ & 0.069 & 0.169 & -- & -- \\
\hline 24 & 0.001 & 0.080 & 0.235 & 0.308 & -- \\
\hline 48 & 0.002 & 0.048 & 0.212 & -- & -- \\
\hline 72 & 0.002 & 0.012 & 0.199 & -- & -- \\
\hline \multicolumn{6}{|c|}{ Lignin (unheated <0.001) } \\
\hline 1 & -- & $<0.001$ & $<0.001$ & $<0.001$ & 0.079 \\
\hline 8 & -- & $<0.001$ & 0.070 & 0.201 & 0.209 \\
\hline 24 & $<0.001$ & $<0.001$ & 0.222 & 0.306 & -- \\
\hline 48 & -- & 0.043 & 0.237 & -- & -- \\
\hline 72 & $<0.001$ & 0.072 & 0.225 & -- & -- \\
\hline 144 & $<0.001$ & -- & -- & -- & -- \\
\hline \multicolumn{6}{|c|}{ Poplar wood (unheated $<0.001$ ) } \\
\hline 1 & $<0.001$ & $<0.001$ & 0.060 & 0.067 & 0.138 \\
\hline 8 & 0.010 & 0.123 & 0.181 & -- & -- \\
\hline 24 & $<0.001$ & 0.140 & 0.257 & -- & -- \\
\hline 48 & -- & 0.143 & -- & -- & -- \\
\hline 72 & $<0.001$ & 0.052 & -- & -- & -- \\
\hline 144 & $<0.001$ & -- & -- & -- & -- \\
\hline \multicolumn{6}{|c|}{ Pine wood (unheated $<0.001$ ) } \\
\hline 1 & $<0.001$ & 0.002 & 0.119 & 0.143 & 0.253 \\
\hline 8 & $<0.001$ & 0.123 & 0.265 & -- & -- \\
\hline 24 & 0.001 & 0.205 & 0.244 & -- & -- \\
\hline 48 & 0.001 & 0.121 & -- & -- & -- \\
\hline 72 & -- & 0.084 & -- & -- & -- \\
\hline 168 & 0.001 & -- & -- & -- & -- \\
\hline \multicolumn{6}{|c|}{ Pine bark (unheated $<0.001$ ) } \\
\hline 1 & $<0.001$ & $<0.001$ & 0.012 & -- & -- \\
\hline 8 & $<0.001$ & 0.069 & 0.062 & -- & -- \\
\hline 24 & 0.001 & 0.093 & 0.110 & -- & -- \\
\hline 48 & -- & 0.112 & 0.098 & -- & -- \\
\hline 72 & 0.001 & 0.100 & -- & -- & -- \\
\hline 168 & 0.001 & -- & -- & -- & -- \\
\hline
\end{tabular}


Table 11. Total pore volume in char after heating.

[Volume units: cubic centimeter per gram $\left(\mathrm{cm}^{3} / \mathrm{g}\right) ;{ }^{\circ} \mathrm{C}$, degrees Celsius; $<$, less than; --, no data;

\begin{tabular}{|c|c|c|c|c|c|}
\hline \multirow[b]{2}{*}{ Time (hours) } & \multicolumn{5}{|c|}{ Preparation temperature } \\
\hline & $250^{\circ} \mathrm{C}$ & $300^{\circ} \mathrm{C}$ & $350^{\circ} \mathrm{C}$ & $400^{\circ} \mathrm{C}$ & $500^{\circ} \mathrm{C}$ \\
\hline \multicolumn{6}{|c|}{ Cellulose (unheated 0.005) } \\
\hline 1 & 0.005 & 0.003 & 0.034 & 0.087 & -- \\
\hline 8 & 0.004 & 0.089 & 0.210 & -- & -- \\
\hline 24 & 0.004 & 0.122 & 0.256 & 0.334 & -- \\
\hline 48 & 0.005 & 0.081 & 0.239 & -- & -- \\
\hline 72 & 0.005 & 0.020 & 0.225 & -- & -- \\
\hline \multicolumn{6}{|c|}{ Lignin (unheated 0.001) } \\
\hline 1 & -- & $<0.001$ & $<0.001$ & 0.002 & 0.095 \\
\hline 8 & -- & $<0.001$ & 0.077 & 0.216 & 0.232 \\
\hline 24 & $<0.001$ & $<0.001$ & 0.243 & 0.341 & -- \\
\hline 48 & -- & 0.048 & 0.260 & -- & -- \\
\hline 72 & $<0.001$ & 0.085 & 0.253 & -- & -- \\
\hline 144 & $<0.001$ & -- & -- & -- & -- \\
\hline \multicolumn{6}{|c|}{ Poplar wood (unheated 0.003) } \\
\hline 1 & 0.002 & 0.002 & 0.069 & 0.077 & 0.163 \\
\hline 8 & 0.014 & 0.145 & 0.204 & -- & -- \\
\hline 24 & 0.002 & 0.167 & 0.291 & -- & -- \\
\hline 48 & -- & 0.172 & -- & -- & -- \\
\hline 72 & 0.002 & 0.088 & -- & -- & -- \\
\hline 144 & 0.002 & -- & -- & -- & -- \\
\hline \multicolumn{6}{|c|}{ Pine wood (unheated 0.004) } \\
\hline 1 & 0.002 & 0.005 & 0.133 & 0.189 & 0.286 \\
\hline 8 & 0.002 & 0.140 & 0.297 & -- & -- \\
\hline 24 & 0.002 & 0.227 & 0.295 & -- & -- \\
\hline 48 & 0.002 & 0.149 & -- & -- & -- \\
\hline 72 & -- & 0.106 & -- & -- & -- \\
\hline 168 & 0.002 & -- & -- & -- & -- \\
\hline \multicolumn{6}{|c|}{ Pine bark (unheated 0.004) } \\
\hline 1 & 0.001 & 0.002 & 0.016 & -- & -- \\
\hline 8 & 0.002 & 0.081 & 0.079 & -- & -- \\
\hline 24 & 0.002 & 0.112 & 0.142 & -- & -- \\
\hline 48 & -- & 0.142 & 0.158 & -- & -- \\
\hline 72 & 0.003 & 0.143 & -- & -- & -- \\
\hline 168 & 0.004 & -- & -- & -- & -- \\
\hline
\end{tabular}


Table 12. Surface area in char after heating.

[Area units: square meter per gram $\left(\mathrm{m}^{2} / \mathrm{g}\right) ;{ }^{\circ} \mathrm{C}$, degrees Celsius; <, less than; --, no data;]

\begin{tabular}{|c|c|c|c|c|c|}
\hline \multirow[b]{2}{*}{ Time (hours) } & \multicolumn{5}{|c|}{ Preparation temperature } \\
\hline & $250^{\circ} \mathrm{C}$ & $300^{\circ} \mathrm{C}$ & $350^{\circ} \mathrm{C}$ & $400^{\circ} \mathrm{C}$ & $500^{\circ} \mathrm{C}$ \\
\hline \multicolumn{6}{|c|}{ Cellulose (unheated 2.14) } \\
\hline 1 & 1.55 & 2.88 & 54.9 & 147 & -- \\
\hline 8 & 3.06 & 145 & 362 & -- & -- \\
\hline 24 & 3.59 & 189 & 461 & 602 & -- \\
\hline 48 & 3.99 & 122 & 422 & -- & -- \\
\hline 72 & 3.73 & 29.7 & 397 & -- & -- \\
\hline \multicolumn{6}{|c|}{ Lignin (unheated <1) } \\
\hline 1 & -- & $<1$ & $<1$ & 2.03 & 162 \\
\hline 8 & -- & $<1$ & 138 & 394 & 418 \\
\hline 24 & $<1$ & $<1$ & 440 & 614 & -- \\
\hline 48 & -- & 84.5 & 471 & -- & -- \\
\hline 72 & $<1$ & 146 & 454 & -- & -- \\
\hline 144 & $<1$ & -- & -- & -- & -- \\
\hline \multicolumn{6}{|c|}{ Poplar wood (unheated 1.46) } \\
\hline 1 & $<1$ & 1.40 & 136 & 172 & 354 \\
\hline 8 & 21.7 & 250 & 359 & -- & -- \\
\hline 24 & 2.20 & 288 & 509 & -- & -- \\
\hline 48 & -- & 293 & -- & -- & -- \\
\hline 72 & 2.17 & 133 & -- & -- & -- \\
\hline 144 & 2.10 & -- & -- & -- & -- \\
\hline \multicolumn{6}{|c|}{ Pine wood (unheated 2.00) } \\
\hline 1 & $<1$ & 4.90 & 214 & 301 & 501 \\
\hline 8 & 1.20 & 246 & 517 & -- & -- \\
\hline 24 & 2.00 & 401 & 486 & -- & -- \\
\hline 48 & 1.00 & 211 & -- & -- & -- \\
\hline 72 & -- & 176 & -- & -- & -- \\
\hline 168 & 2.11 & -- & -- & -- & -- \\
\hline \multicolumn{6}{|c|}{ Pine bark (unheated 2.22) } \\
\hline 1 & $<1$ & 1.00 & 24.2 & -- & -- \\
\hline 8 & 1.32 & 140 & 127 & -- & -- \\
\hline 24 & 2.68 & 190 & 226 & -- & -- \\
\hline 48 & -- & 234 & 213 & -- & -- \\
\hline 72 & 3.40 & 216 & -- & -- & -- \\
\hline 168 & 3.03 & -- & -- & -- & -- \\
\hline
\end{tabular}




\section{Summary}

The purpose of the study described in this report was to examine the compositional and structural changes occurring during the thermal degradation of wood and wood components. Pine and poplar wood, pine bark, and purified cellulose and lignin were studied. Charring temperatures from $250^{\circ} \mathrm{C}$ to $500^{\circ} \mathrm{C}$ were used with charring times from 1 hour to 168 hours. The two major components in wood are cellulose and lignin, with cellulose making up approximately two thirds and lignin making up about one third of the mass. The changes that each of these two components undergo during heating allow us to better understand the changes that take place when wood and bark are heated.

Cellulose showed substantial weight loss with charring at $250^{\circ} \mathrm{C}$, with 60 percent loss between 1 and 8 hours of heating. At higher temperatures, most of the weight loss occurred within the first hour of heating. Lignin char retained 80 percent of its original mass when heated at $250^{\circ} \mathrm{C}$ for 144 hours, indicating that very little degradation of lignin has occurred. The percentage char remaining after heating of lignin for 72 hours at $300^{\circ} \mathrm{C}$ was approximately 60 percent. Higher temperatures increased the rate of weight loss with 80 to 85 percent loss after 24 hours at $400^{\circ} \mathrm{C}$ and 8 hours at $500^{\circ} \mathrm{C}$. Both pine and poplar wood showed mass loss comparable to cellulose with charring at $250^{\circ} \mathrm{C}$ and $300^{\circ} \mathrm{C}$. At $350^{\circ} \mathrm{C}$, both woods showed greater mass loss than cellulose for heating times in excess of 8 hours. Pine bark showed slightly less mass loss than pine wood at all charring times and temperatures. This difference became more pronounced as the temperature increased to $300^{\circ} \mathrm{C}$ and $350^{\circ} \mathrm{C}$.

At $250^{\circ} \mathrm{C}$ for heating times of 1 hour, neither the ${ }^{13} \mathrm{C}$ nuclear magnetic resonance nor Fourier Transform Infrared spectra showed much change in composition for any of the materials tested. For longer heating at $250^{\circ} \mathrm{C}$, cellulose showed substantial decomposition while lignin showed little degradation. The changes in cellulose indicate the loss of aliphatic components and the formation of aromatic components. For the wood and bark samples, heating for 8 hours at $250^{\circ} \mathrm{C}$ showed the aliphatic components reduced, the aromatic content increased, and the lignin signature more pronounced. After 24 hours of heating at $250^{\circ} \mathrm{C}$ for the wood and bark samples, the lignin signature and the aliphatic components were greatly reduced, and aromatic carbon remained as the primary residual carbon. At $300^{\circ} \mathrm{C}$, degradation of lignin was apparent from NMR and IR spectra, with loss of aliphatic components progressing for 72 hours. The degradation of cellulose, wood, and bark occurred more rapidly at $300^{\circ} \mathrm{C}$ than at $250^{\circ} \mathrm{C}$. Temperatures higher than $300^{\circ} \mathrm{C}$ caused acceleration of the degradation of all the test materials.

The elemental analyses for carbon, hydrogen, and oxygen of uncharred and charred materials showed an increase in percentage carbon, a decrease of percentage hydrogen, and a decrease in percentage oxygen, with charring for all tested materials. Analysis of the hydrogen/carbon and oxygen/car- bon atomic ratios for the residual char and for the material lost from the char showed that hydrogen and oxygen were lost more rapidly than carbon from the char during the initial periods of charring. This is consistent with the initial loss of aliphatic carbon, either to volatile degradation products or the conversion of aliphatic carbon to fused aromatic rings.

Combining the fraction of initial mass remaining with the fraction carbon and percentage aromatic or aliphatic carbon was done to calculate the mass of aromatic or aliphatic carbon remaining per $100 \mathrm{~g}$ of starting material. This analysis showed that at $250^{\circ} \mathrm{C}$, all materials tested lost aliphatic carbon for all time intervals, while aromatic carbon initially increased and then remained relatively constant with little loss. At higher temperatures, the loss of aliphatic carbon was accelerated for all test materials, and after an initial period of aromatic carbon increase, there was loss of aromatic carbon.

No porosity developed in any of the tested materials when charred at $250^{\circ} \mathrm{C}$. Porosity appeared for cellulose, wood, and bark samples when charred at $300^{\circ} \mathrm{C}$ between 1 and 8 hours. Porosity appeared in lignin when charred at $300^{\circ} \mathrm{C}$ between 24 and 48 hours. For a fixed charring time, porosity generally increased with charring temperature. For a fixed charring temperature, porosity generally increased to a maximum and then decreased.

The relation between structural changes, as measured by the development of porosity and the observed compositional changes, was not well defined for any single parameter measured. Decomposition, as measured by mass loss and decrease in $\mathrm{H} / \mathrm{C}$ and $\mathrm{O} / \mathrm{C}$ ratios and changes in IR and NMR spectra occurred at temperatures of $250^{\circ} \mathrm{C}$ and above for cellulose, pine and poplar wood, and pine bark, and at temperatures above $300^{\circ} \mathrm{C}$ for lignin. These changes in composition varied continuously with time, while the increase in porosity appeared suddenly and showed a maximum, after which porosity decreased with time. The measure of aromatic carbon mass as determined by NMR spectra, elemental composition, and mass loss, provided the best predictor of changes in porosity. The charring process appeared to initially create aromatic carbon from aliphatic carbon, forming fused ring structures, which provide a matrix in which microporosity can develop. It was not until the total mass of aromatic carbon started to decrease that porosity began to develop. The formation of fused-ring structures occurs at $250^{\circ} \mathrm{C}$ for cellulose, wood, and bark, but no porosity develops, even for long heating times that would be expected to volatilize degradation products that could be filling pores. This indicates that it is the loss of aromatic carbon that creates the micropores in the fused-ring matrix. There was some indication that prolonged heating may cause fused-ring structures to coalesce and reduce porosity. 


\section{Literature Cited}

Allan, G.G., 1971, Modification reactions, in Sarkanen, K.V., and Ludwig, C.H., eds., Lignins-Occurrence, formation, structure and reactions: New York, Wiley-Interscience, p. 511-573.

Amen-Chen, Carlos, Pakdel, Hooshang, and Roy, Christian, 2001, Production of monomeric phenols by thermochemical conversion of biomass-A review: Bioresource Technology, v. 79 , p. $277-299$.

Baldock, J.A., and Smernik, R.J., 2002, Chemical composition and bioavailability of thermally altered Pinus resinosa (Red pine) wood: Organic Geochemistry, v. 33, p. 1093-1109.

Brunauer, S., Emmett P.H., and Teller, E., 1938, Adsorption of gases in multimolecular layers: Journal of the American Chemical Society, v. 60, p. 309-319.

Byrne, J.F., and Marsh, Harry, 1995, Introductory overview, in Patrick, J.W., ed., Porosity in carbons-Characterization and applications: New York, Halsted Press, p. 2-48.

Cambardella, C.A., and Elliot, E.T., 1992, Particulate soil organic-matter changes across a grassland cultivation sequence: Soil Science Society of America Journal, v. 56, p. 777-783.

Chen, Runying, and Jakes, K.A., 2002, Effects of pressing on the infrared spectra of single cotton fibers: Applied Spectroscopy, v. 56, p. 646-650.

Colthup, N.B., Daly, L.H., and Wiberley, S.E., 1990, Introduction to infrared and raman spectroscopy: Boston, Academic Press, 547 p.

Croteau, Rodney, Kutchan, T.M., and Lewis, N.G., 2000, Natural products (secondary metabolites), in Buchanan, B.B., Gruissem, Wilhelm, and Jones, R.L., eds., Biochemistry \& molecular biology of plants: Rockville, Maryland, American Society of Plant Physiologists (distributed by John Wiley \& Sons, Inc.), p. 1250-1318.

de Boer, J.H., Lippens, B.C., Linsen, B.G., Broekhoff, J.C.P., van den Heuvel, A., and Osinga, T.J., 1966, The $t$-curve of multilayer $\mathrm{N}_{2}$-adsorption: Journal of Colloid and Interface Science, v. 21, p. 405-414.

Faix, O., 1991, Classification of lignins from different botanical origins by FTIR spectroscopy: Holzforschung, v. 45, Supplement, p. 21-27.

Franklin, R.E., 1951, Crystallite growth in graphitizing and non-graphitizing carbons: Proceedings of the Royal Society, v. A209, p. 196-218.
Gelinas, Yves, Prentice, K.M., Baldock, J.A., and Hedges, J.J., 2001, An improved thermal oxidation method for the quantification of soot/graphitic black carbon in sediments and soils: Environmental Science and Technology, v. 35, p. 3519-3525.

Gil, A.M., Lopes, M., Rocha, J., and Neto, C.P., 1997, A ${ }^{13} \mathrm{C}$ solid state nuclear magnetic resonance spectroscopic study of cork cell wall structure-The effect of suberin removal: International Journal of Biological Macromolecules, v. 20, p. 293-305.

Glaser, Bruno, Haumaier, Ludwig, Guggenberger, Georg, and Zech, Wolfgang, 2001, The "Terra Preta" phenomenon: A model for sustainable agriculture in the humid tropics: Naturwissenschaften, v. 88 , p. 37-41.

González-Vila, F.J., Tinoco, Pilar, Almendros, Gonzalo, and Martin, Francisco, 2001, Pyrolysis-GC-MS analysis of the formation and degradation stages of charred residues from lignocellulosic biomass: Journal of Agricultural and Food Chemistry, v. 49, p. 1128-1131.

Hassi, H.Y., Aoyama, M., Tai, D., Chen, C.-L., and Gratzl, J.S., 1987, Substituent effects on ${ }^{13} \mathrm{C}$ chemical shifts of aromatic carbons in B-O-4 and B-5 type lignin model compounds: Journal of Wood Chemistry and Technology, v. 7, $555-581$.

Haw, J.F., and Schultz, T.P., 1985, Carbon-13 CP/MAS NMR and FTIR study of low-temperature lignin pyrolysis: Holtzforschung, v. 39, p. 289-296.

Jorge, Miguel, Schumacher, Christian, and Seaton, N.A., 2002, Simulation study of the effect of the chemical heterogeneity of activated carbon on water adsorption: Langmuir, v. 18, p. 9296-9306.

Karapanagiotti, H.K., Kleineidam, Sybille, Sabatini, D.A., Grathwohl, Peter, and Ligouis, Bertrand, 2000, Impacts of heterogeneous organic matter on phenanthrene sorption: Equilibrium and kinetic studies with aquifer material: Environmental Science and Technology, v. 34, p.406-414

Larsson, P.T., Hult, E.-L., Wickholm, Kristina, Pettersson, Erik, and Iversen, Tommy, 1999, CP/MAS ${ }^{13} \mathrm{C}-\mathrm{NMR}$ spectroscopy applied to structure and interaction studies of cellulose I: Solid State Nuclear Magnetic Resonance, v. 15, p. 31-40.

Pastorova, Ivana, Botto, R.E., Arisz, P.W., and Boon, J.J., 1994, Cellulose char structure: A combined analytical PyGC-MS, FTIR, and NMR study: Carbohydrate Research, v. 262 , p. $27-47$.

Patrick, J.W., 1995, Porosity in carbons-Characteristics and applications: New York, Halsted Press, 331 p. 
Pradhan, B.K., and Sandle, N.K., 1999, Effect of different oxidizing agent treatments on the surface properties of activated carbons: Carbon, v. 37, p. 1323-1332.

Schmidt, M.W.J., Skjemstad, J.O., Gehrt, E., and KogelKnabner, I., 1999, Charred organic carbon in German chernozemic soils: European Journal of Soil Science, v. 50, p. $351-365$.

Shafizadeh, Fred, 1982, Chemistry of pyrolysis and combustion of wood, in Sarkanen, K.V., Tillman, D.A., and Jahns, E.C., eds., Progress in biomass conversion: London, Academic Press, p. 51-76.

Simpson, M.J., and Hatcher, P.G., 2004a, Determination of black carbon in natural organic matter by chemical oxidation and solid-state ${ }^{13} \mathrm{C}$ nuclear magnetic resonance spectroscopy: Organic Geochemistry, v. 35, p. 923-935.

Simpson, M.J., and Hatcher, P.G., 2004b, Overestimates of black carbon in soils and sediments: Naturwissenschaften, v. 91 , p. $436-440$.

Skjemstad, J.O., Clarke, P., Taylor, J.A., Oades, J.M., and McClure, S.G., 1996, The chemistry and nature of protected carbon in soil: Australian Journal of Soil Research, v.32, p. 251-276.

Skjemstad, J.O., Reicosky, D.C., Wilts, A.R., and McGowan, J.A., 2002, Charcoal carbon in U.S. agricultural soils: Soil Science Society of America Journal, v. 66, p. 1249-1255.

Song, Jianzhong, Peng, Piang' an, and Huang, Weilin, 2002, Black carbon and kerogen in soils and sediments. 1 Quantification and characterization: Environmental Science and Technology, v. 36, p. 3960-3967.

ten Have, Rimko, and Teunissen, P.J.M., 2001, Oxidative mechanisms involved in lignin degradation by white-rot fungi: Chemical Reviews, v. 101, p. 3397-3413.

Wershaw, R.L., Leenheer, J.A., and Kennedy, K.R., 1998, Use of ${ }^{13} \mathrm{C}$ NMR and FTIR for elucidation of degradation pathways during natural litter decomposition and composting. III. Characterization of leachated from different types of leaves, in Davies, G., and Ghabbour, E.A., Humic substances structures, properties, and uses: Cambridge, England, Royal Society of Chemistry, p. 47-60.

Williams, P.T., and Besler, Serpil, 1996, The influence of temperature and heating rate on the slow pyrolysis of biomass: Renewable Energy, v. 7, p. 233-250.

Yang, Shaobin, Hu, Haoquan, and Chen, Guohua, 2002, Preparation of carbon adsorbents with high surface area and a model for calculating surface area: Carbon, v. 40, p. 277-284. 


\section{Appendix A. Replicate Charring and Analyses}

Code for sample identification:

First letter identifies the starting material.

$$
\begin{aligned}
& P=\text { pine wood } \\
& B=\text { pine bark } \\
& C=\text { cellulose } \\
& L=\text { lignin }
\end{aligned}
$$

The next three-digit number identifies charring temperature

Last group of numbers identifies charring time in hours

Parameters measured:

Yield is the percentage char remaining.

S.A. is the surface area in square meters per gram $\left(\mathrm{m}^{2} / \mathrm{g}\right)$.

TPV is the total pore volume in cubic centimeters per gram $\left(\mathrm{cm}^{3} / \mathrm{g}\right.$.

Abbreviations and Symbols:

Std. Dev. is the standard deviation

$<$ is less than

-- is no data 
Table A-1. Replicates for pine wood samples.

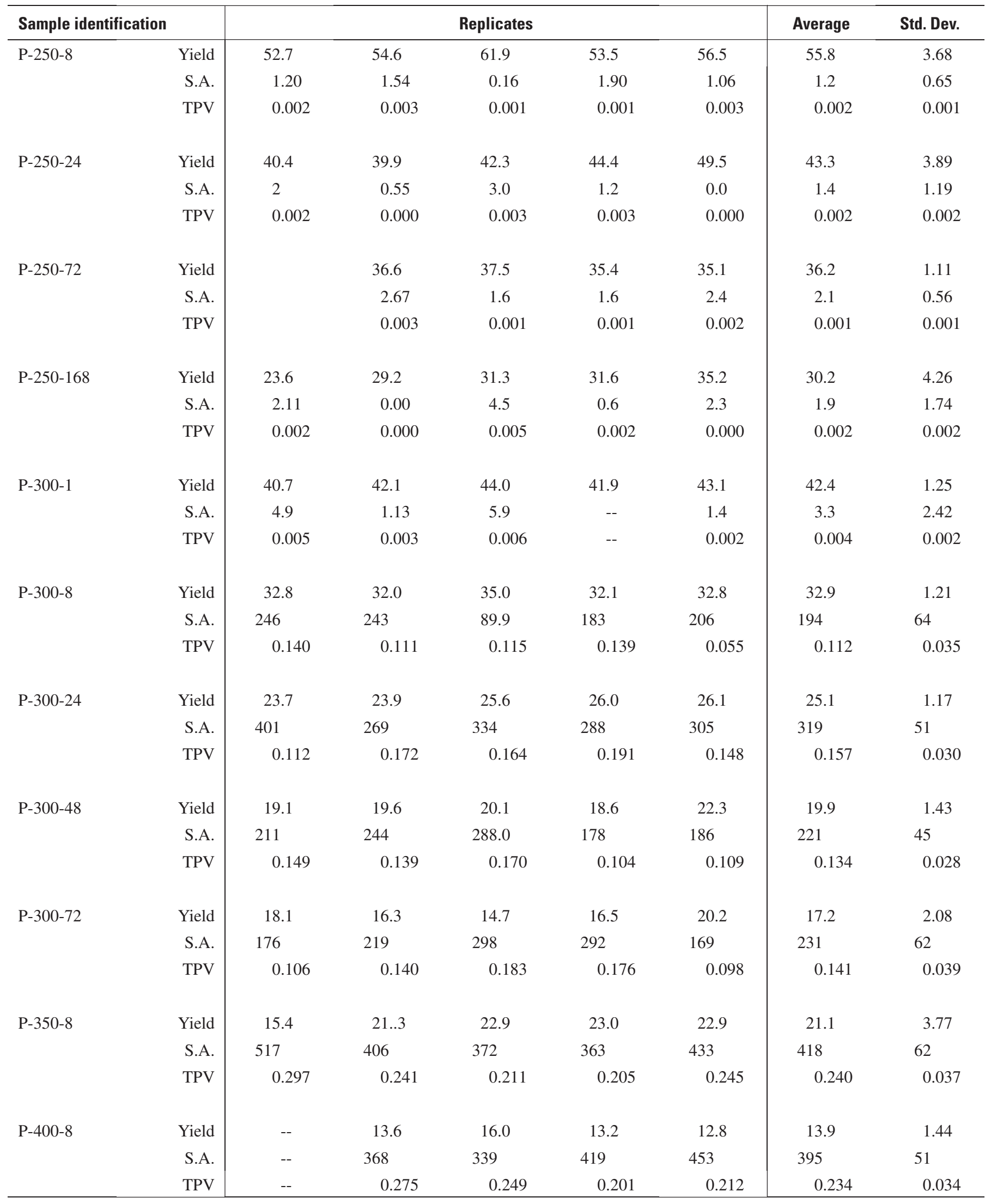


Table A-2. Replicates for pine bark samples.

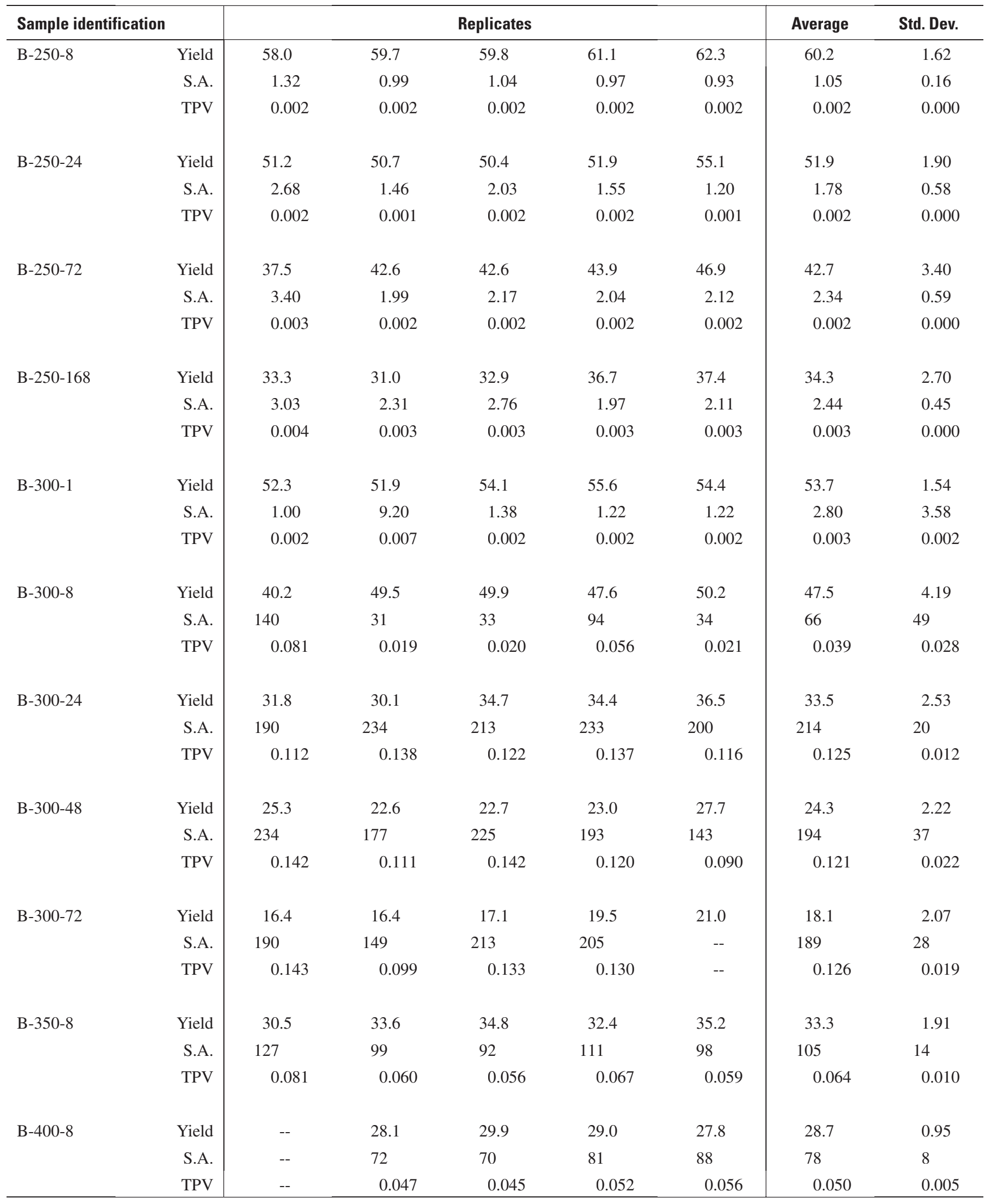


Table A-3. Replicates for cellulose samples.

\begin{tabular}{|c|c|c|c|c|c|c|c|c|}
\hline \multicolumn{2}{|c|}{ Sample identification } & \multicolumn{5}{|c|}{ Replicates } & \multirow{2}{*}{$\begin{array}{c}\text { Average } \\
44.1\end{array}$} & \multirow{2}{*}{$\begin{array}{c}\text { Std. Dev. } \\
6.24\end{array}$} \\
\hline C-250-8 & Yield & 40.1 & 39.6 & 40.5 & 46.2 & 54.2 & & \\
\hline & S.A. & 3.23 & 4.15 & 3.01 & & 1.86 & 3.06 & 0.94 \\
\hline & TPV & 0.005 & 0.005 & 0.004 & & 0.004 & 0.004 & 0.001 \\
\hline \multirow[t]{3}{*}{ C-250-24 } & Yield & 33.4 & 34.3 & 34.7 & 37.0 & 38.2 & 35.5 & 2.00 \\
\hline & S.A. & 3.59 & 3.11 & 3.87 & 3.20 & 3.46 & 3.45 & 0.31 \\
\hline & TPV & 0.004 & 0.004 & 0.005 & 0.005 & 0.005 & 0.005 & 0.000 \\
\hline \multirow[t]{3}{*}{ C-250-72 } & Yield & 31.2 & 30.7 & 31.0 & 31.1 & 32.8 & 31.4 & 0.83 \\
\hline & S.A. & 3.73 & 3.13 & 3.54 & 3.41 & 3.21 & 3.40 & 0.24 \\
\hline & TPV & 0.005 & 0.005 & 0.005 & 0.005 & 0.005 & 0.005 & 0.000 \\
\hline \multirow[t]{3}{*}{ C-250-168 } & Yield & -- & 28.7 & 28.6 & 28.8 & 29.8 & 29.0 & 0.56 \\
\hline & S.A. & -- & 3.10 & 2.99 & 2.99 & 3.24 & 3.08 & 0.12 \\
\hline & TPV & -- & 0.005 & 0.006 & 0.007 & 0.007 & 0.006 & 0.001 \\
\hline \multirow[t]{3}{*}{ C-300-8 } & Yield & 30.9 & 31.6 & 30.9 & 30.4 & 29.9 & 30.7 & 0.63 \\
\hline & S.A. & 147 & 137 & 153 & 148 & 142 & 145.4 & 6.11 \\
\hline & TPV & 0.087 & 0.081 & 0.094 & 0.091 & 0.090 & 0.089 & 0.005 \\
\hline \multirow[t]{3}{*}{ C-300-24 } & Yield & 24.7 & 27.1 & 27.1 & 27.9 & 29.0 & 27.2 & 1.58 \\
\hline & S.A. & 189 & 197 & 270 & 204 & 161 & 204. & 40.3 \\
\hline & TPV & 0.122 & 0.122 & 0.165 & 0.126 & 0.117 & 0.130 & 0.020 \\
\hline \multirow[t]{3}{*}{ C-300-48 } & Yield & 23.0 & 23.6 & 24.2 & 23.5 & 25.0 & 23.9 & 0.77 \\
\hline & S.A. & 122 & 18.5 & 63.8 & 31.7 & 48.20 & 56.8 & 40.2 \\
\hline & TPV & 0.081 & 0.002 & 0.050 & 0.023 & 0.044 & 0.040 & 0.030 \\
\hline \multirow[t]{3}{*}{ C-300-72 } & Yield & 20.9 & 22.4 & 23.1 & 22.5 & -- & 22.2 & 0.94 \\
\hline & S.A. & 29.7 & 17.7 & 45.5 & 57.3 & 25.2 & 35.1 & 16.1 \\
\hline & TPV & 0.020 & 0.014 & 0.034 & 0.084 & 0.020 & 0.034 & 0.028 \\
\hline \multirow[t]{3}{*}{ C-350-8 } & Yield & 22.8 & 24.5 & 24.2 & 22.1 & 23.7 & 23.5 & 1.00 \\
\hline & S.A. & 338 & 347 & 342 & 401 & 384 & 362 & 28.3 \\
\hline & TPV & 0.191 & 0.202 & 0.200 & 0.232 & 0.223 & 0.210 & 0.017 \\
\hline \multirow[t]{3}{*}{ C-400-8 } & Yield & -- & 19.25 & 19.7 & 17.5 & 19.4 & 19.0 & 0.99 \\
\hline & S.A. & -- & 420 & 414 & 464 & 410 & 427 & 25.0 \\
\hline & TPV & -- & 0.243 & 0.240 & 0.267 & 0.237 & 0.247 & 0.014 \\
\hline
\end{tabular}


Table A-4. Replicates for lignin samples.

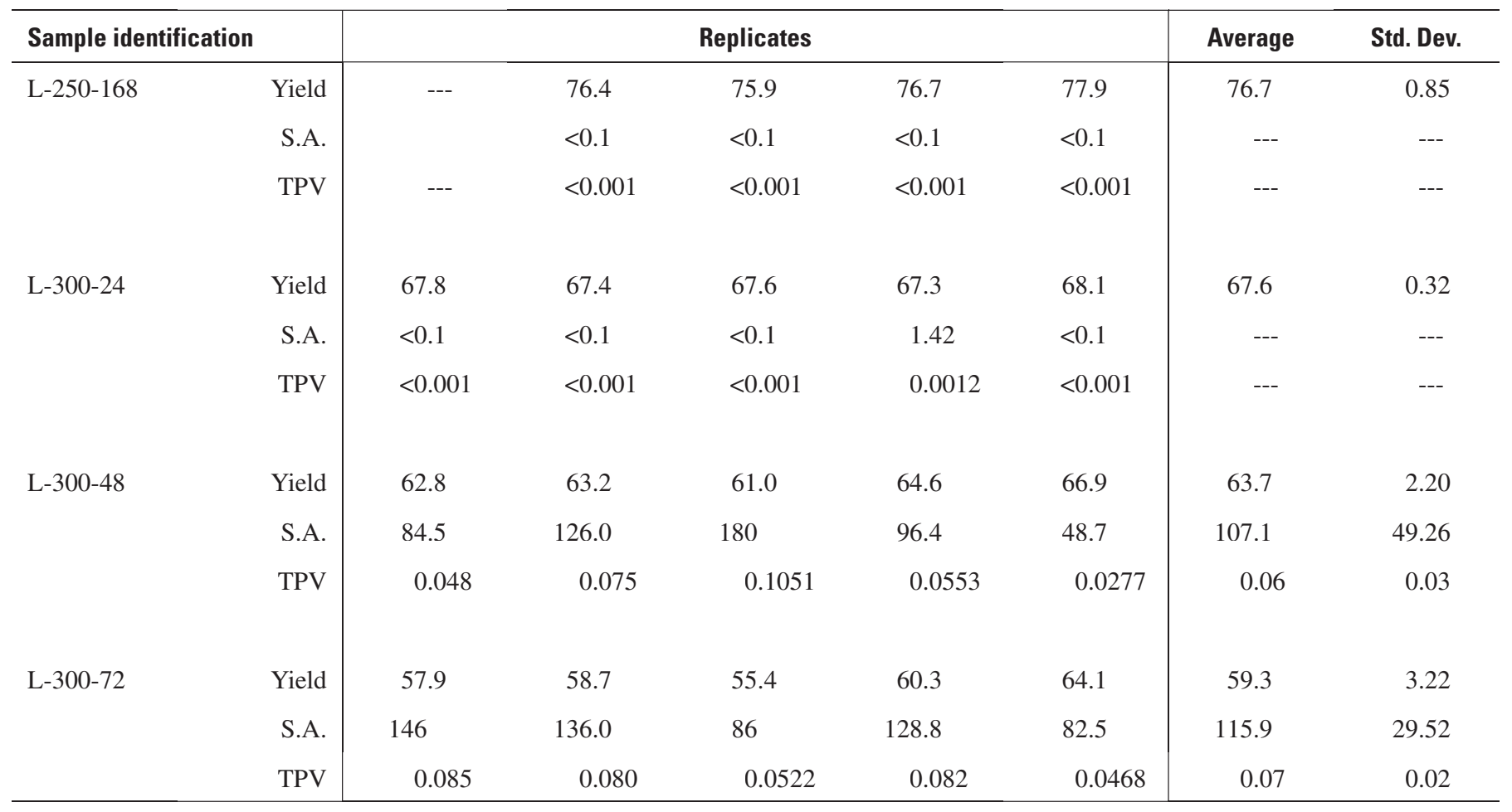




\section{Appendix B. Fourier Transform Infrared (FTIR) Spectra}

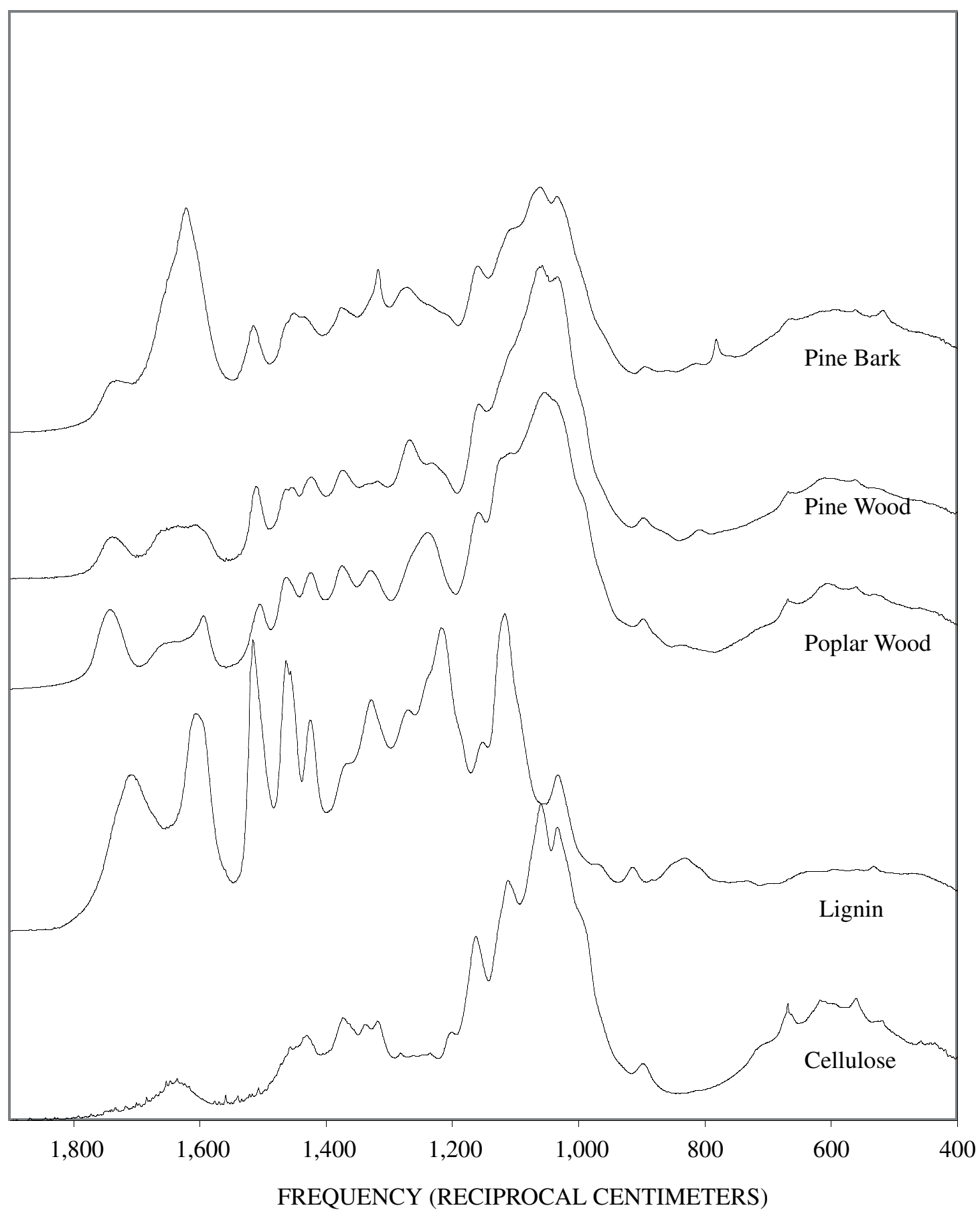

Figure B-1. Fourier Transform Infrared (FTIR) spectra of unheated cellulose, lignin, pine wood, poplar wood and pine bark. 


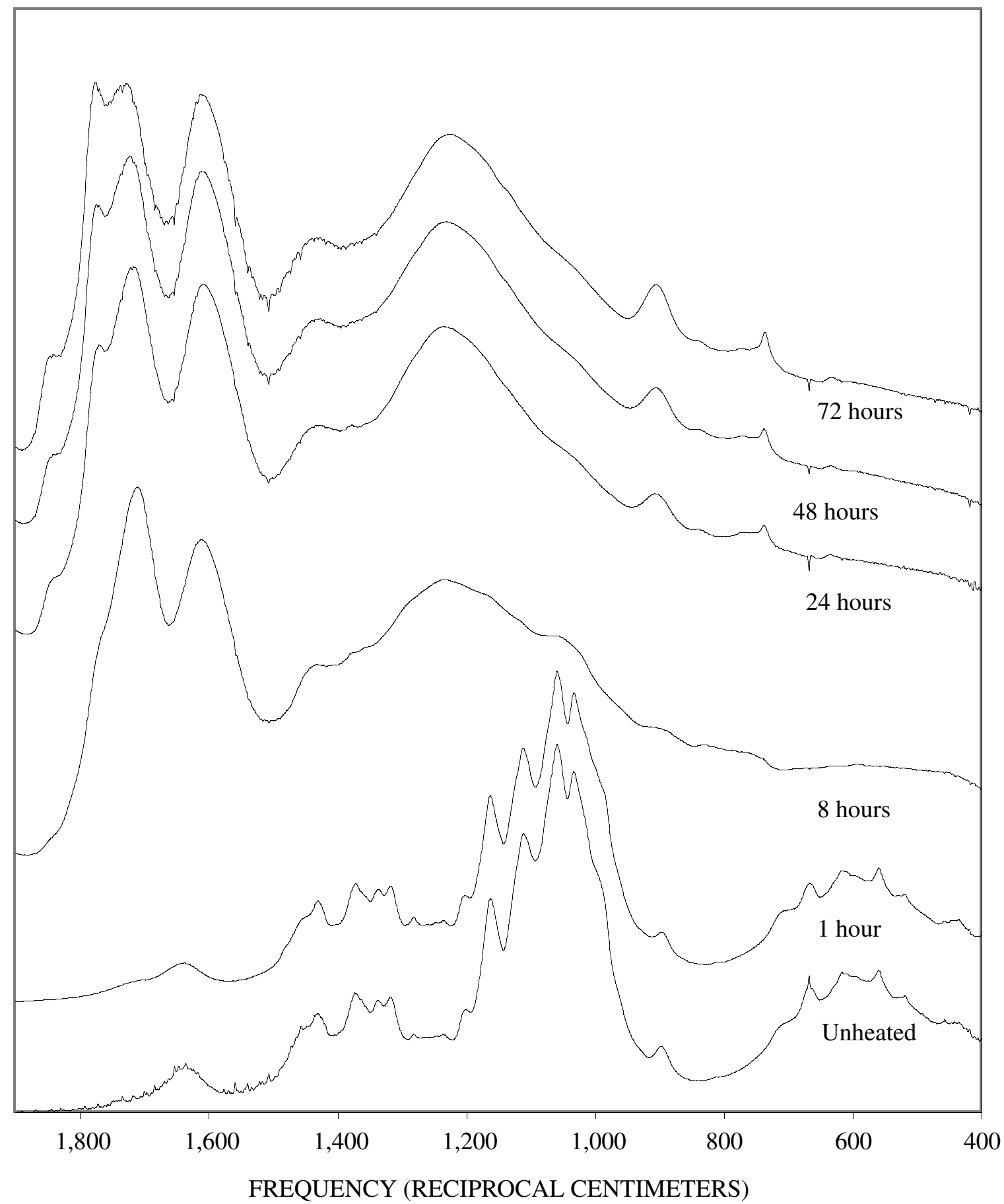

Figure B-2. Fourier Transform Infrared (FTIR) spectra of cellulose heated at $250^{\circ} \mathrm{C}$ for various times. 


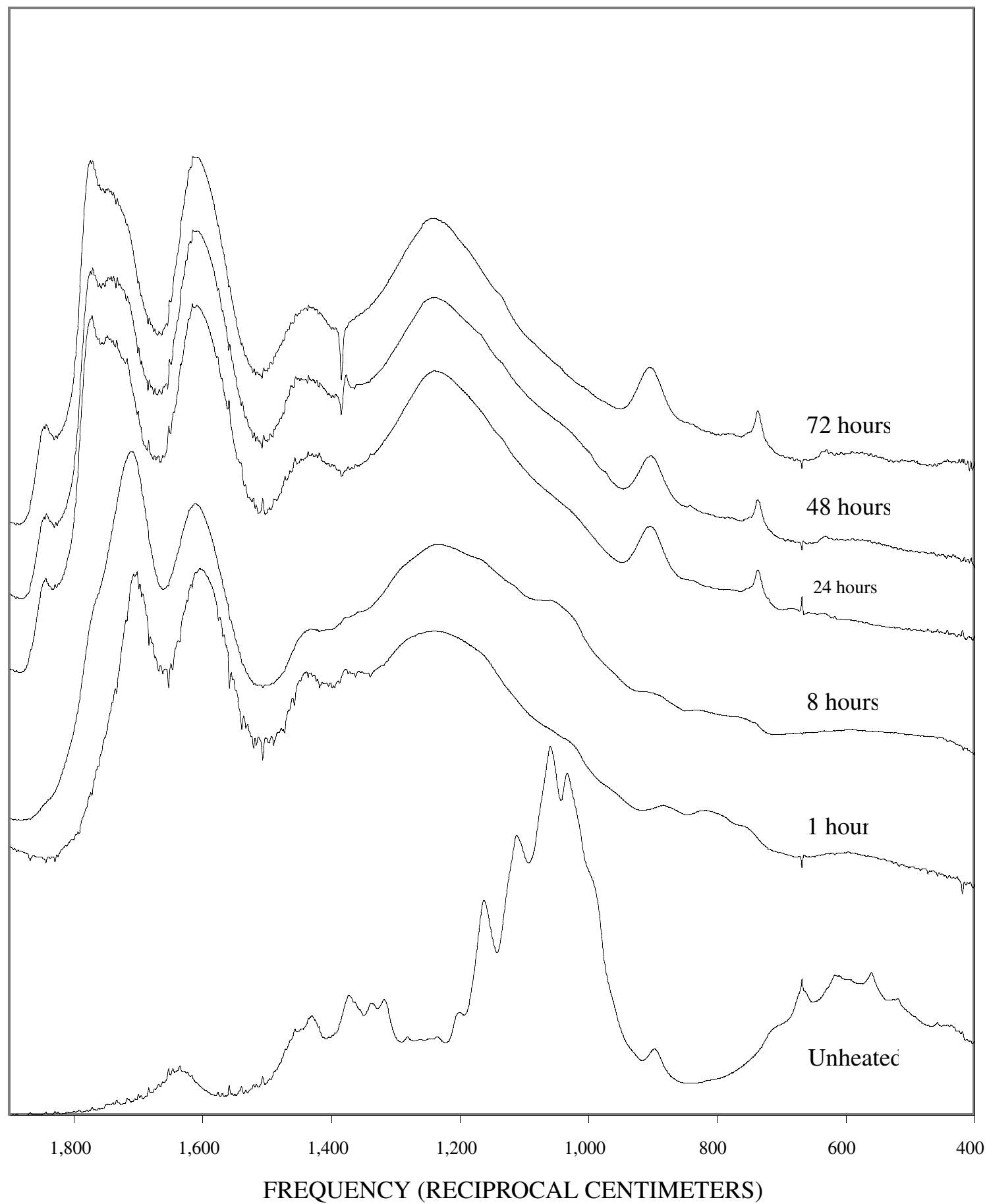

Figure B-3. Fourier Transform Infrared (FTIR) spectra of cellulose heated at $300^{\circ} \mathrm{C}$ for various times. 


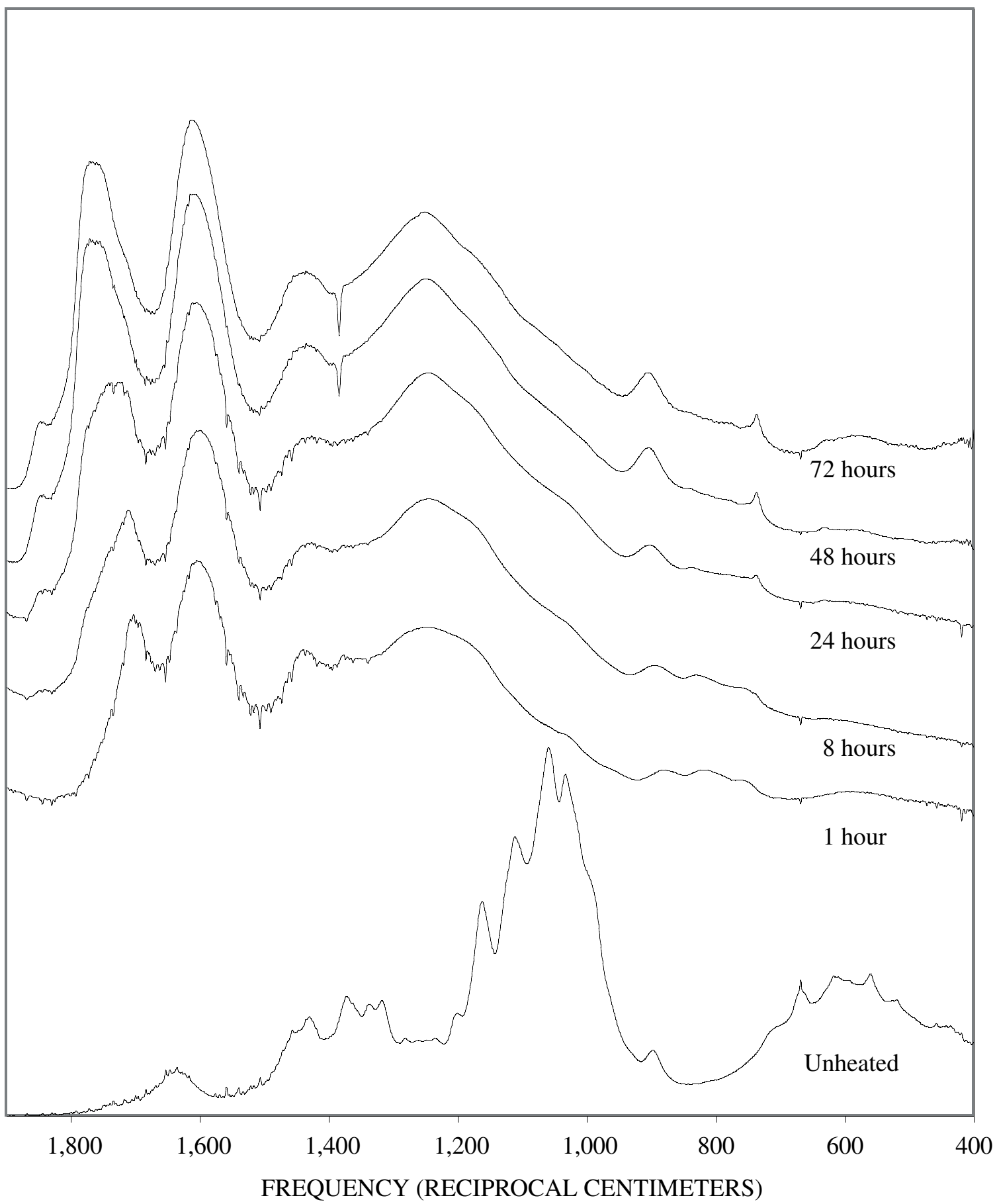

Figure B-4. Fourier Transform Infrared (FTIR) spectra of cellulose heated at $350^{\circ} \mathrm{C}$ for various times. 


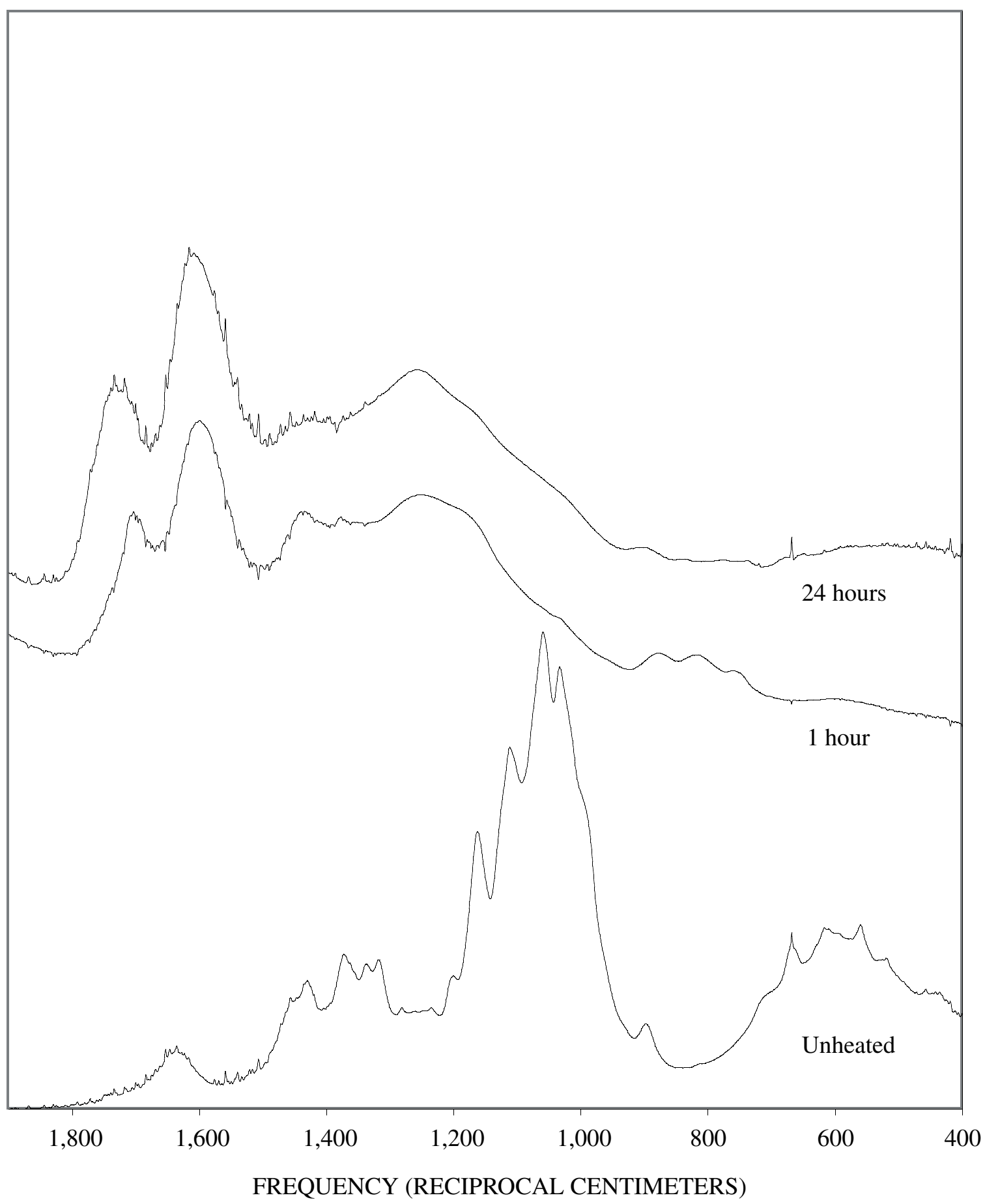

Figure B-5. Fourier Transform Infrared (FTIR) spectra of cellulose heated at $400^{\circ} \mathrm{C}$ for various times. 


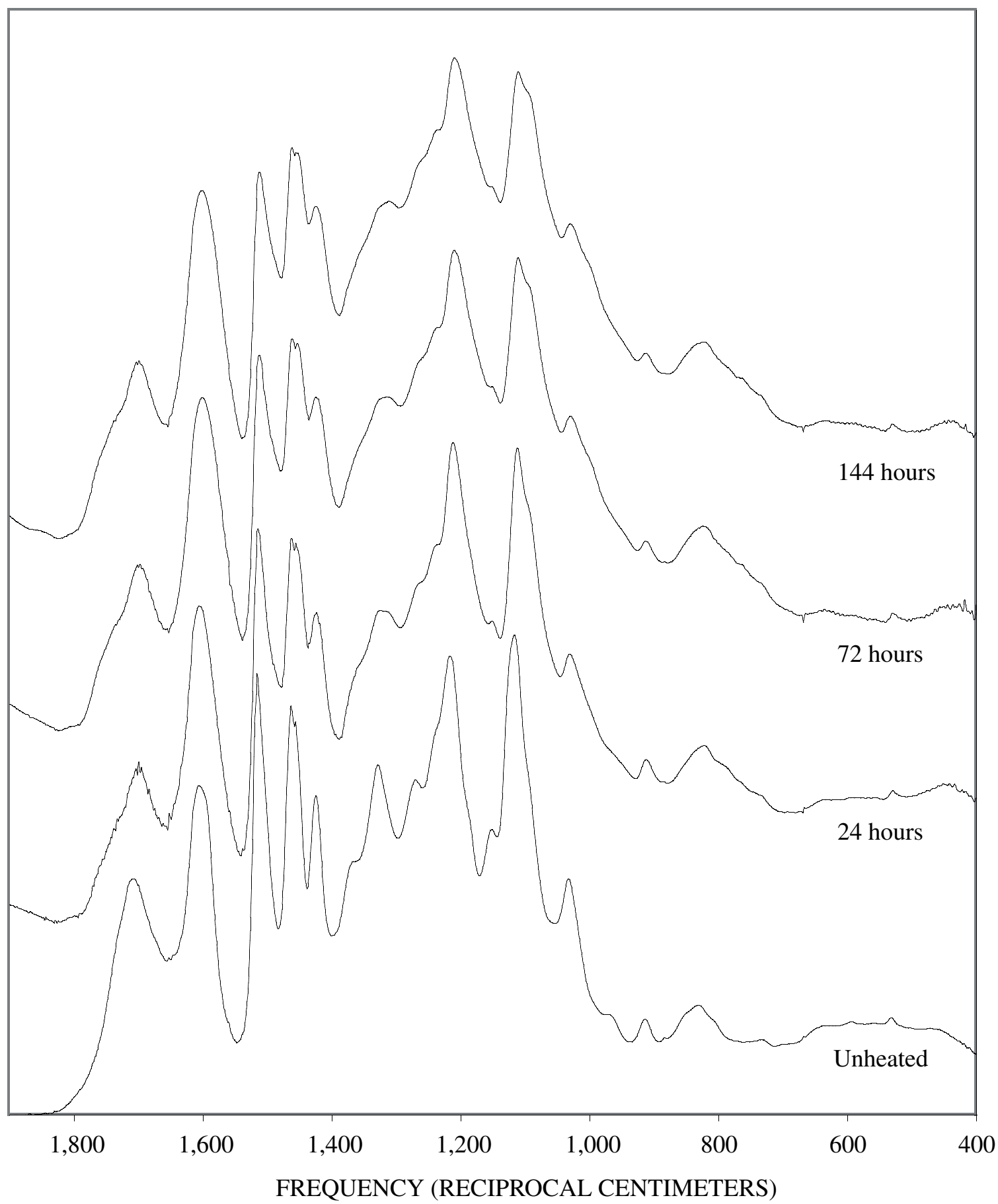

Figure B-6. Fourier Transform Infrared (FTIR) spectra of lignin heated at $250^{\circ} \mathrm{C}$ for various times. 


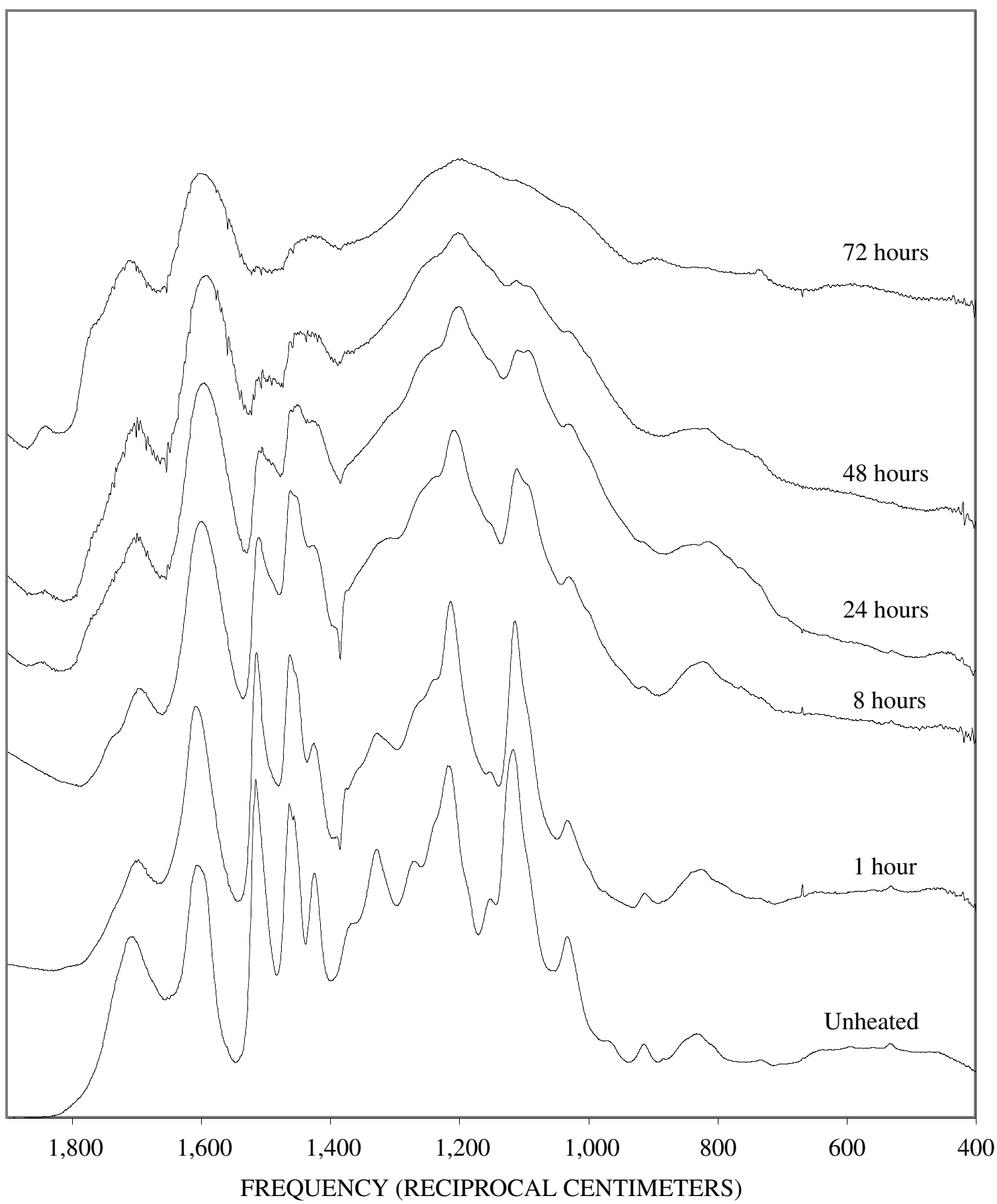

Figure B-7. Fourier Transform Infrared (FTIR) spectra of lignin heated at $300^{\circ} \mathrm{C}$ for various times. 


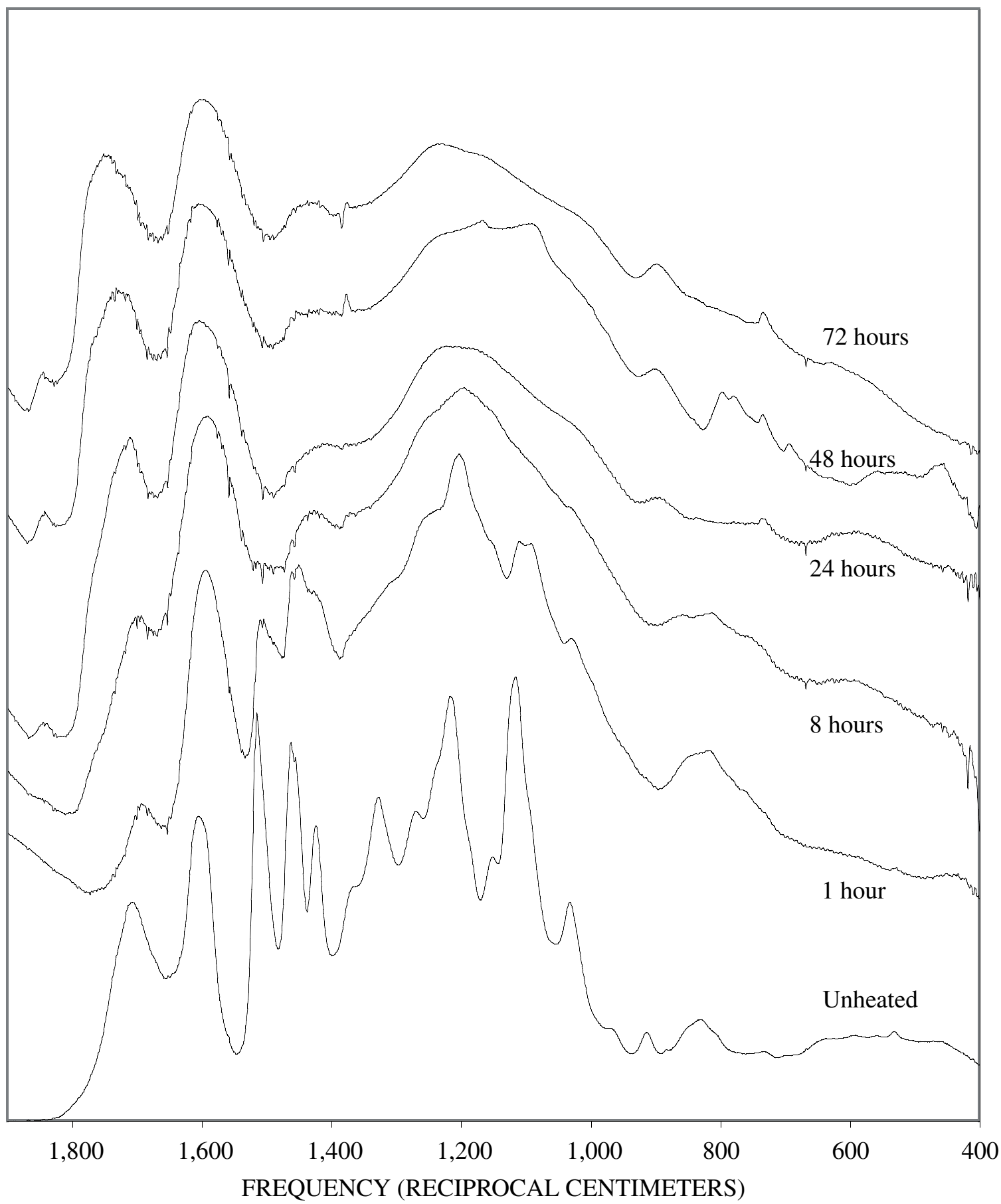

Figure B-8. Fourier Transform Infrared (FTIR) spectra of lignin heated at $350^{\circ} \mathrm{C}$ for various times. 


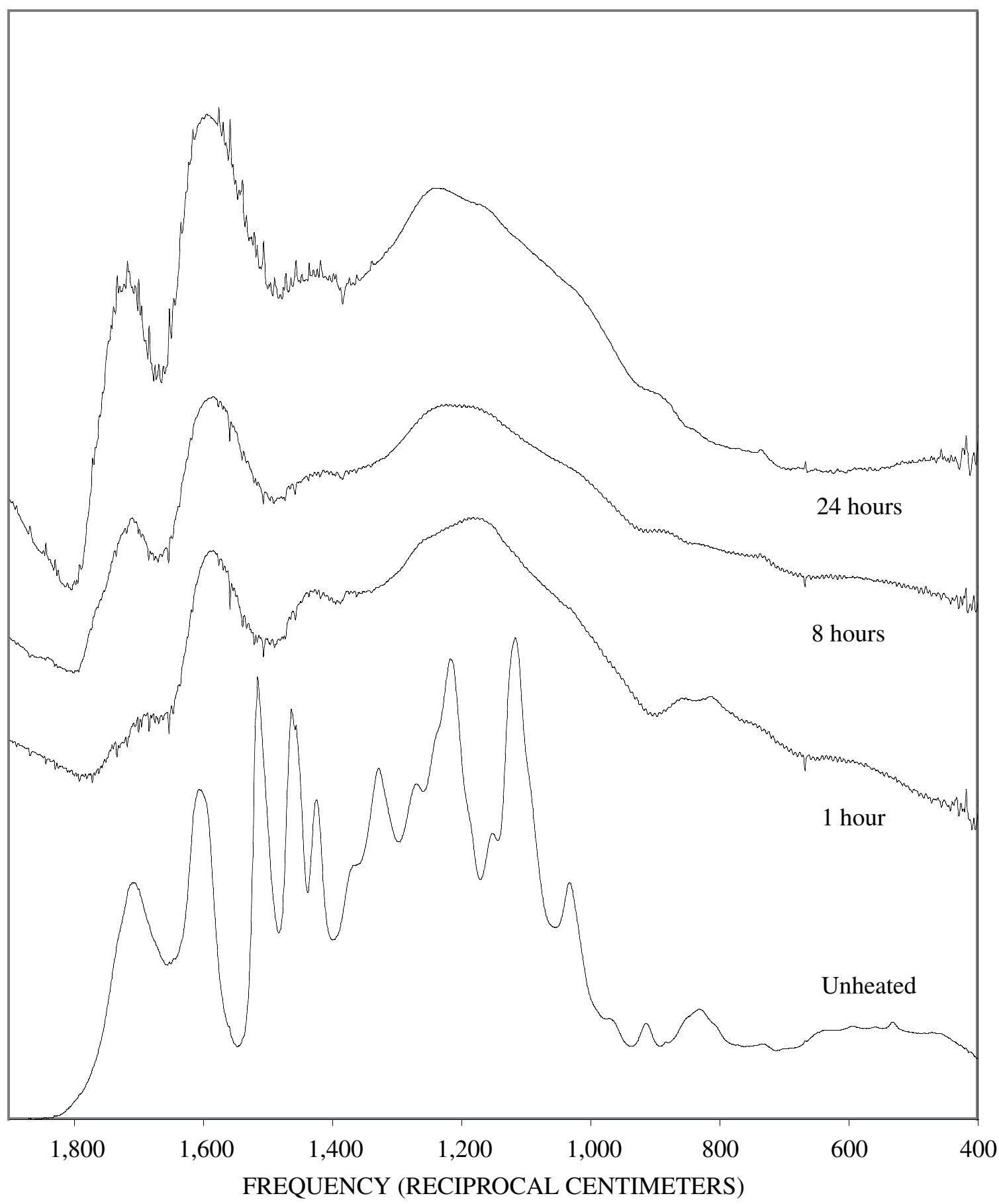

Figure B-9. Fourier Transform Infrared (FTIR) spectra of lignin heated at $400^{\circ} \mathrm{C}$ for various times. 


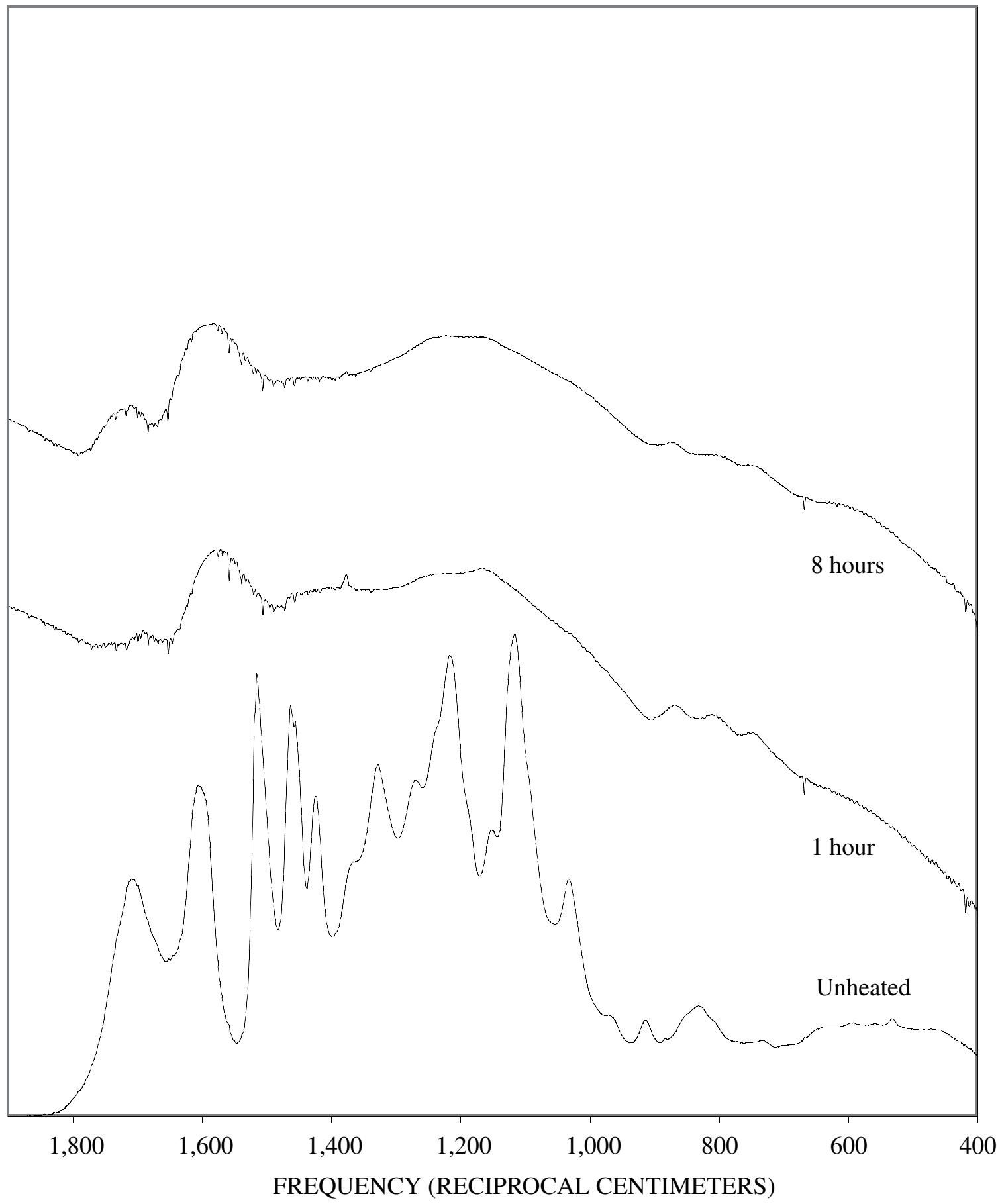

Figure B-10. Fourier Transform Infrared (FTIR) spectra of lignin heated at $500^{\circ} \mathrm{C}$ for various times. 


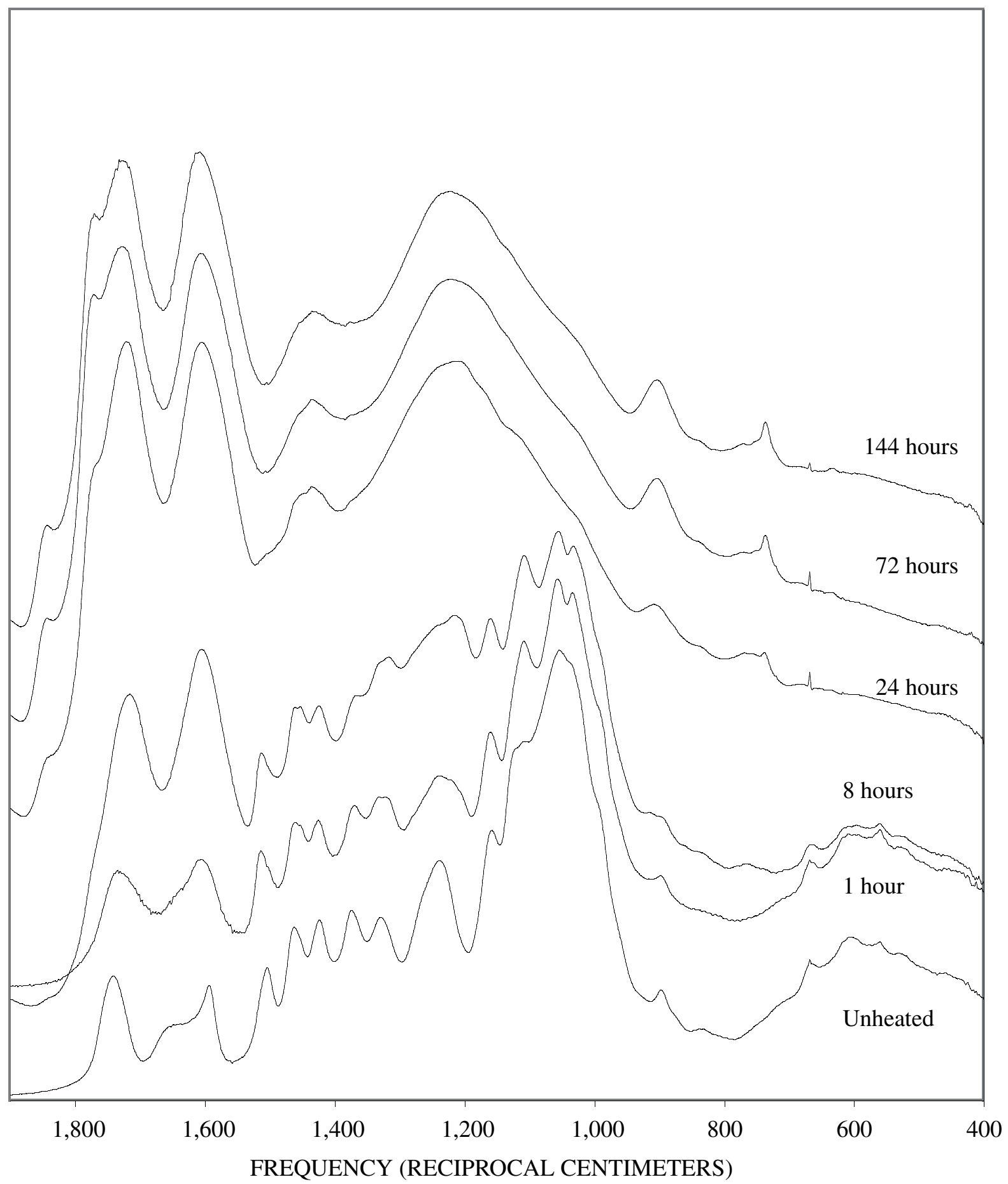

Figure B-11. Fourier Transform Infrared (FTIR) spectra of poplar wood heated at $250^{\circ} \mathrm{C}$ for various times. 


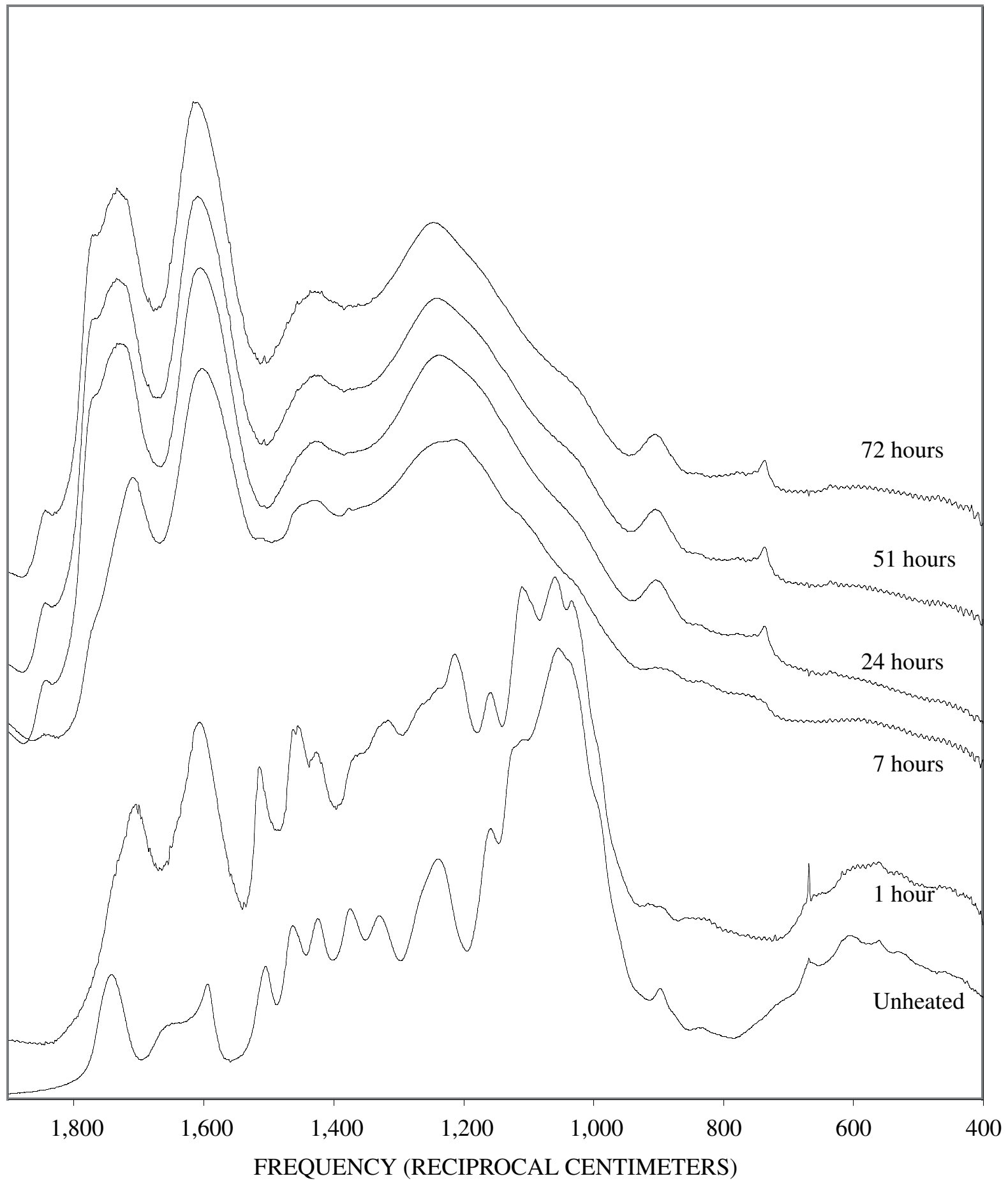

Figure B-12. Fourier Transform Infrared (FTIR) spectra of poplar wood heated at $300^{\circ} \mathrm{C}$ for various times. 


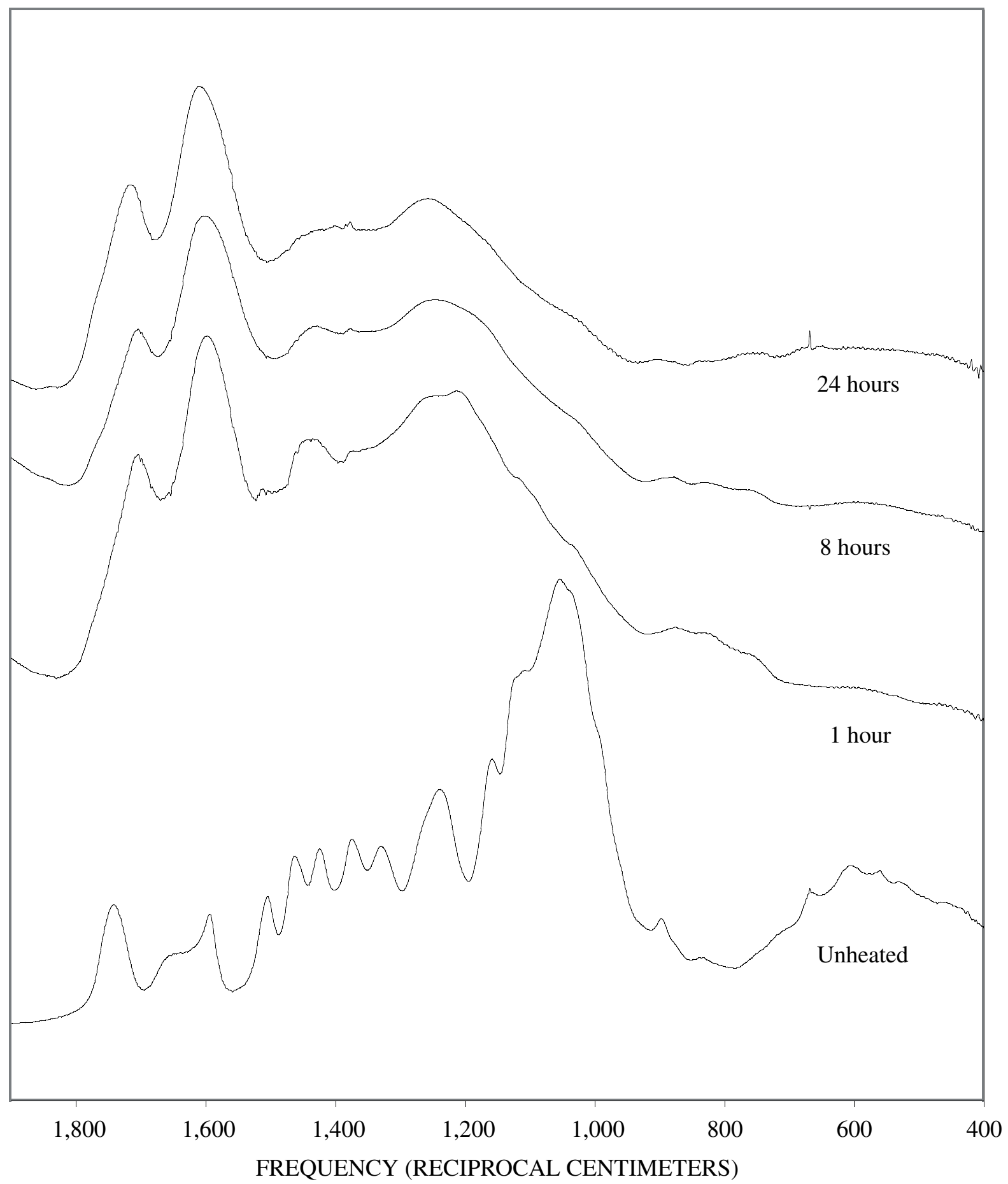

Figure B-13. Fourier Transform Infrared (FTIR) spectra of poplar wood heated at $350^{\circ} \mathrm{C}$ for various times. 


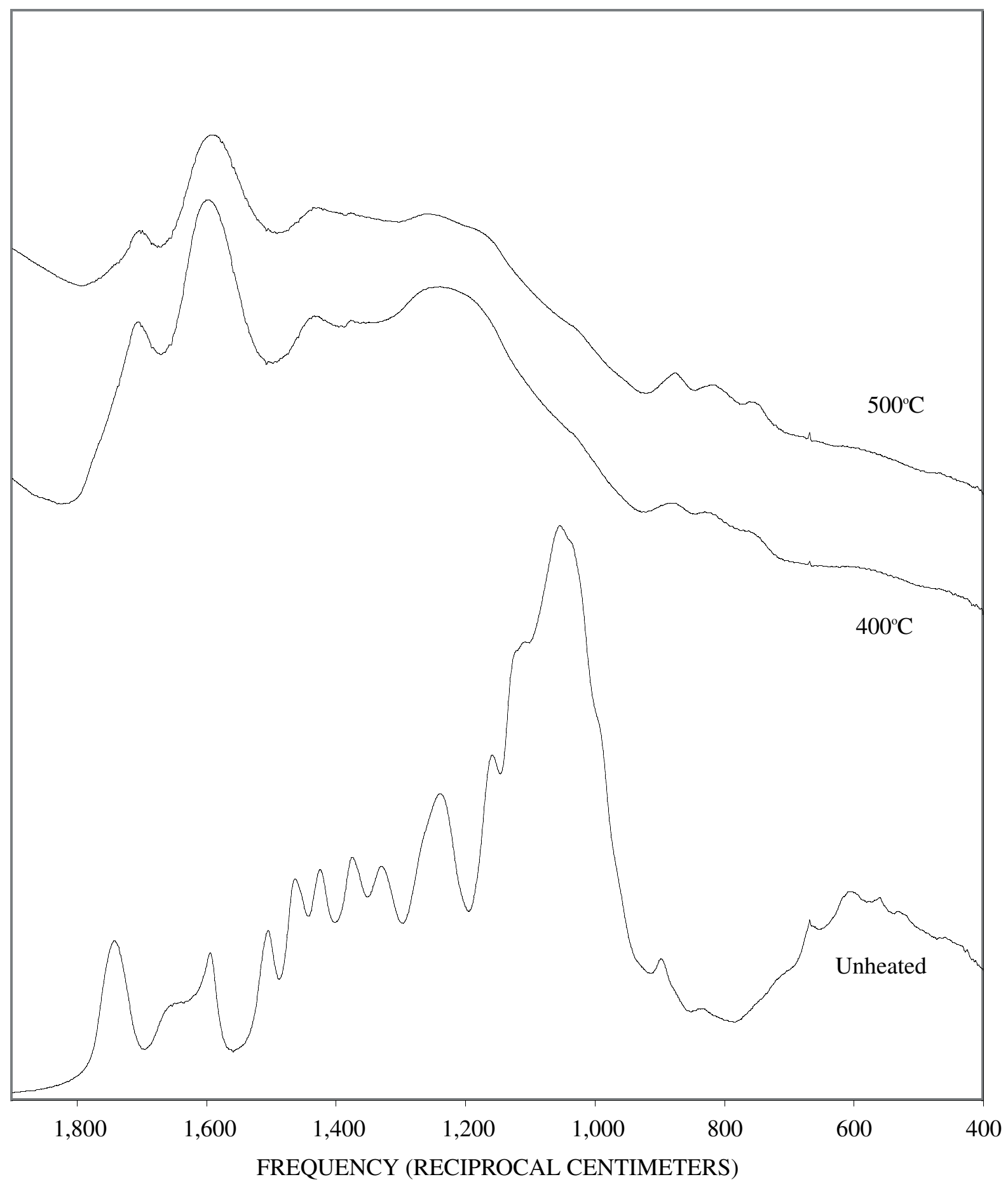

Figure B-14. Fourier Transform Infrared (FTIR) spectra of poplar wood heated at $400^{\circ} \mathrm{C}$ and $500^{\circ} \mathrm{C}$ for one hour. 


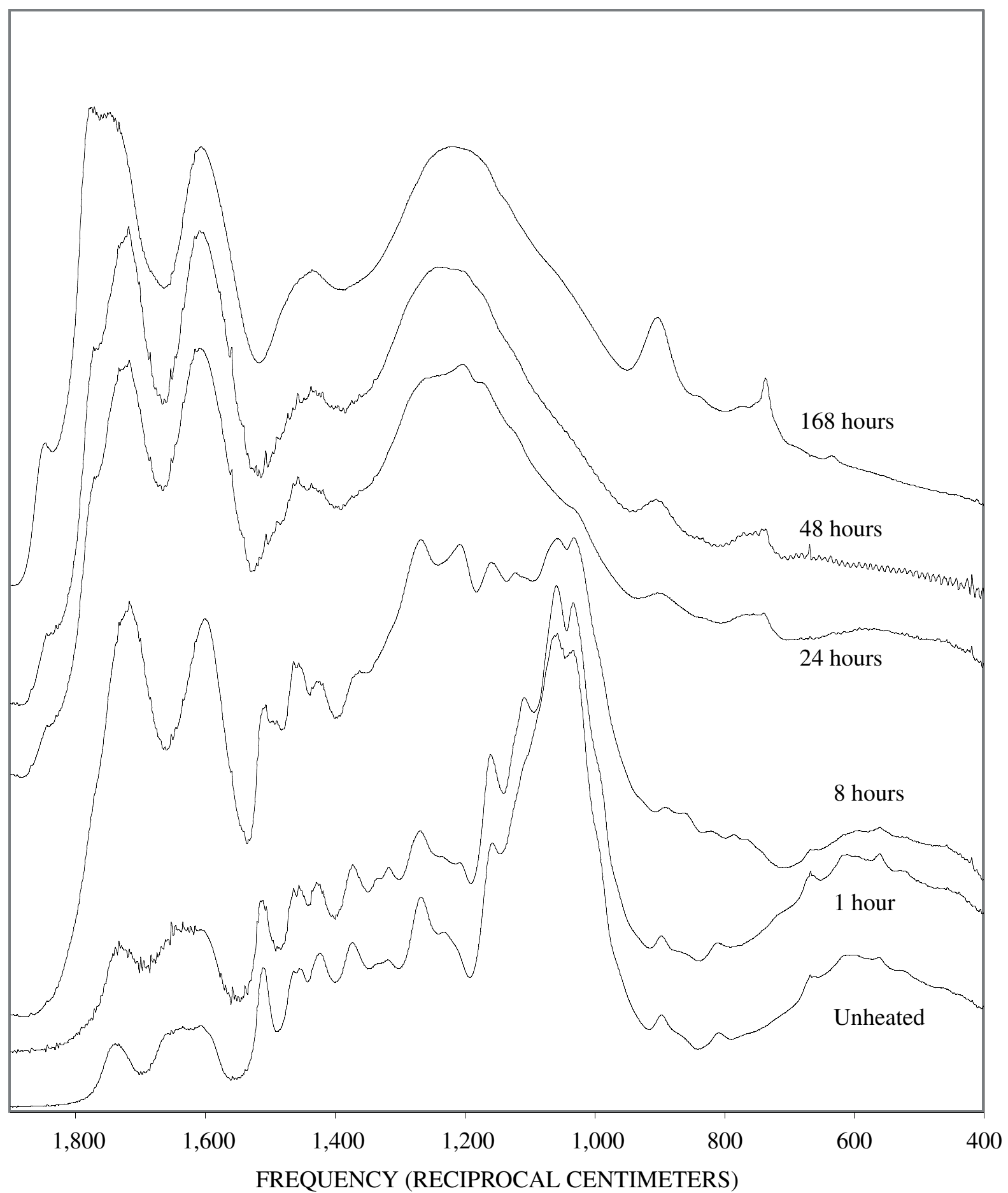

Figure B-15. Fourier Transform Infrared (FTIR) spectra of pine wood heated at $250^{\circ} \mathrm{C}$ for various times. 


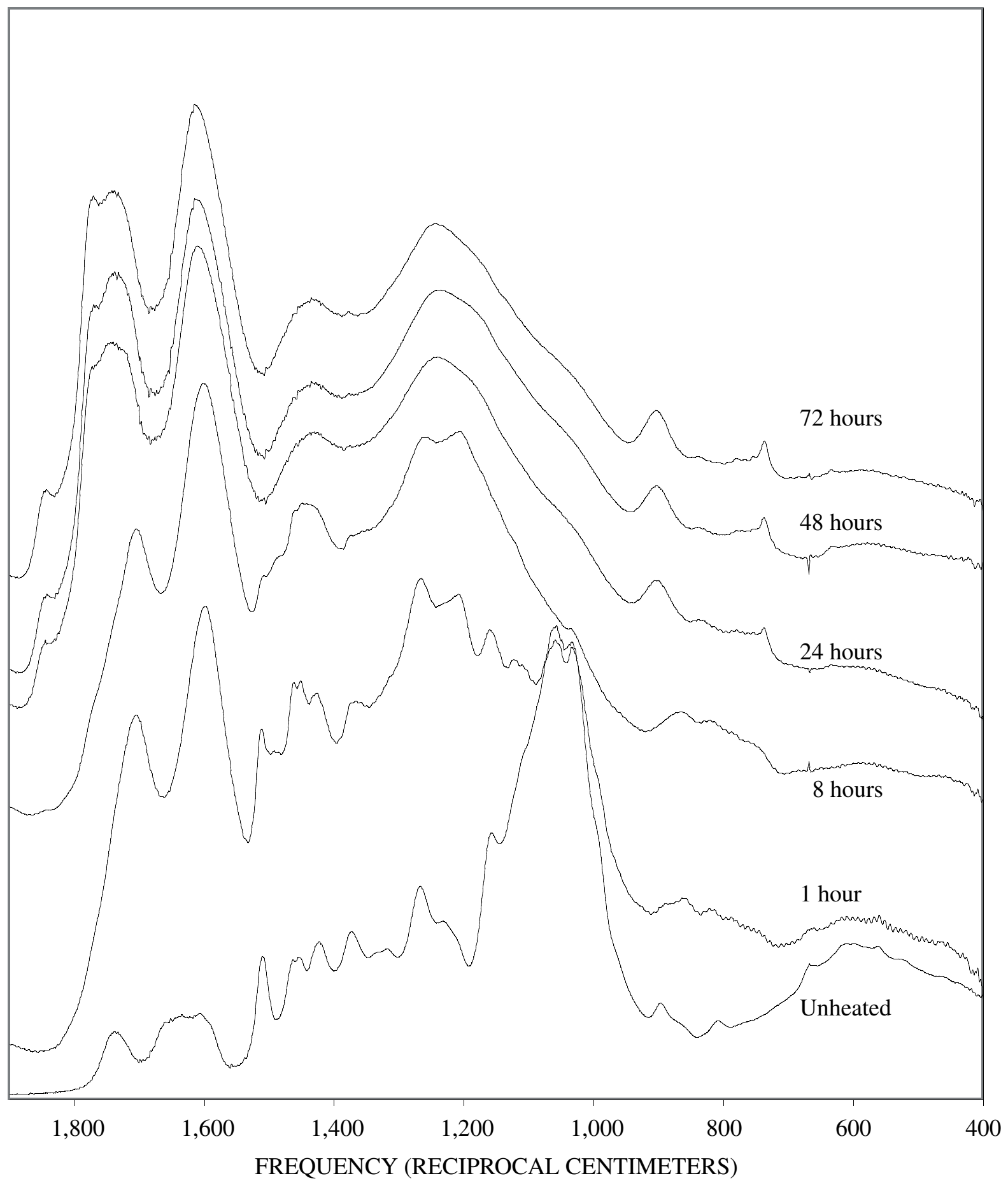

Figure B-16. Fourier Transform Infrared (FTIR) spectra of pine wood heated at $300^{\circ} \mathrm{C}$ for various times. 


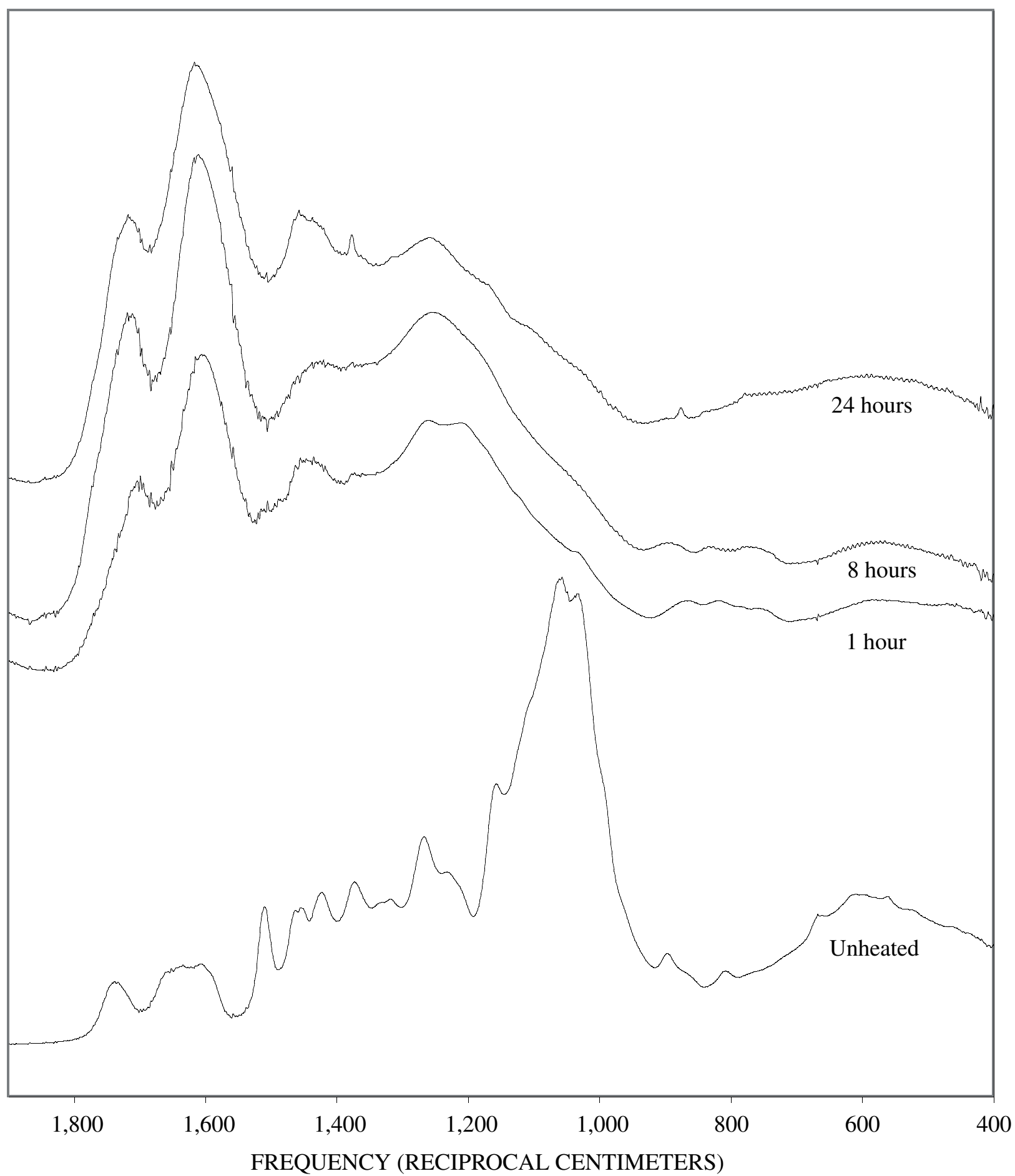

Figure B-17. Fourier Transform Infrared (FTIR) spectra of pine wood heated at $350^{\circ} \mathrm{C}$ for various times. 


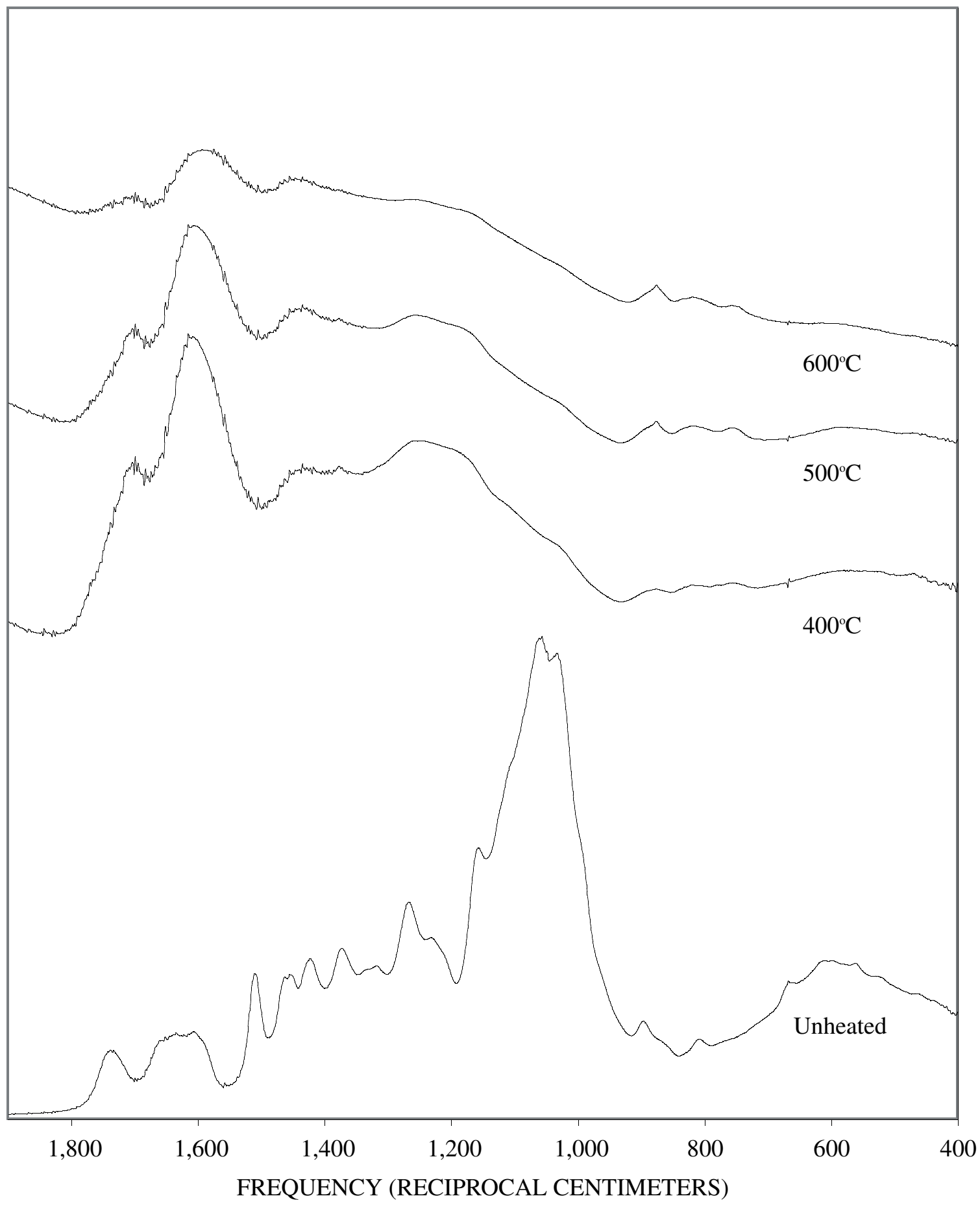

Figure B-18. Fourier Transform Infrared (FTIR) spectra of pine wood heated at $400^{\circ} \mathrm{C}, 500^{\circ} \mathrm{C}$, and $600^{\circ} \mathrm{C}$ for one hour. 


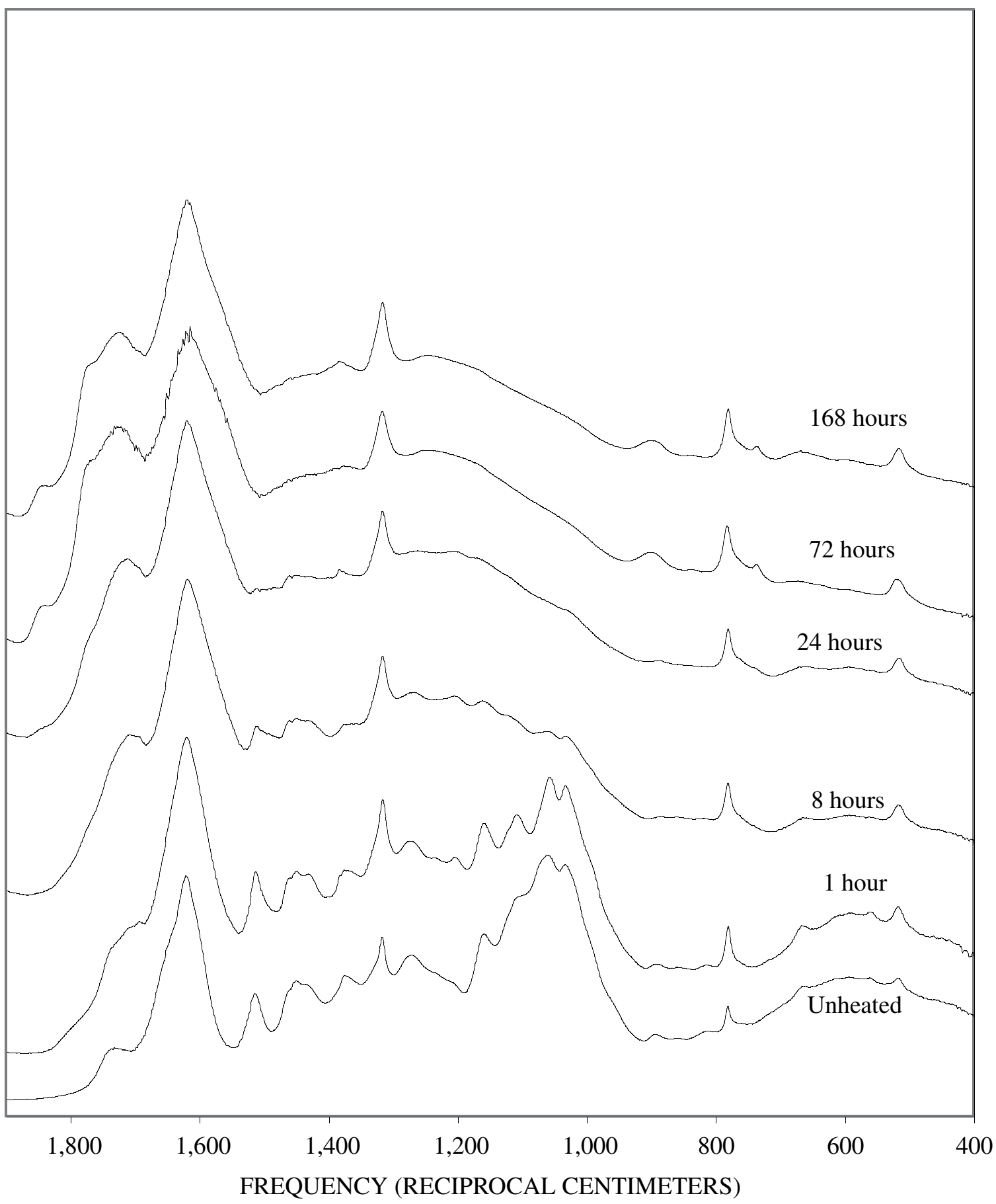

Figure B-19. Fourier Transform Infrared (FTIR) spectra of pine bark heated at $250^{\circ} \mathrm{C}$ for various times. 


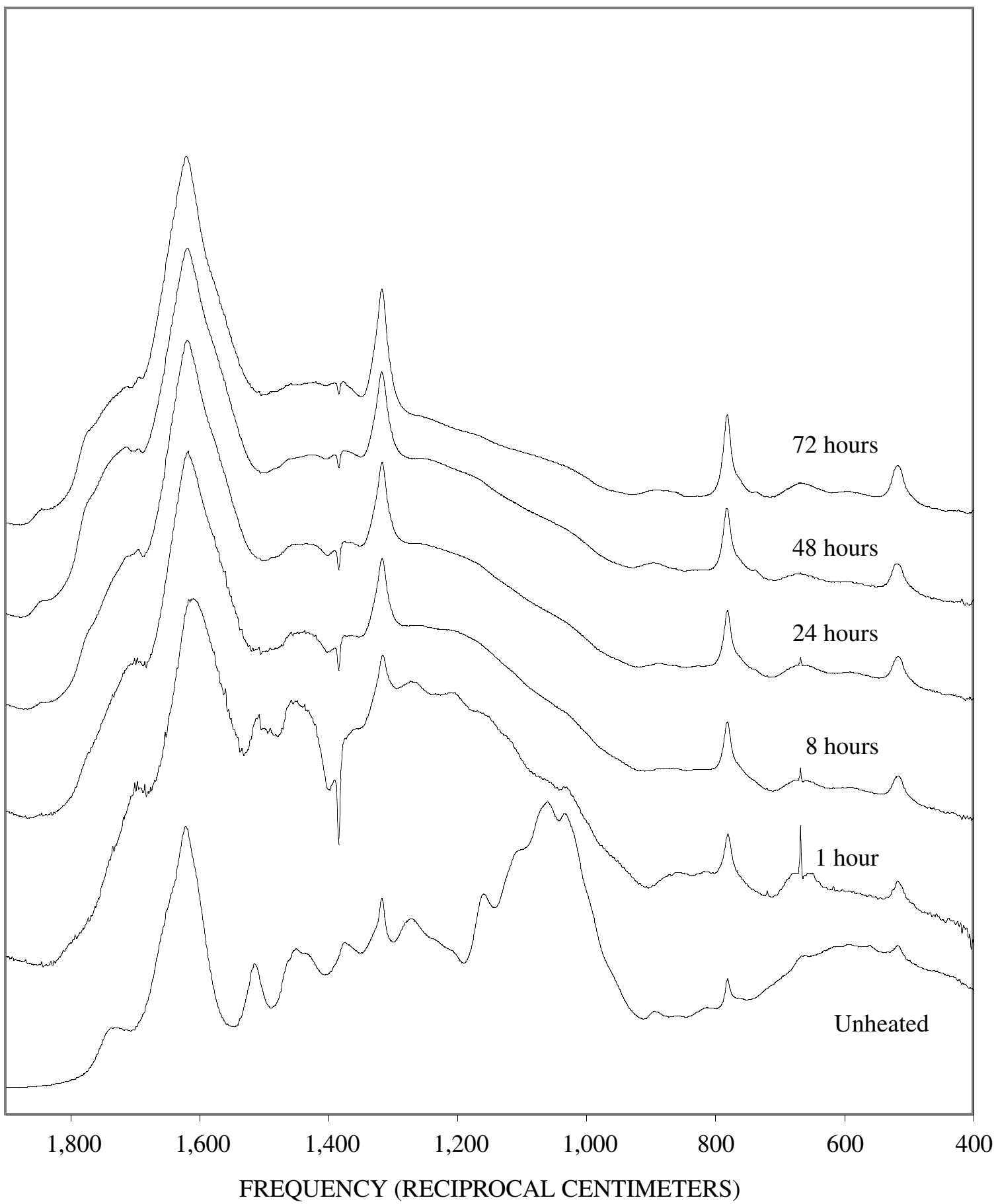

Figure B-20. Fourier Transform Infrared (FTIR) spectra of pine bark heated at $300^{\circ} \mathrm{C}$ for various times. 


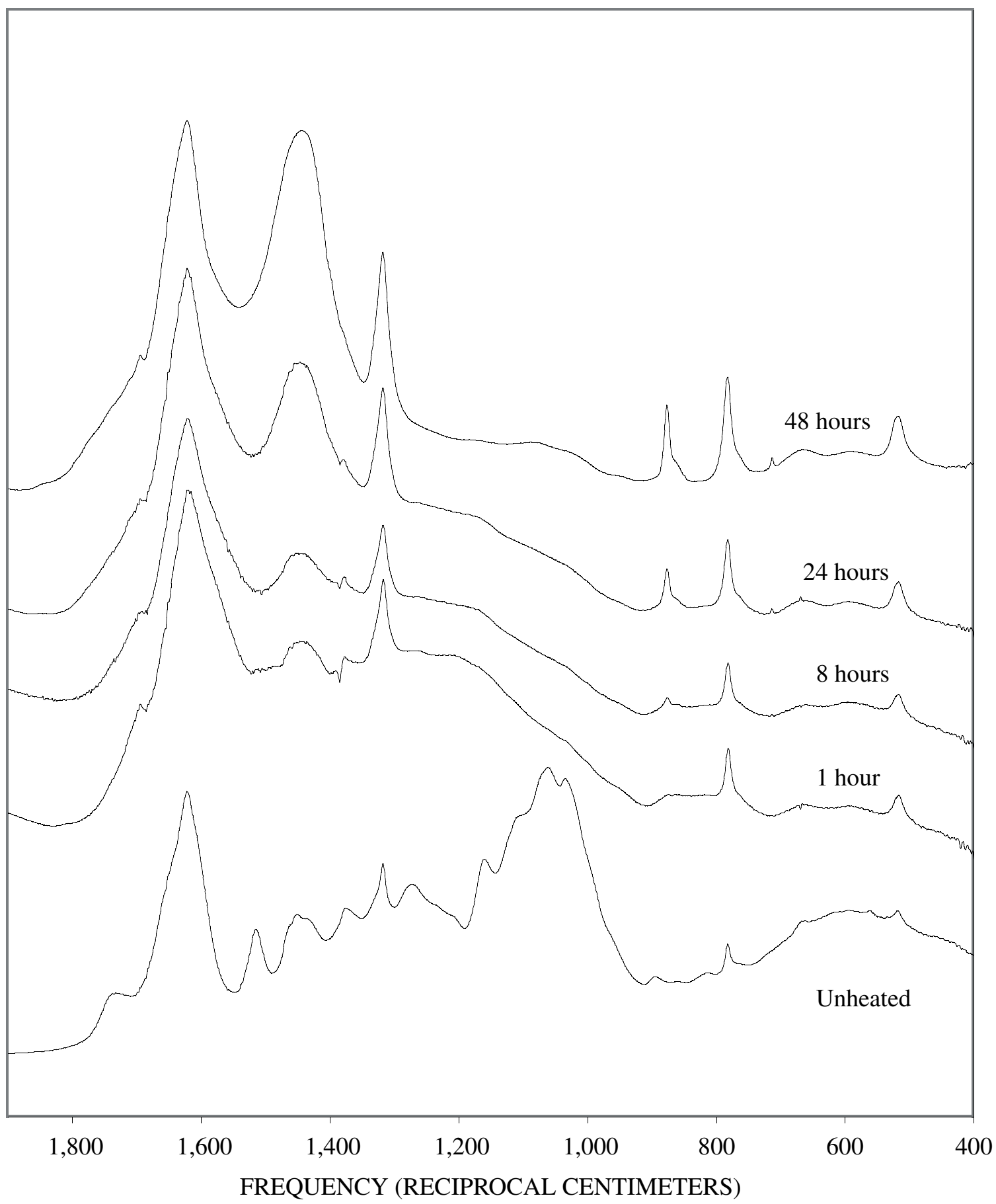

Figure B-21. Fourier Transform Infrared (FTIR) spectra of pine bark heated at $350^{\circ} \mathrm{C}$ for various times. 


\section{Appendix C. ${ }^{13} \mathrm{C}$ Nuclear Magnetic Resonance (NMR) Spectra}

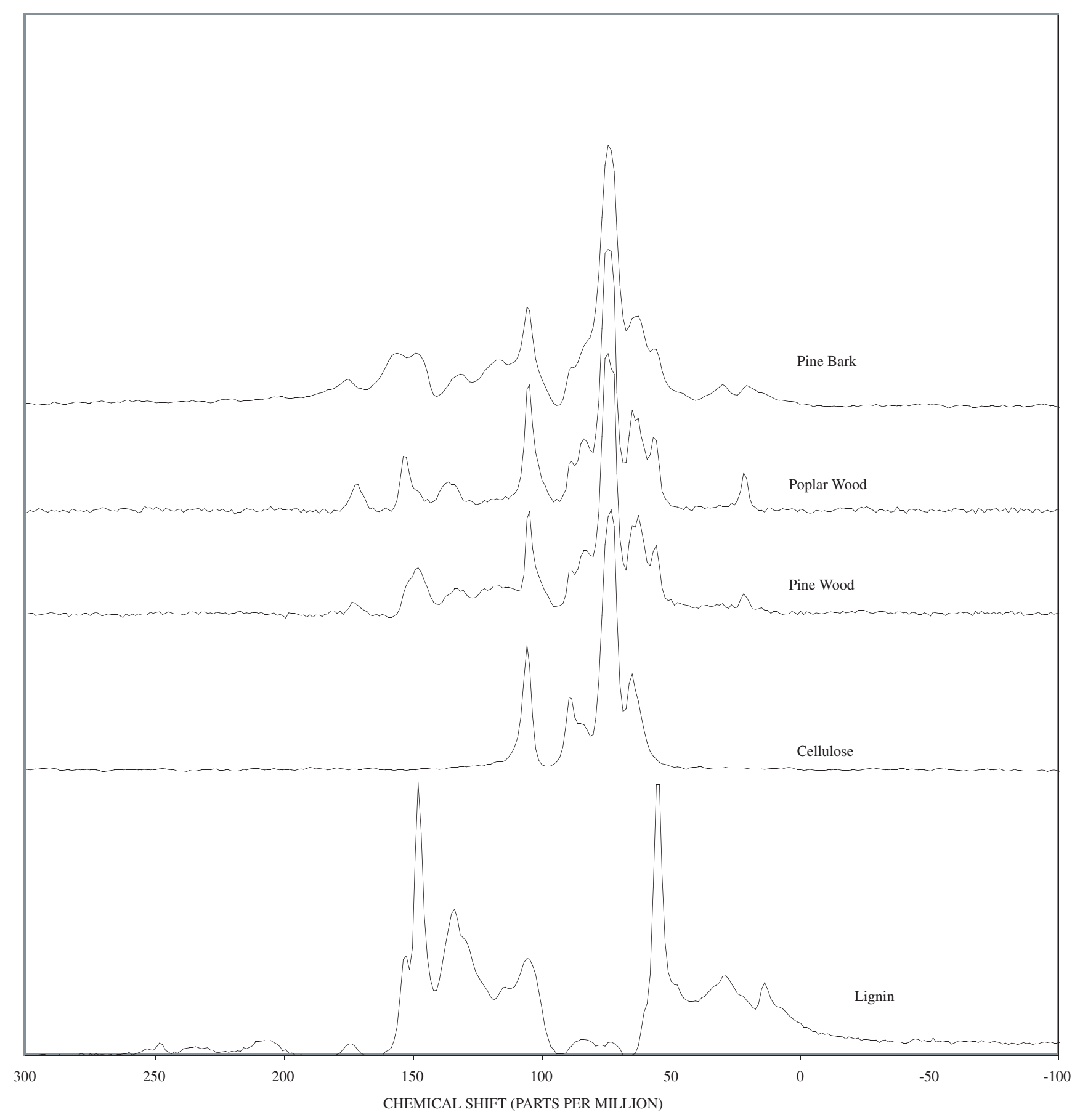

Figure C-1. ${ }^{13} \mathrm{C}$ Nuclear Magnetic Resonance (NMR) spectra of unheated cellulose, lignin, pine wood, poplar wood and pine bark. 


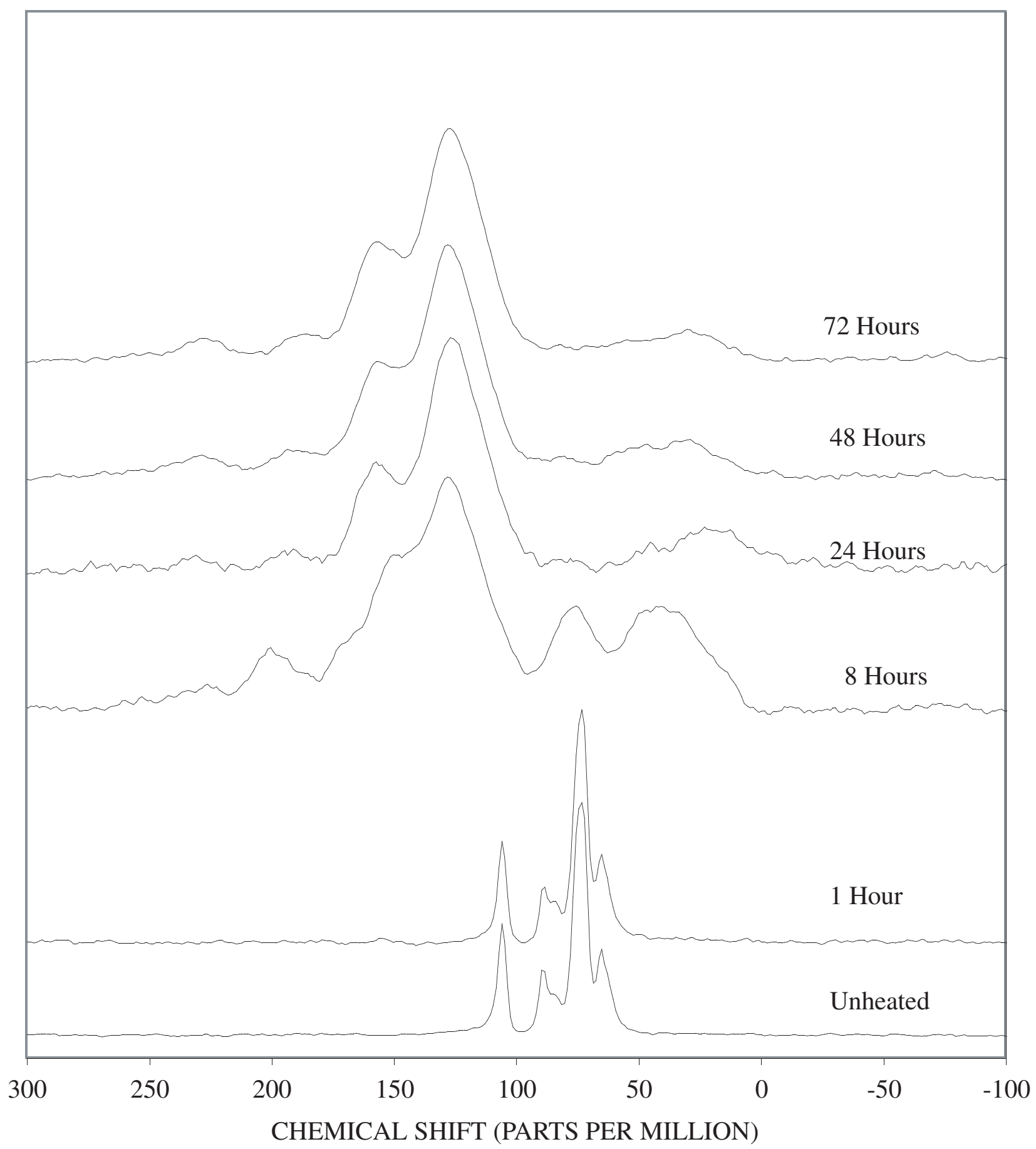

Figure C-2. $\quad{ }^{13} \mathrm{C}$ Nuclear Magnetic Resonance (NMR) spectra of cellulose heated at $250^{\circ} \mathrm{C}$ for various times. 


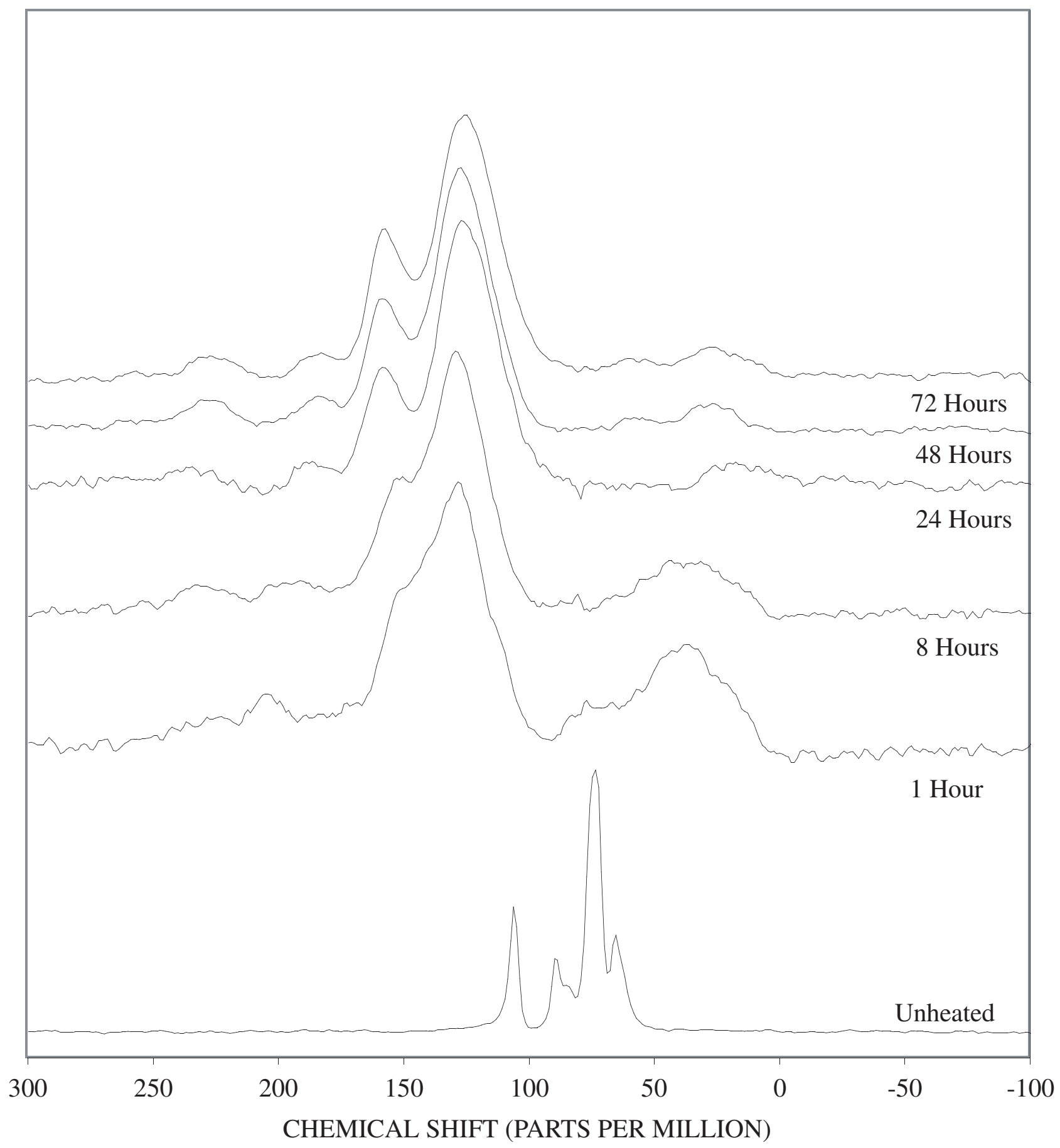

Figure C-3. ${ }^{13} \mathrm{C}$ Nuclear Magnetic Resonance (NMR) spectra of cellulose heated at $300^{\circ} \mathrm{C}$ for various times. 


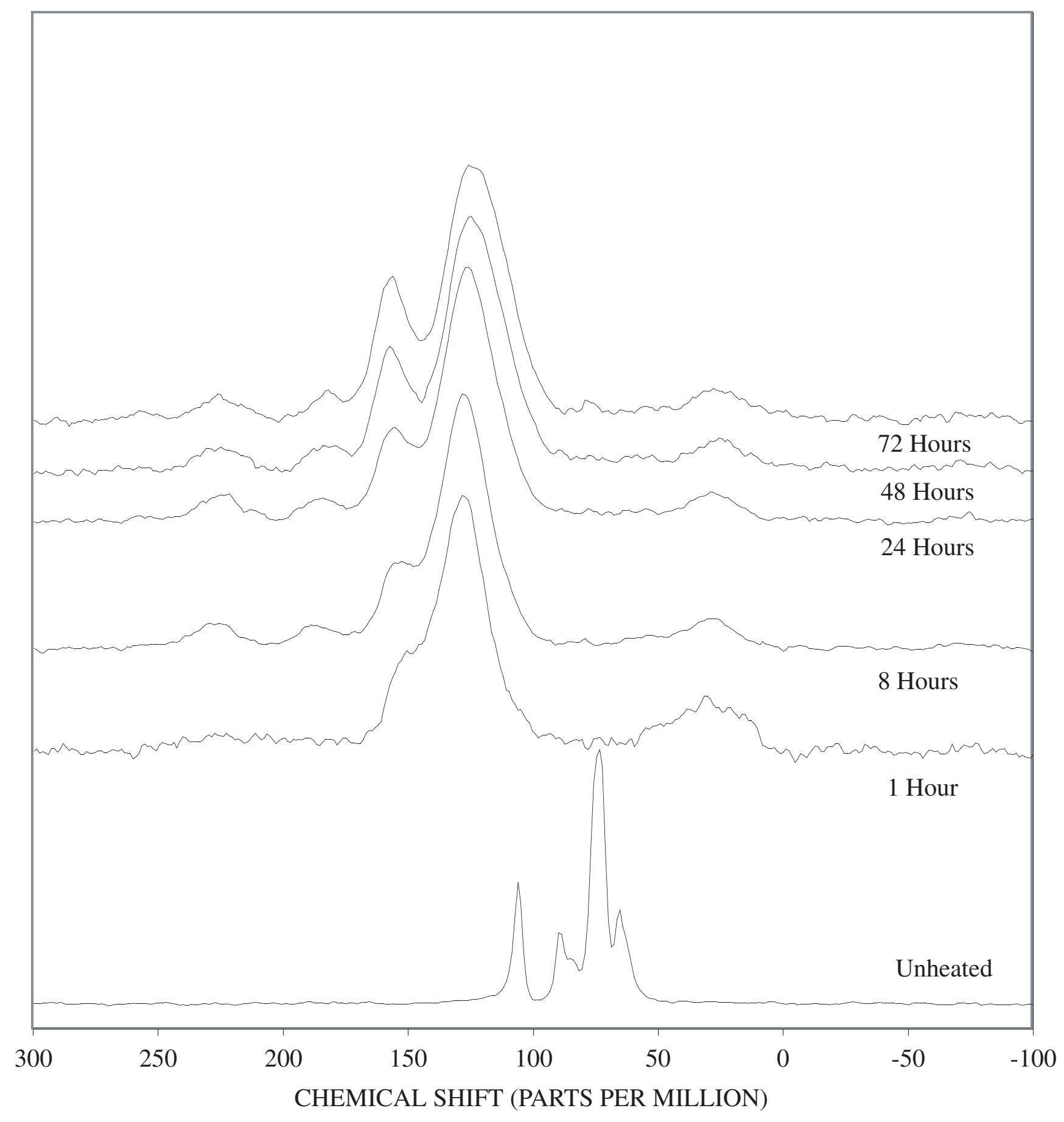

Figure C-4. ${ }^{13} \mathrm{C}$ Nuclear Magnetic Resonance (NMR) spectra of cellulose heated at $350^{\circ} \mathrm{C}$ for various times. 


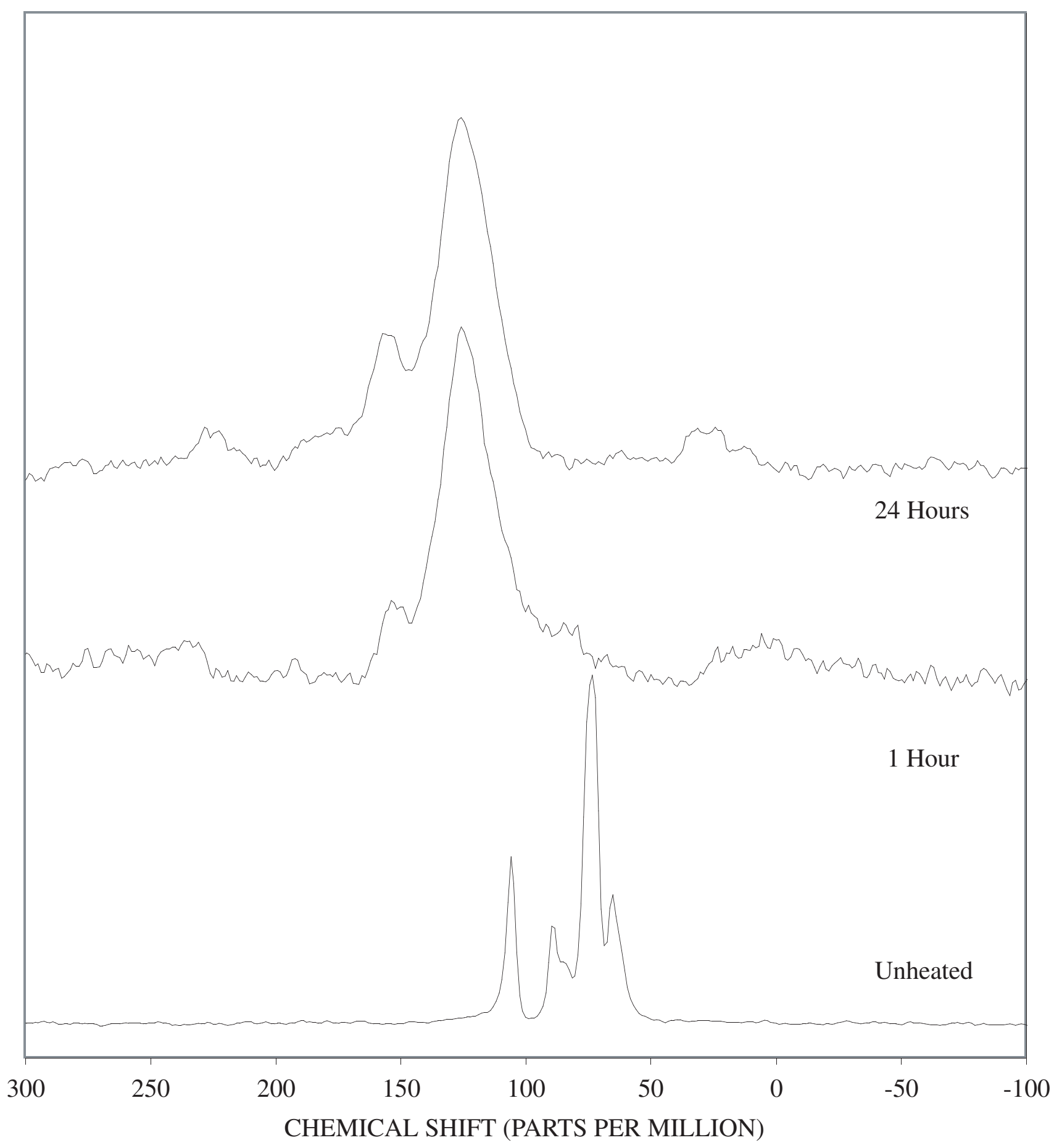

Figure C-5. ${ }^{13} \mathrm{C}$ Nuclear Magnetic Resonance (NMR) spectra of cellulose heated at $400^{\circ} \mathrm{C}$ for various times. 


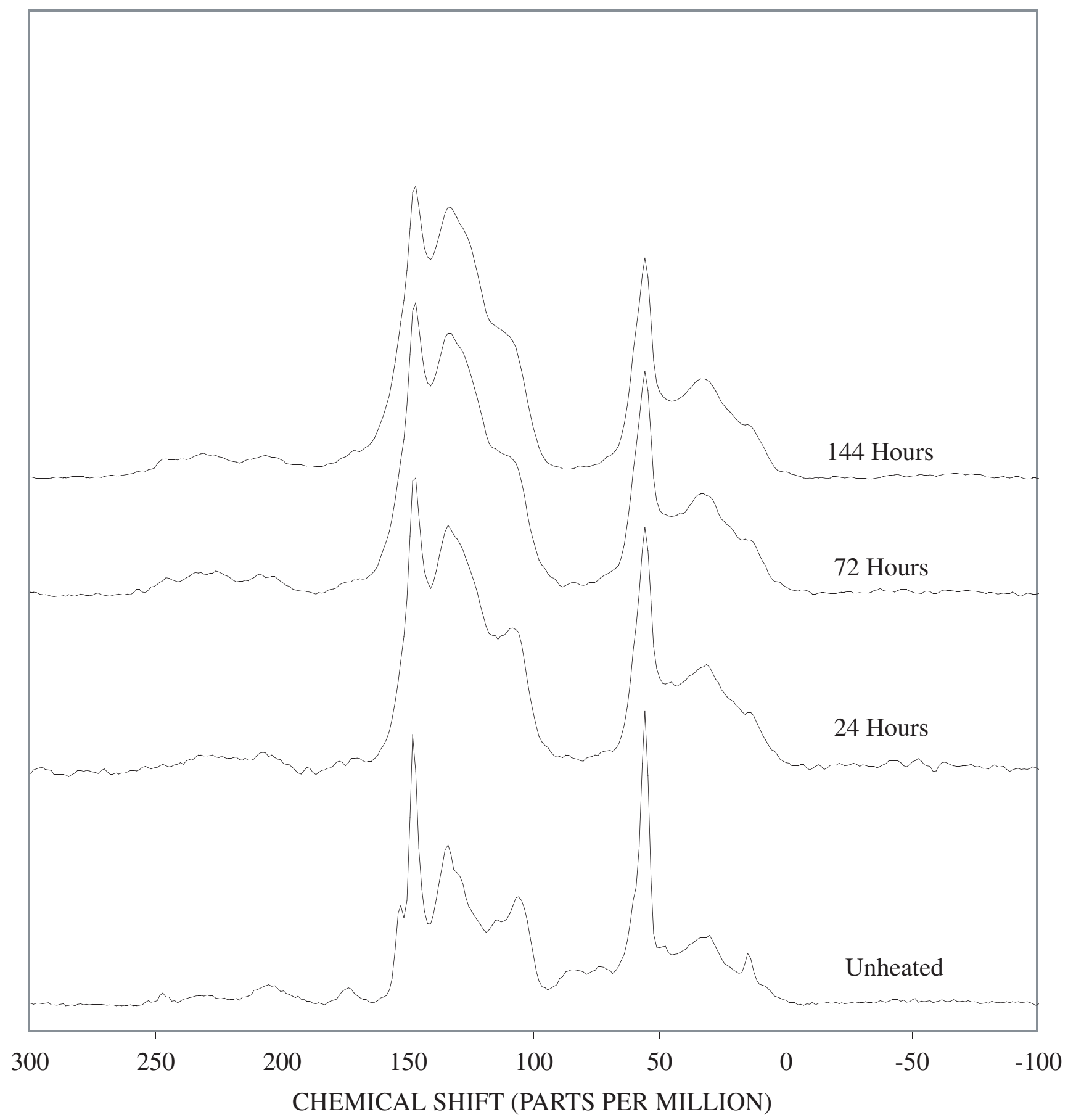

Figure C-6. $\quad{ }^{13} \mathrm{C}$ Nuclear Magnetic Resonance (NMR) spectra of lignin heated at $250^{\circ} \mathrm{C}$ for various times. 


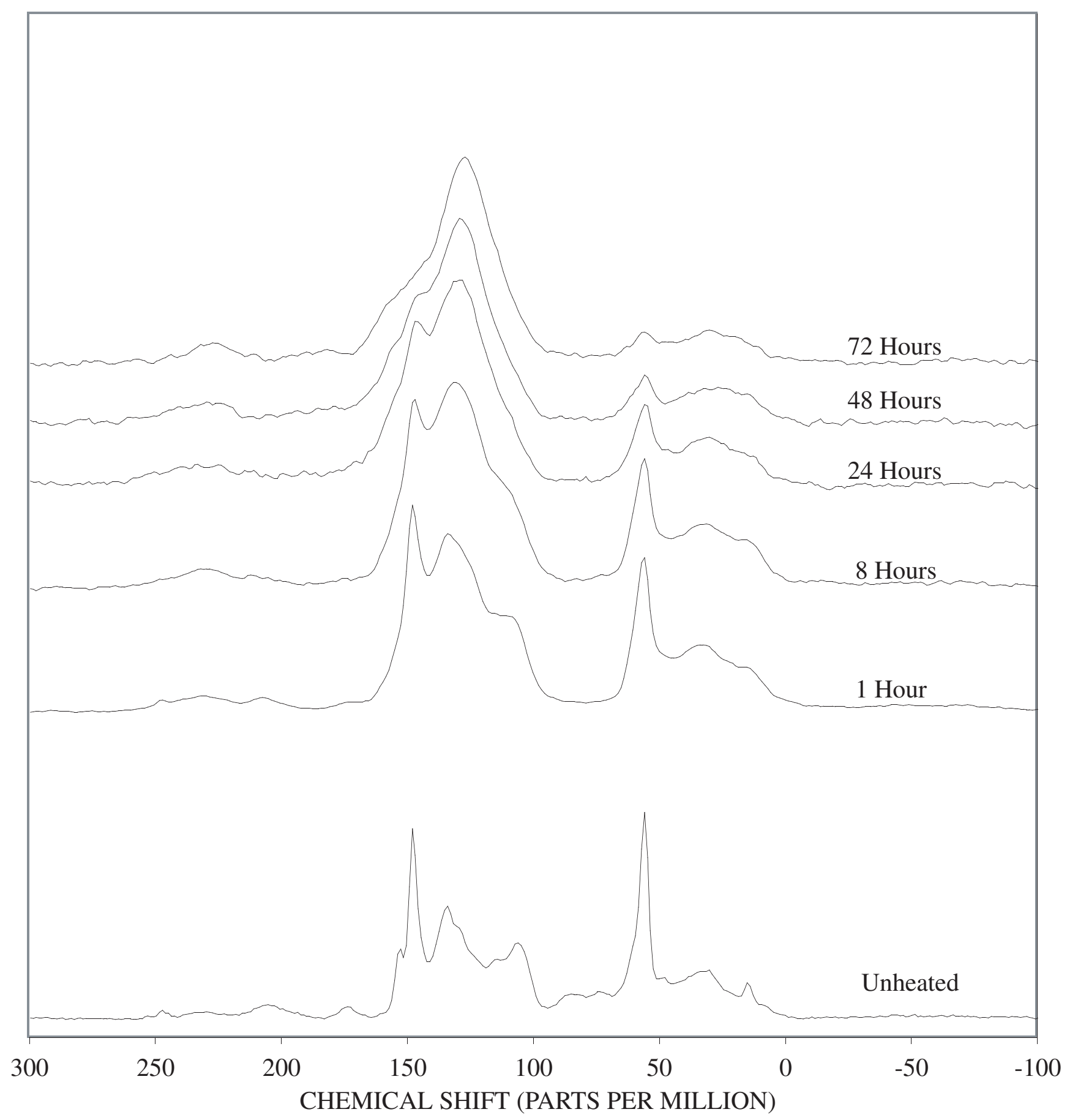

Figure C-7. ${ }^{13} \mathrm{C}$ Nuclear Magnetic Resonance (NMR) spectra of lignin heated at $300^{\circ} \mathrm{C}$ for various times. 


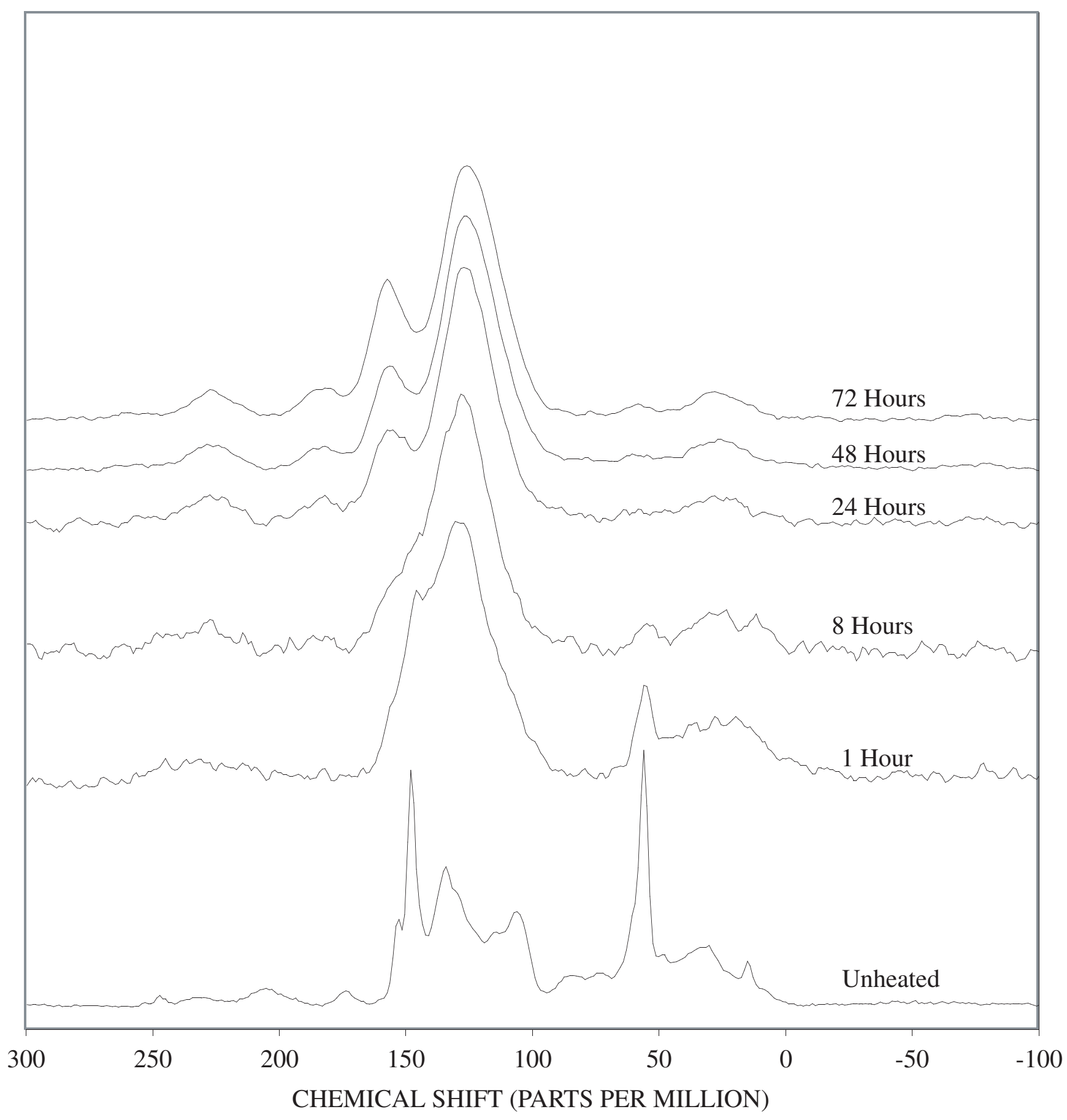

Figure C-8. ${ }^{13} \mathrm{C}$ Nuclear Magnetic Resonance (NMR) spectra of lignin heated at $350^{\circ} \mathrm{C}$ for various times. 


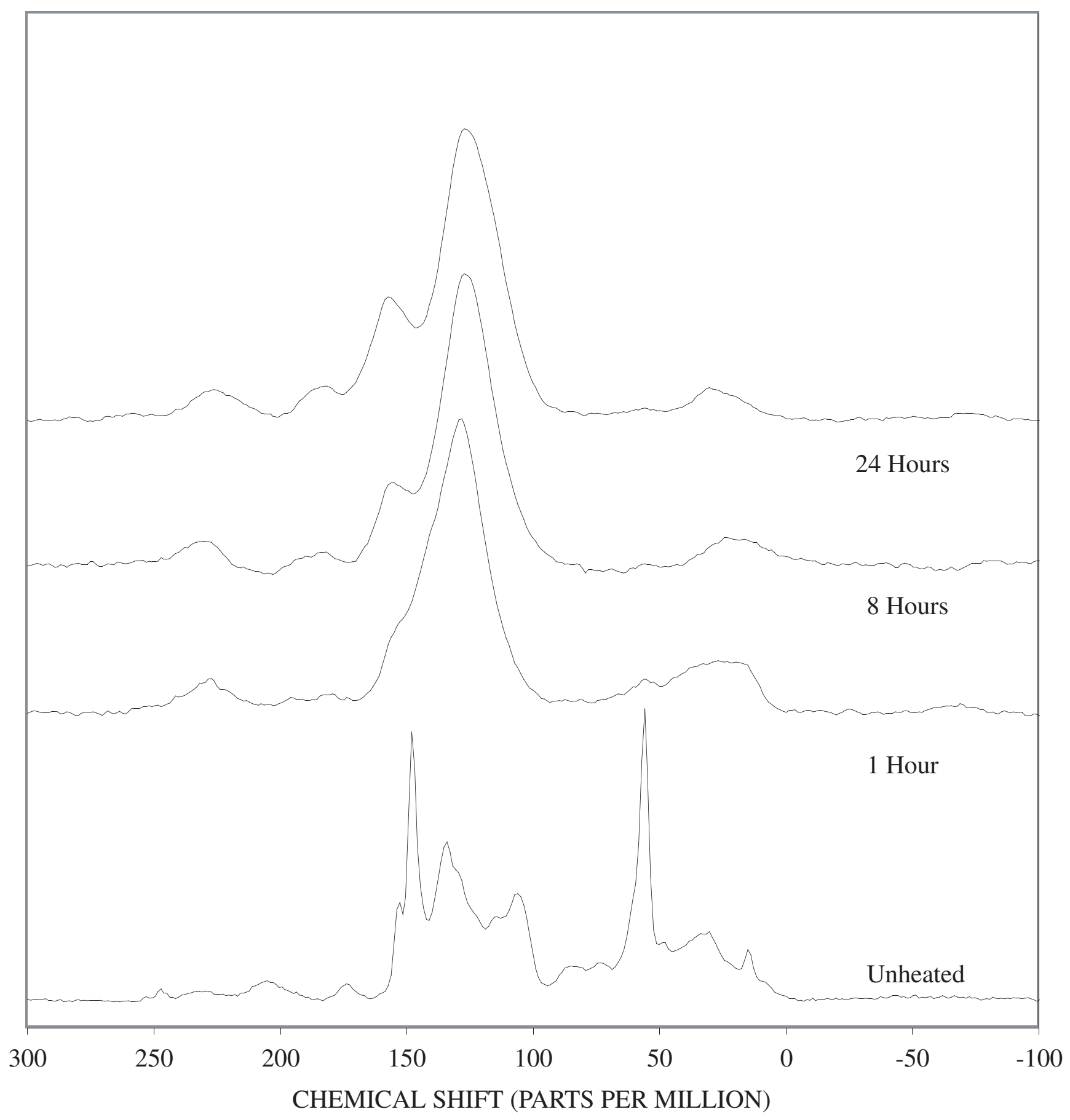

Figure C-9. ${ }^{13} \mathrm{C}$ Nuclear Magnetic Resonance (NMR) spectra of lignin heated at $400^{\circ} \mathrm{C}$ for various times. 


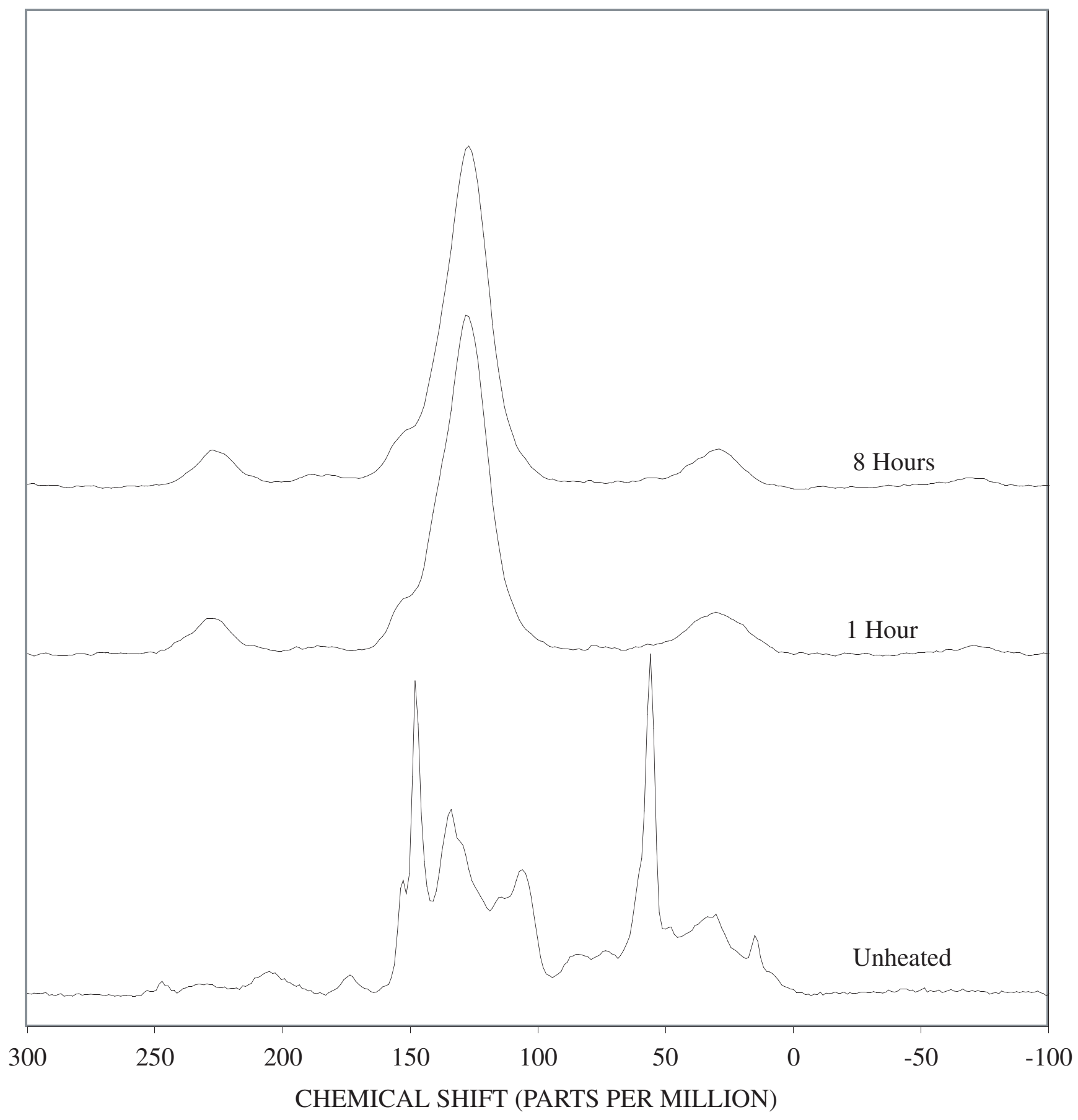

Figure C-10. $\quad{ }^{13} \mathrm{C}$ Nuclear Magnetic Resonance (NMR) spectra of lignin heated at $500^{\circ} \mathrm{C}$ for various times. 


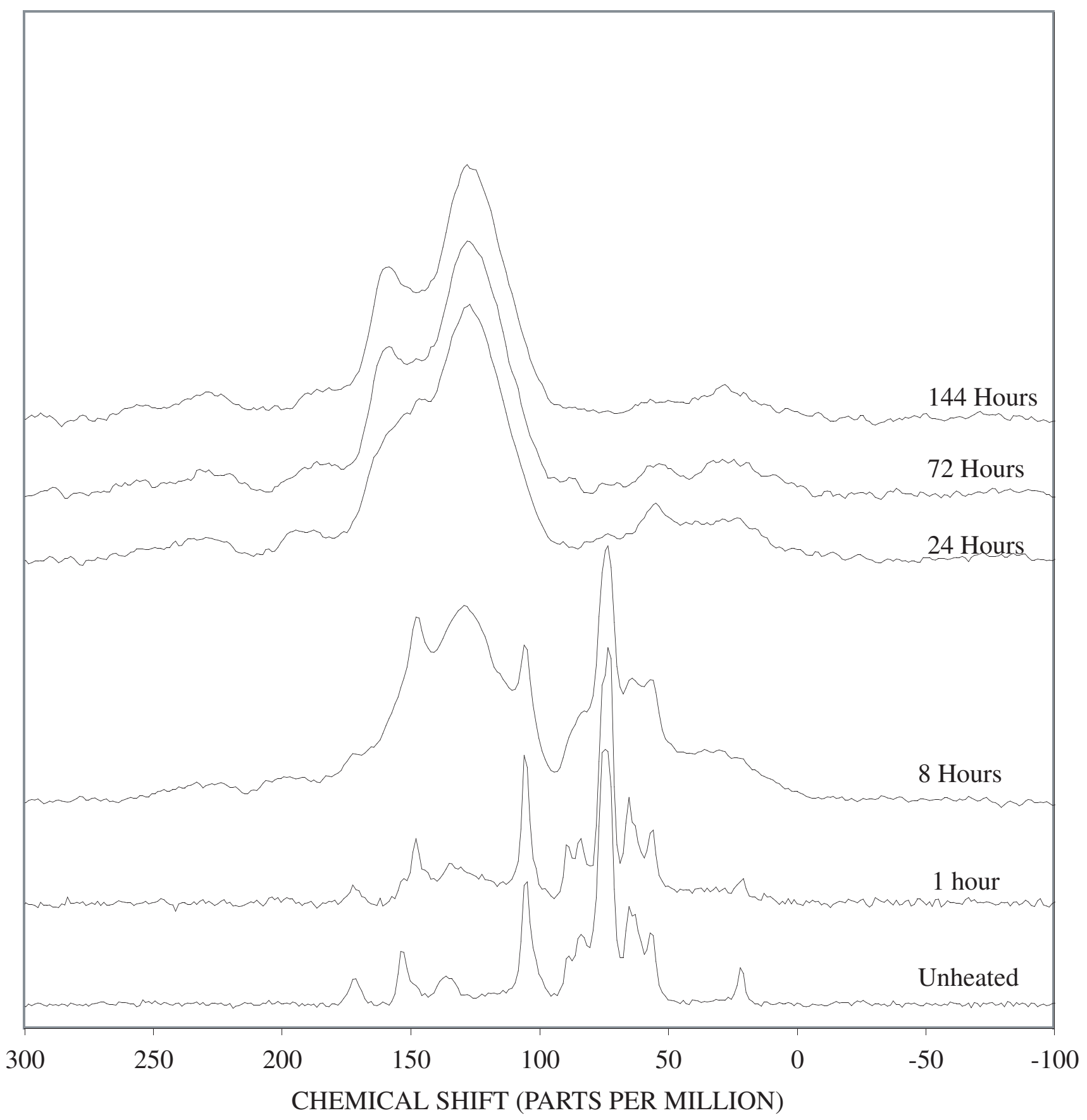

Figure C-11. ${ }^{13} \mathrm{C}$ Nuclear Magnetic Resonance (NMR) spectra of poplar wood heated at $250^{\circ} \mathrm{C}$ for various times. 


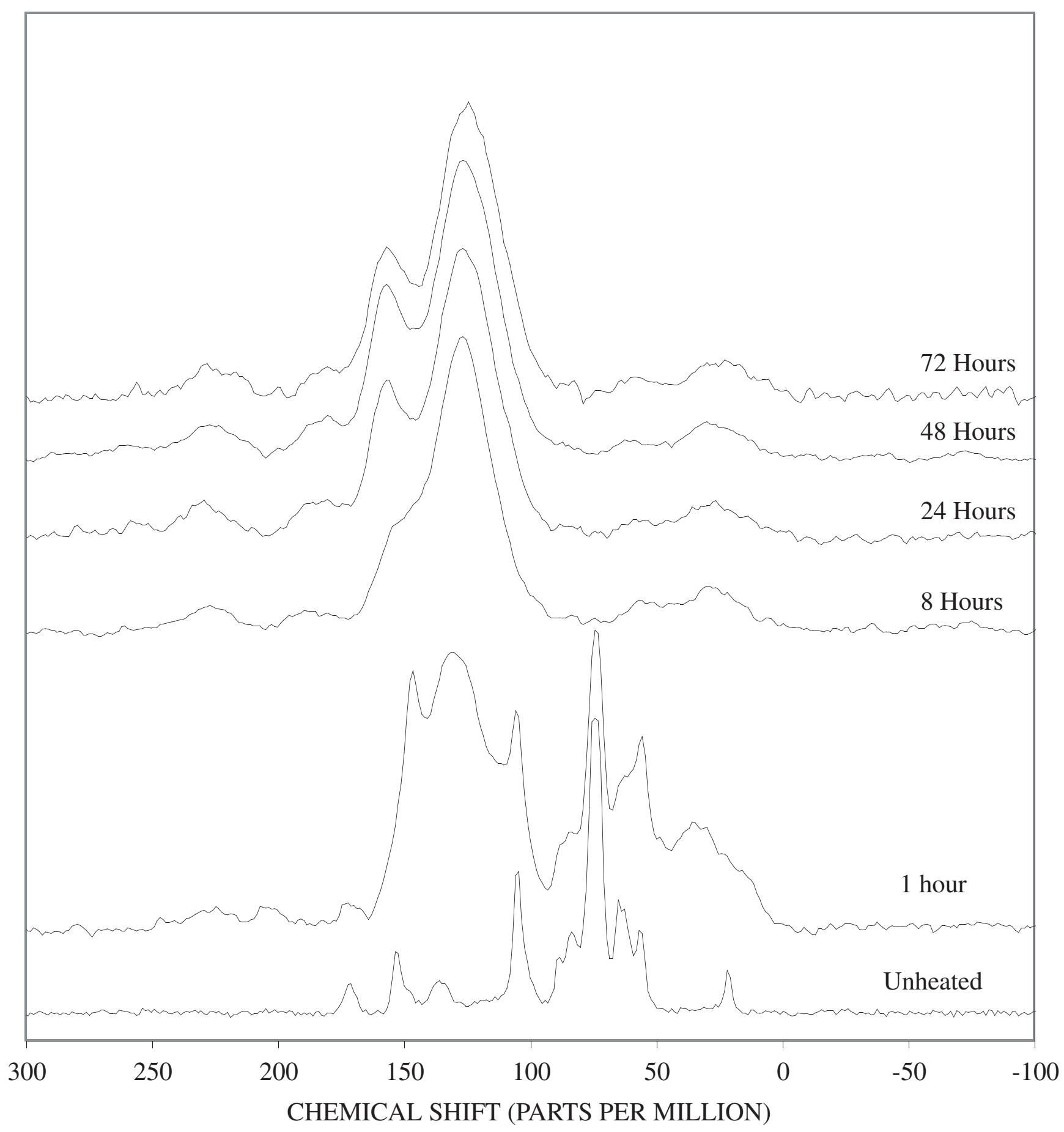

Figure C-12. ${ }^{13} \mathrm{C}$ Nuclear Magnetic Resonance (NMR)spectra of poplar wood heated at $300^{\circ} \mathrm{C}$ for various times. 


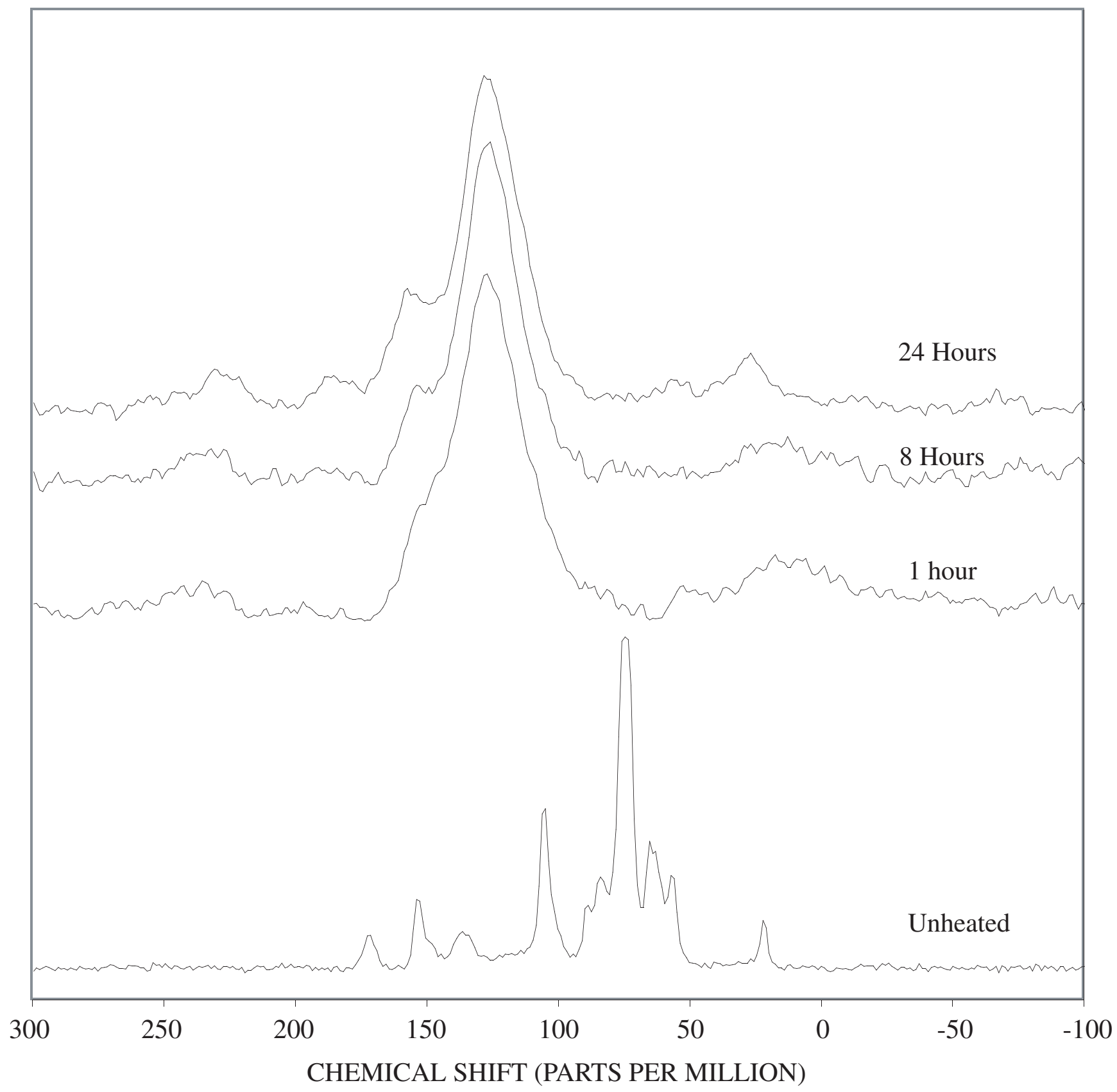

Figure C-13. ${ }^{13} \mathrm{C}$ Nuclear Magnetic Resonance (NMR) spectra of poplar wood heated at $350^{\circ} \mathrm{C}$ for various times. 


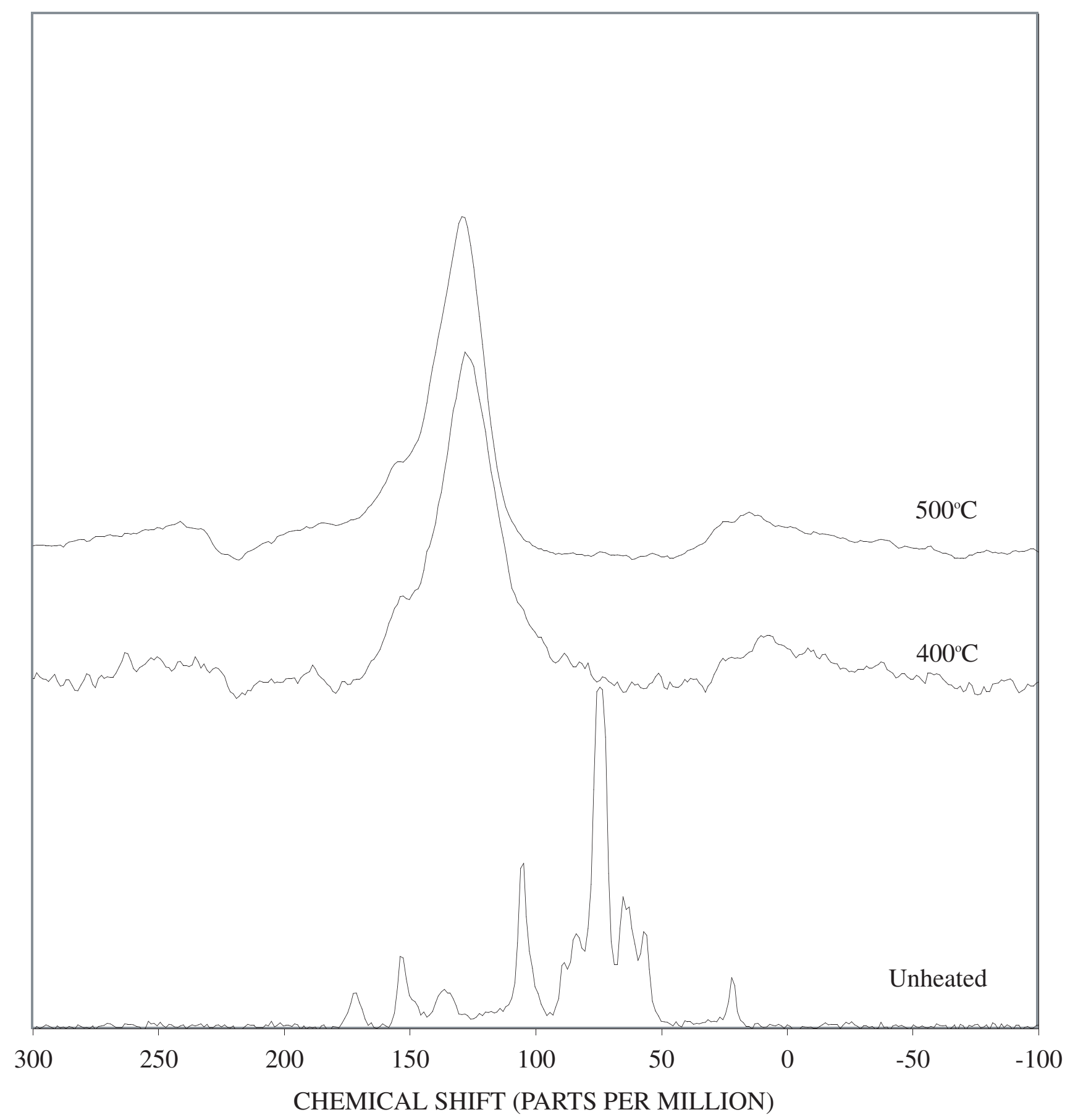

Figure C-14. ${ }^{13} \mathrm{C}$ Nuclear Magnetic Resonance (NMR) spectra of poplar wood heated at $400^{\circ} \mathrm{C}$ and $500^{\circ} \mathrm{C}$ for one hour. 


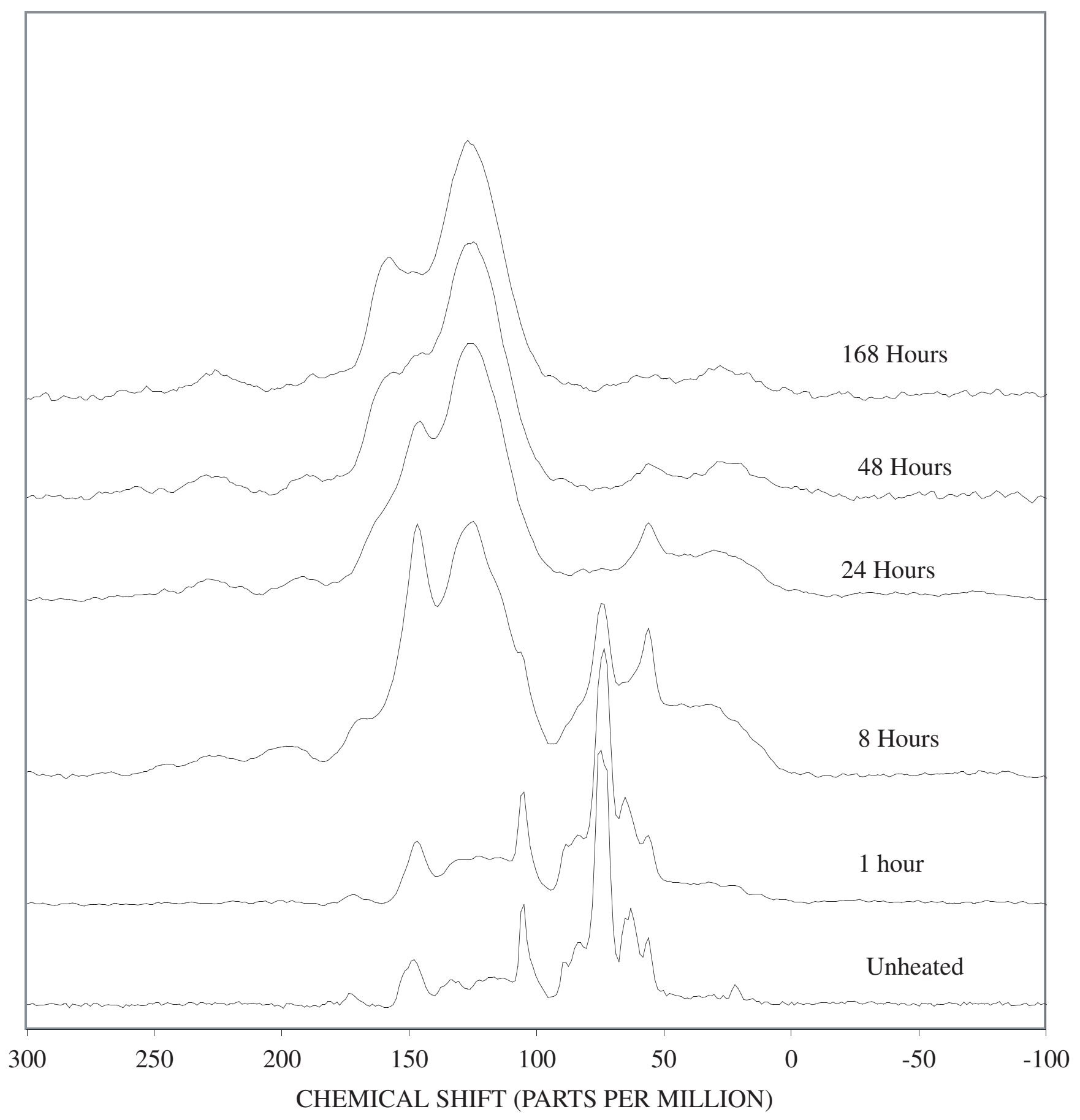

Figure C-15. $\quad{ }^{13} \mathrm{C}$ Nuclear Magnetic Resonance (NMR) spectra of pine wood heated at $250^{\circ} \mathrm{C}$ for various times. 


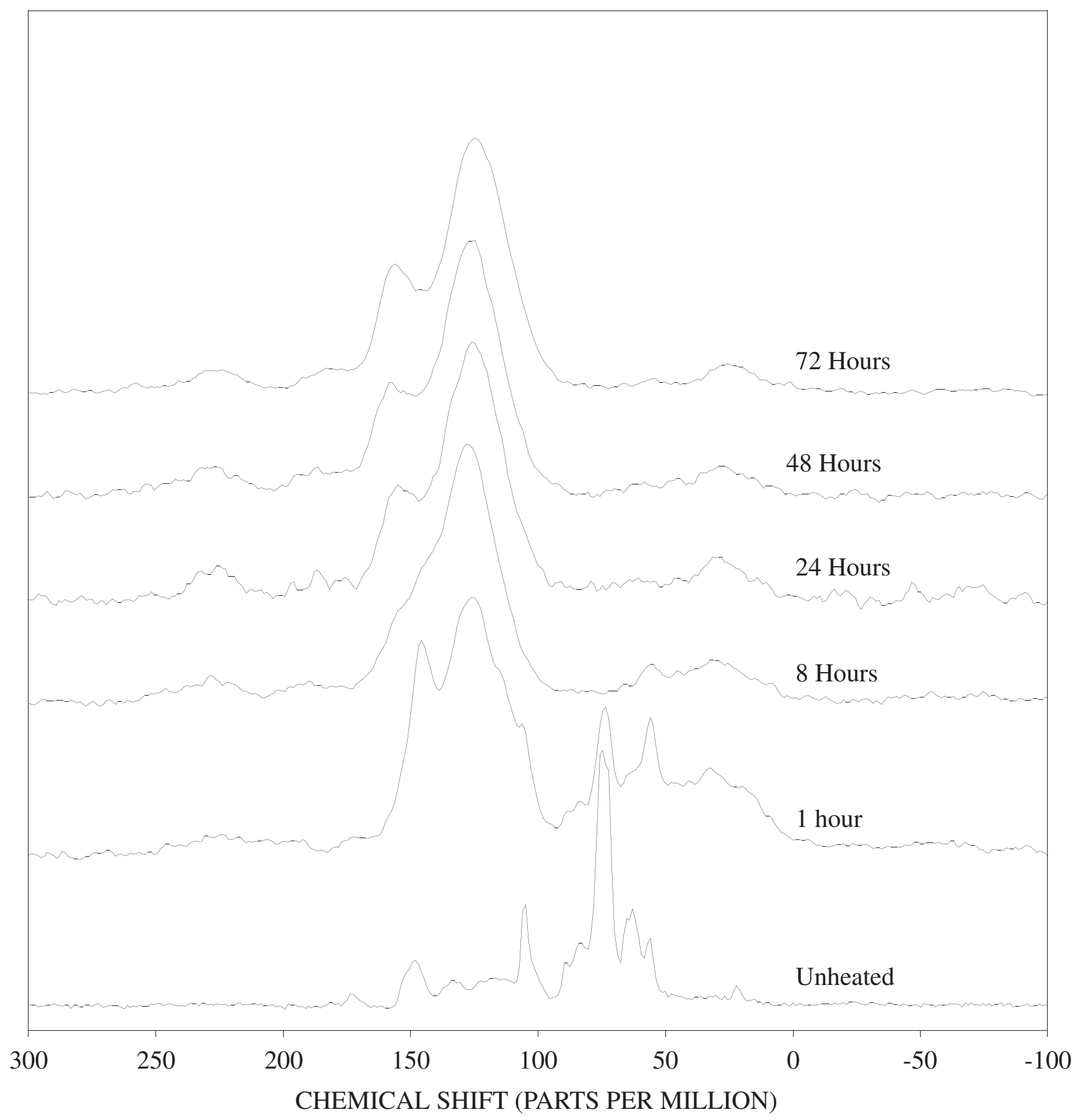

Figure C-16. ${ }^{13} \mathrm{C}$ Nuclear Magnetic Resonance (NMR) spectra of pine wood heated at $300^{\circ} \mathrm{C}$ for various times. 


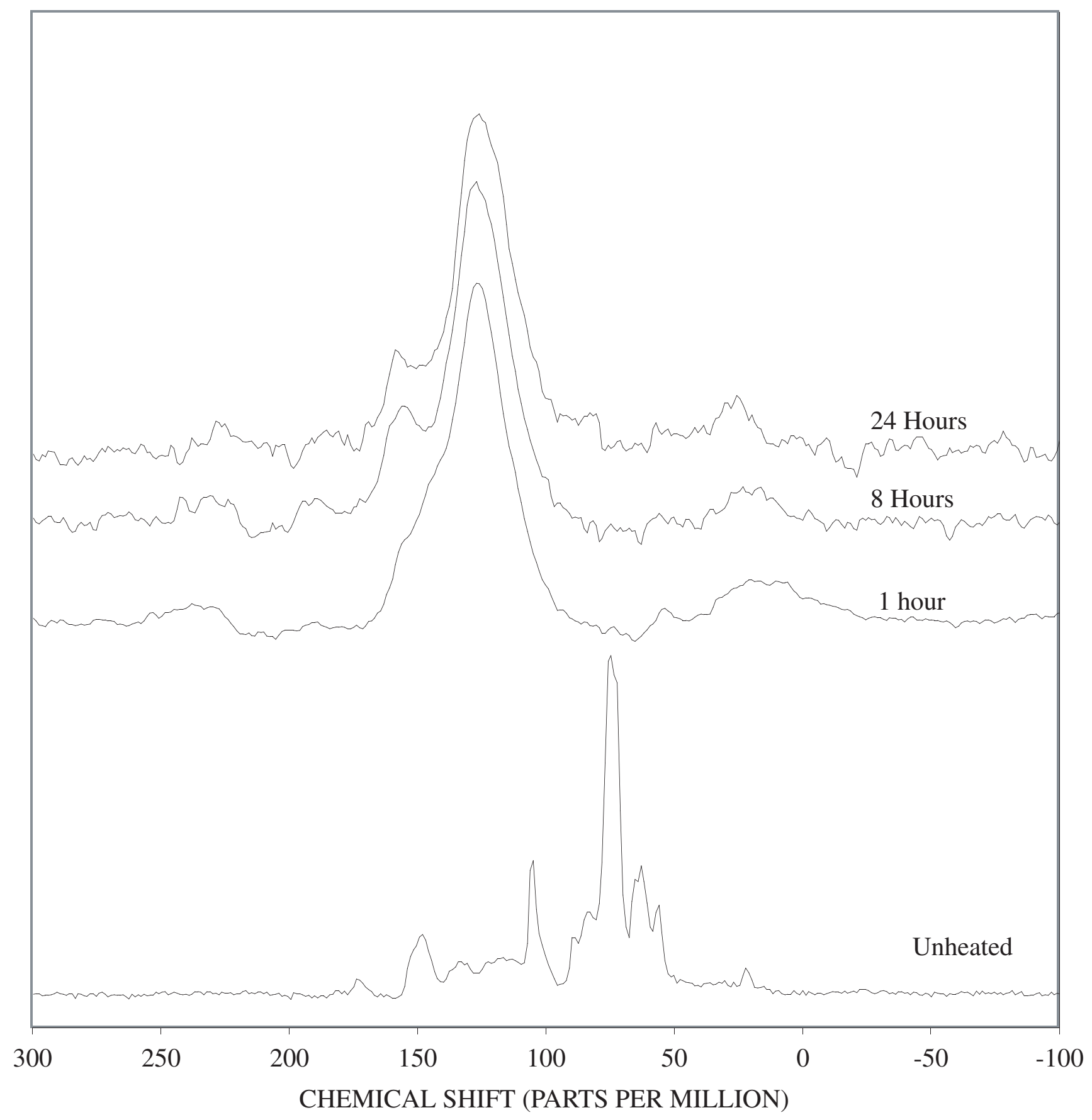

Figure C-17. ${ }^{13} \mathrm{C}$ Nuclear Magnetic Resonance (NMR) spectra of pine wood heated at $350^{\circ} \mathrm{C}$ for various times. 


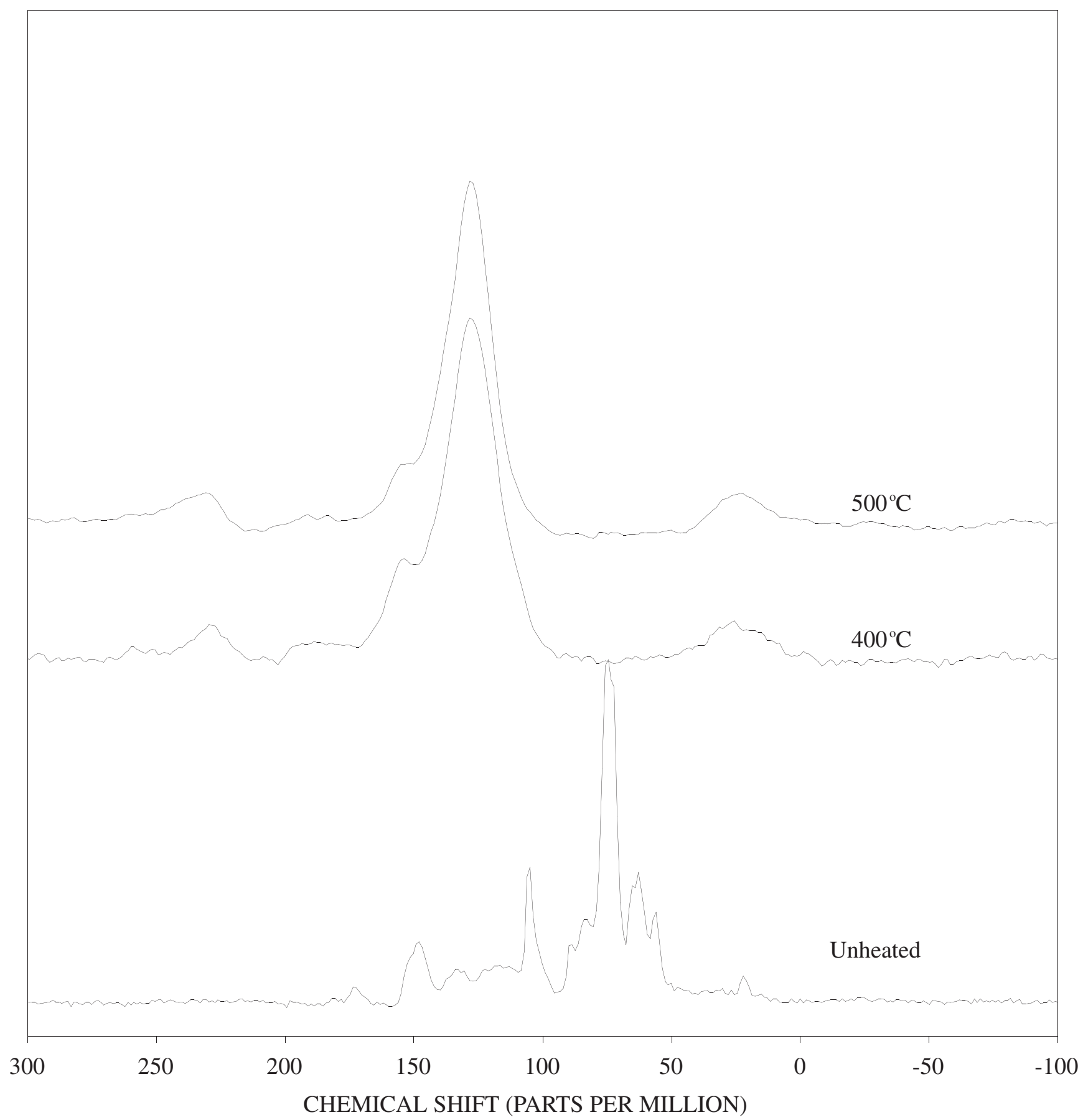

Figure C-18. ${ }^{13} \mathrm{C}$ Nuclear Magnetic Resonance (NMR) spectra of pine wood heated at $400^{\circ} \mathrm{C}$, and $500^{\circ} \mathrm{C}$ for one hour. 


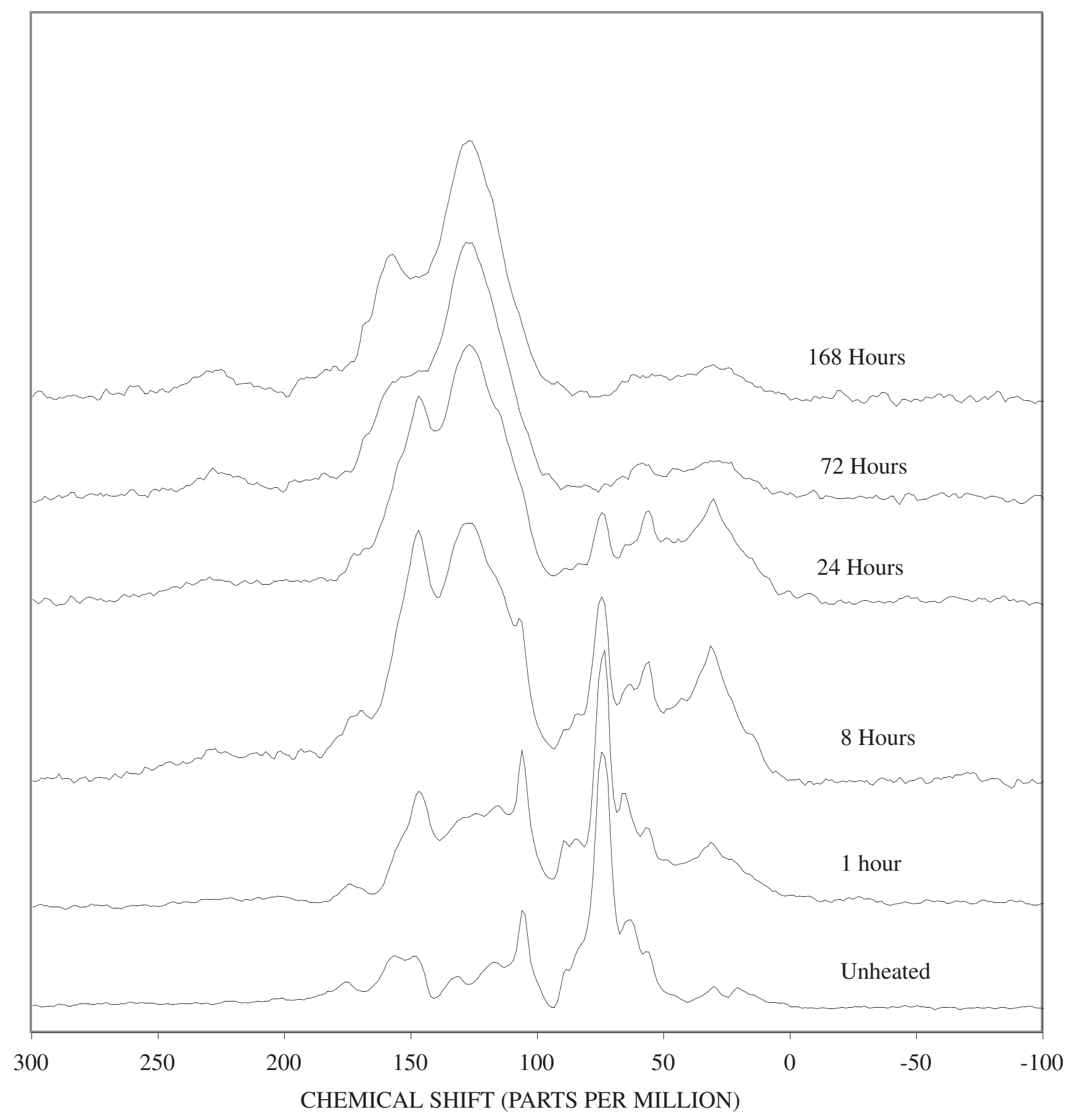

Figure C-19. ${ }^{13} \mathrm{C}$ Nuclear Magnetic Resonance (NMR) spectra of pine bark heated at $250^{\circ} \mathrm{C}$ for various times. 


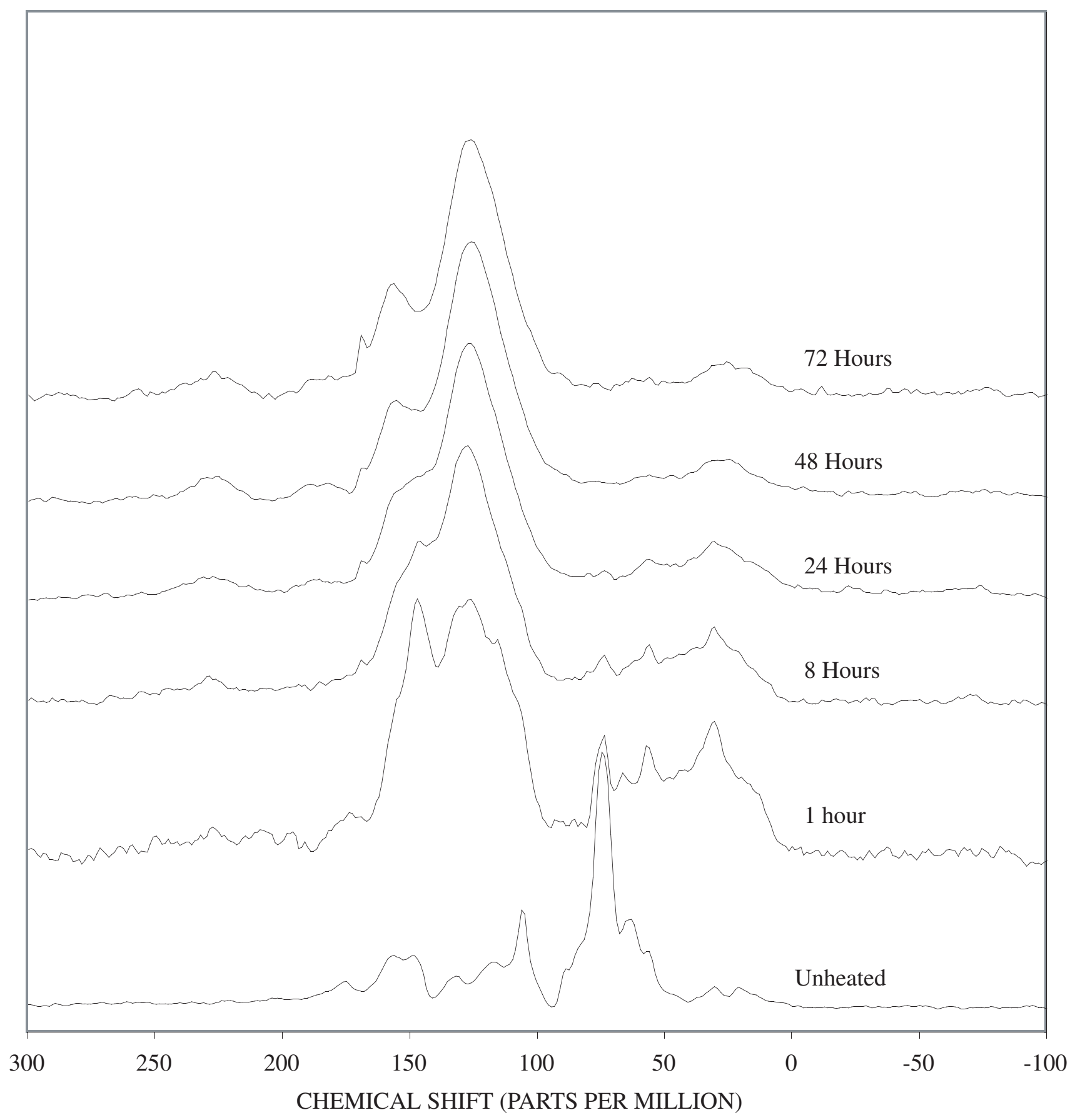

Figure C-20. $\quad{ }^{13} \mathrm{C}$ Nuclear Magnetic Resonance (NMR) spectra of pine bark heated at $300^{\circ} \mathrm{C}$ for various times. 


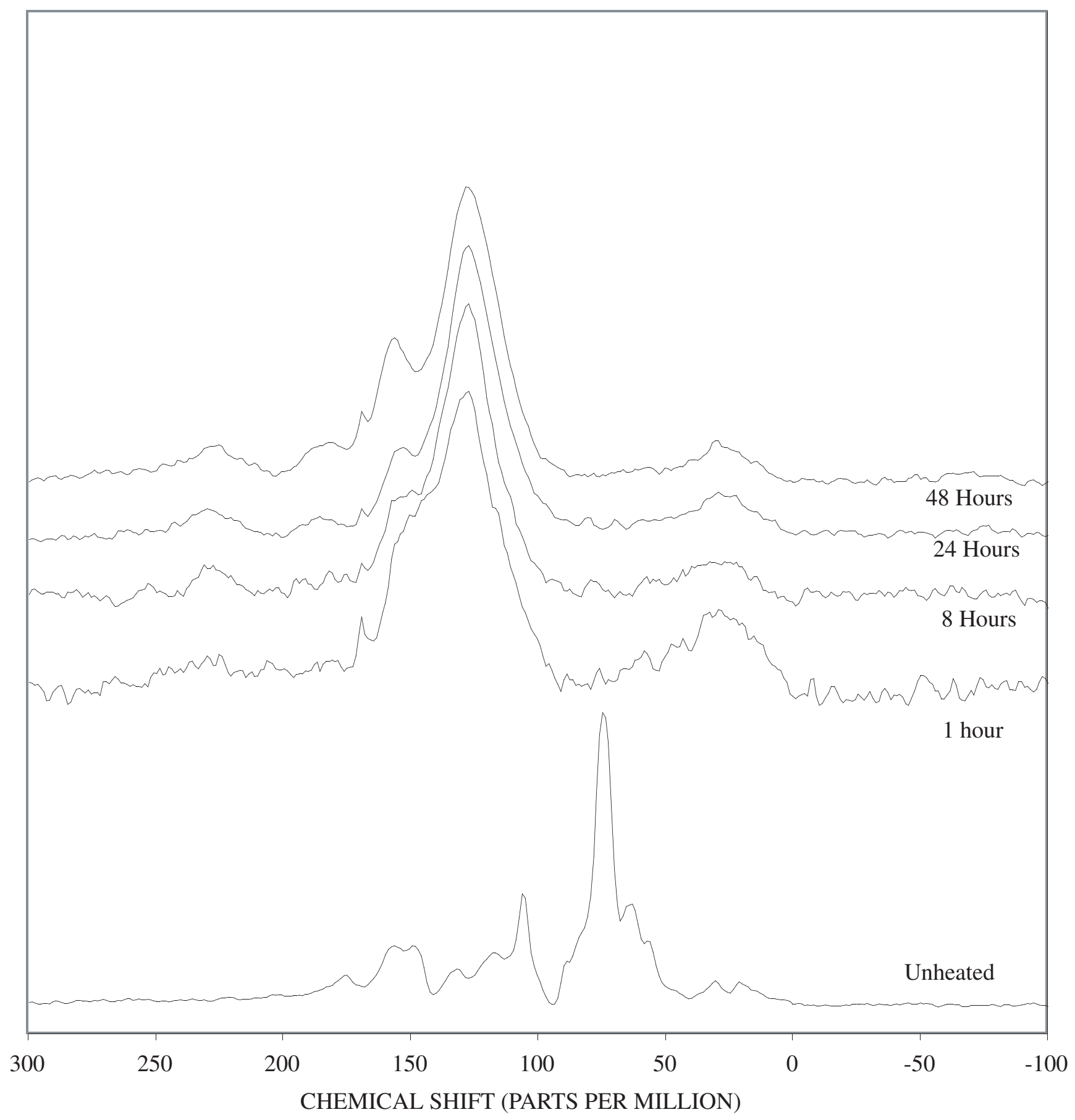

Figure C-21. ${ }^{13} \mathrm{C}$ Nuclear Magnetic Resonance (NMR) spectra of pine bark heated at $350^{\circ} \mathrm{C}$ for various times. 


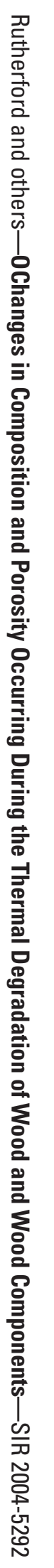

8 Printed on recycled paper 